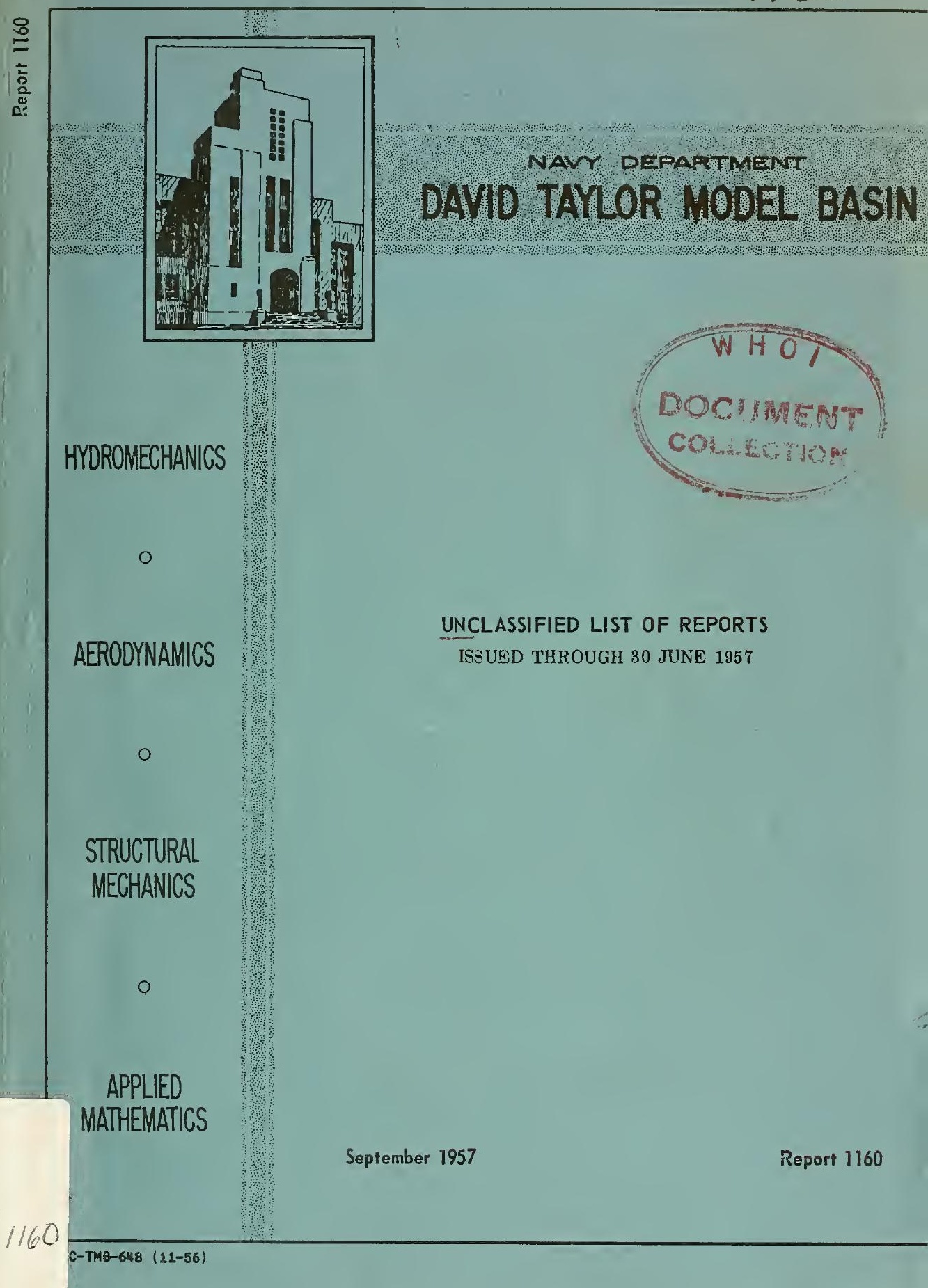




\section{UNCLASSIFIED LIST OF REPORTS}

ISSUED THROUGH 30 JUNE 1957 


\section{FOREWORD}

With this edition of the Unclassified List of Reports, the Model Basin is beginning a new system of publishing report information. Heretofore, the catalogs of Model Basin Reports have been kept up to date with supplements issued at irregular intervals.

The Model Basin now plans to issue quarterly loose-leaf supplements. These will be sent automatically to all who have a copy of this unclassified list.

This list is divided into four sections, each numbered separately, as I-1, II-1, III-1 and IV-1. Section I contains the regular series of TMB formal reports numbered consecutively without any preceding letter designation. Section II contains the R-series, which was discontinued in 1947. Reports in this series are designated as R-1, R-45, etc. Section III contains the $\mathrm{C}$-reports which have been declassified. These reports still carry the $\mathrm{C}$ designation preceding the number. Section IV contains the translations, which are numbered as T-1, T-25 and so forth.

Numbers listed without titles are either unpublished or not available for distribution. Missing numbers in the list are for classified reports not included in this list.

This first list, TMB Report 1160, supersedes TMB Report 597. Unlike Report 597 it no longer carries an author and subject index. 


\section{TABLE OF CONTENTS}

Page

REGULAR SERIES

R-SERIES

UNCLASSIFIED C-REPORTS

TRANSLATIONS
$I \cdot 1-I-81$

II $\cdot 1-I I-18$

III - 1 - III - 6

IV - 1 - IV $=28$ 
$\bullet$

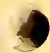


1. Report of the Pitching and Rolling Experiments on Battle Cruisers 1-6 (with and without Bilge Keels). Jan 1920. This is revised in Report 4.

2. Report of Test of Model No. 2234 with and without Ianding Wheels - Representing Twin Floats for $2450 \mathrm{Lb}$. Seaplane. Dec 1919. 8 pp., 6 figs. Distributed only upon authorization of Loening Aeronautical Engineering Corporation.

3. Report of Test of Model No. 2284 with and without Landing Wheels - Representing Twin Floats for $2570 \mathrm{Lb}$. Seaplane. Jan $1920.10 \mathrm{pp}$, 6 flgs. Distributed only upon authorization of Loening Aeronautical Engineering Corporation.

4. Revised Report of P1tching and Rolling Experiments on a Model of Battle Cruisers 1 to 6 , with and without Bilge Keels. Jan 1920.13 pp., 8 figs. This is a revision of Report 1.

5. Report of Test of Model No. 2269 (Three Types of Stern) - Representing Hull for Two-Place Flying Boat with C-R Engine. Jan 1920. 15 pp., 10 figs. Distributed only upon authorization of Curtiss Engineering Corporation.

6. Report of Rolling Experiments on a Model of United States Battleships 49-54 (with and without Bilge Keels). Mar 1920. 9 pp., 6 figs.

7. Report of Rolling Experiments on a Model of Express Passenger IIner for International Mercantile Marine Co., Wm. Francis Gibbs, N.A. (Model Tested with and without Bilge Keels). Mar 1920. 6 pp., 3 figs. Distributed only upon authorization of International Mercantile Marine Co.

8. Report of Rolling Experiments on a Model Representing U.S. Collier "JUPITER" Fitted As an Alrcraft Carrier. Mar 1920. 9 pp., 5 figs.

9. Report of Additional Tests of Model No. 2284 with Modifications - Representing Twin Floats for 2570-Lb. Seaplane. May 1920. 2 pp. Distributed only upon authorization of Loening Aeronautical Engineering Corporation.

10. The Measurement of Mast Vibration on the Tripod Mast during Gun Trials of the Brazilian Battleship "SÄO PAULO." May 1920. 8 pp., 3 figs.

11. Report of Test of Model No. 2294 Representing Hull of T.F. Flying Boat Modifjed to Carry M VII Torpedo (N.A.F. Blueprint \#53006). Jun 1920 . 7 pp., 4 figs.

12. Report of Test of Models No. 2239 \& 2293 Representing 2600 Lb. Seaplane with Arrow-Head Float. Jun 1920. $16 \mathrm{pp} ., 11 \mathrm{flgs}$.

13. Report of Rolling Experimënts on Model No. 2300 Representing U.S. Collier JUPITER Fitted As an Alrcraft Carrier. Jul 1920. 8 pp., 5 figs.

14. Report on the Frictional Resistance of Elaterite Marine Compound \#45-A Compared with Shellac and Varnish - Paint Submitted by Elaterite Products Corporation, by L.F. Hewins. Jul 1920. 4 pp., 1 fig.

15. Report of Tests on Model of EAGLE Class Patrol Boats to Determine the Inclining Moment of Wind at Various Velocities, by L.F. Hewins. Jul 1920. 5 pp., 3 figs.

16. Report of Experiment with Proposed Hulls of Giant Flying Boat - Orig1nal and Alternate Designs. Aug 1920. 12 pp., 6 figs. 
17. Report of Test of Vertical Steering Control of U.S. Submarine S-3, Using "Drowned" Bow Rudders with Guards, from Experiments with Model No. 1966. Aug 1920. 4 pp., 2 flgs.

18. Report of Rolling Experiments on Model No. 2300 Representing U.S. Aeroplane Carrier LANGLEY (Formerly U.S. Colller JUPITER). Sep 1920. 14 pp., 8 flgs.

19. Report of an Analysis of the Standardization Trials of Some Recent Destroyers. Sep 1920. $5 \mathrm{pp}$., $1 \mathrm{flg}$.

20. Report of Test of Vertical Steering Control of U.S. Submarines - BB-1 to $9(S-163-171)$ from Experiments with Model No. 2341. Sep 1920. 5 pp., 3 flgs.

21. Report of Experiments with Twin Floats for Loening M-81 Seaplane (Orig1nal and Modified Step Position). Nov 1920. 8 pp., 5 figs. Distributed only upon authorization of Loening Aeronautical Engineering Corporation.

22. Report of Experiments with Twin Floats for Curtiss C.T. Seaplane. Jan 1927. 8 pp., 5 figs. Distributed only upon authorization of Curtiss Engineering Corporation.

23. Report of Experiments with Twin Floats for Loening M-81 Seaplane (2nd and 3 rd Modifications Represented by Model 2346) (4th Modification Represented by Model 2371). Feb 1921. 13 pp., 8 figs. Distributed only upon authorization of Loening Aeronautical Engineering Corporation.

24. Preliminary Report of Resistance of Armor Bars and Gratings. Jan 1921. $14 \mathrm{pp}$., 4 figs.

25. Report of Experiments with Model 2374 - Hydrovane Wing T. Feb 1921. 2 pp., 1 fig.

26. Supplementary Report on Vertical Steering Control of U.S. Submarines S-163-171 from Experiments w1th Model No. 2341 . May 1921. 3 pp., 2 f1gs.

27. Report of Tests of a Merchant Type Model Fitted w1th a Regenerative Propeller of the "B1rkett" Type. Jun 1921. 4 pp., 2 flgs.

28. Report on the Comparison of Standardization Trial Data of 35-Knot Destroyers with Data Estimated from Results of Self-Propelled Models. Jun 1921. 16 pp., 10 f1gs.

29. Report on Test of Torpedo Forms. Jul 1921. 7 pp., 3 figs.

30. Report of Additional Tests w1th Twin Floats for Curt1ss C.T. Seaplane. Jul 1921. 7 pp., 5 flgs. Distributed only upon authorization of Curtiss Engineering Corporation.

31. Report of Experiments with Junker JI-6 Twin Floats. Jul 1921. 7 pp., 5 figs.

32. TS-1 Seaplane Floats (Twin) - Report of Experiments with Model\#2392. Sep 1921. 7 pp., 4 figs. 
33. Shipboard Fighter BS-1 - Report of Experiments with Model \#2381. Sep 1921. 7 pp., 5 figs.

34. Hydrovane Wing $\mathrm{T}$ - Report of Additional Experiments with Model \#2374. Sep 1921.4 pp., 2 figs.

35. Curtiss C.T. Seaplane Floats - Additional Experiments with Model No. 2350. Oct 1921. $6 \mathrm{pp} ., 4 \mathrm{flgs}$. Distributed only upon authorization of Curtiss Engineering Corporation.

36. D.T. Seaplane Floats - Report of Experiments with Model \#2394. Oct 1921. $7 \mathrm{pp} ., 5 \mathrm{flgs}$. Distributed only upon authorization of Davis-Douglas Co.

37. Test of Experimental Air Purifier. Nov 1921. 7 pp., 4 figs.

38. W.A. Seaplane Float - Report of Experiment with Model \#2393. Nov 1921. 6 pp., 4 figs.

39. Shipboard Fighter B.S.-1 - Experiments with Modifled Hull. Nov 1921. 7 pp., 5 figs.

40. W.A. Seaplane Float - Model \#2393 - Report on Additional Tests. Dec 1921. 7 pp., 5 flgs.

41. Report of Test of Vertical Steering Control of Ex-German Submarine U-111from Experiments with Model No. 2395. Jan 1922. 7 pp., 5 flgs.

42. Report of Further Tests on Experimental Air Purifier. May 1922. 12 pp., 7 flgs.

43. Spotting Seaplane Floats - Report of Experiments with Modol \#2426. May 1922. 7 pp., 5 flgs.

44. Marine Expeditionary Seaplane Floats - Report of Experiments with Model \#2420. May 1922. 7 pp., 5 f1gs.

45. Resistance of Disk Simulating Alrplane Engine in Four Foot Tunnel. May 1922. $7 \mathrm{pp} ., 3 \mathrm{figs}$. This Wind Tunnel report was erroneously included in the original Experimental Model Basin series of reports.

46. School Seaplane - Type T.G. - Report of Experiments with Model \#2430. May 1922. 7 pp., 5 figs.

47. Giant Flying Boat Hull - Report of Additional Experiments on Model \#2244. May 1922. 7 pp., 5 figs.

48. Canceled. See Report 63.

49. V.T. Seaplane Floats - Triple Arrangements - Report of Experiments with Models 2426 and 2440. Jul 1922.9 pp., 6 figs.

50. List of Models of Alrplane Floats and Flying Boats Tested in the Exper1mental Model Basin and Avallable Data. May 1922. $5 \mathrm{pp}$. (128 models tested.)

51. N.C. Series - Report of Experiments with Modifications of the Hull of the N.C. Flying Boat. Jul 1922. 72 pp., 66 flgs. 


\section{REGULAR SERIES}

52. Determination of Performance Characteristics of $1 / 4$-Horsepower Portable Ventllating set, Including the Determination of the Alr-Carrying Properties of Canvas Hose. Jul 1922. 6 pp., 2 f1gs.

53. Thornycroft Skimmer - Experiments with Model 2347 As a Seaplane Float. Jul 1922. 7 pp., 5 flgs.

54. The U.S. Experimental Model Basin. Jul 1922. 7 pp.

55. Determination of the Amount of Resistance to the Flow of Alr offered by Armor Gratings, When Used in Conjunction w1th Expansions and Contractions of Duct: Resistance offered by 12 Inch $x 5$ Inch Ventur1 Tube. Aug 1922. 26 pp., 16 flgs.

56. Resistance of Standard Wire Mesh Basket for Ventilation Terminals: Resistance of Wire Screen Cloth. Aug 1922. $14 \mathrm{pp}, 7 \mathrm{f1gs.}$

57. Report on Test of Surface Propellers. Aug 1922. 16 pp., 12 figs.

58. Resistance of Granular Charcoal to the Flow of Alr. Aug 1922. 10 pp., $5 \mathrm{flgs}$.

59. VT Twin Floats - Report on Experiments with the Original Design and Mod1fications 1-4 Inclusive. Aug 1922. $18 \mathrm{pp} ., 14 \mathrm{flgs}$.

60. VE-7 Seaplane Float - Report of Experiments w1th Model 2424. Sep 1922. 8 pp., 6 flgs.

61. Some Experiments on Propeller Positions and Propulsive Efficiency, by D.W. Taylor, Rear Admiral, USN. Sep 1922. 16 pp., 10 flgs.

62. River Gun Boat. Nov 1922. No complete report avallable.

63. Stab1lity Tests - Experiments with Models of Seaplane Floats and Flying Boats. Nov 1922. 13 pp., 12 figs.

64. Report of Test of Vertical steering Control of Model of German Submarines $\mathrm{U}-181-190$. Dec 1922. 5 pp., 3 figs.

65. VT Twin Floats - 5th \& 6th Modifications - Report of Experiments with Models 2457 \& 2458. Dec 1922. 13 pp., 9 flgs.

66. Report of Tests of Propellers on Self Propelled Model of U.S.S. DELAWARE. Dec 1922. $10 \mathrm{pp} ., 8 \mathrm{flgs}$. Distributed only upon authorization of N.W. Akimoff.

67. U0-1 Seaplane Float - Report on Experiments w1th Models 2455 and 2456. Dec 1922. 11 pp., 9 figs.

68. TS-1 Seaplane Floats (Twin) - Report of Additional Experiments with Model No. 2392. Jan 1923. $10 \mathrm{pp}$., $6 \mathrm{flgs.}$

69. Report of Rolling Experiments on Model No. 2375 - Representing U.S. Crane Sh1p No. 1. Mar 1923. 12 pp., 7 figs. 
70. F-5-L Flying Boat Hull (E.M.B. Model \#2171) - Report of Experiments to Determine Effect of Changing Position of Rear Step. Mar 1923. 8 pp., 6 figs.

71. Towing of Vessels at Sea. Apr 1923. 6 pp., $1 \mathrm{fig}$.

72. NM-1 Twin Floats - Report of Experiments with Model \#2485. Apr 1923. 8 pp., 6 flgs.

73. Increase in Frictional Resistance of Ships Due to Lapped Butts. Mar 1923. $4 \mathrm{pp}$., $1 \mathrm{fig}$.

74. Results of Tests of a Model of the Proposed Floating Dry Dock. Apr 1923. $21 \mathrm{pp} ., 17 \mathrm{figs}$.

75. U0-1 Seaplane Float - Report of Experiments with Model \#2492. Apr 1923. 9 pp., 6 figs.

76. Experiments with Models of VT-Twin Floats, Modification \#1 and VT-Triple Float, Arrangement \#2. Apr 1923. 11 pp., 8 flgs.

77. Catapult Test, Ordnance Des1gn, Shots 1-2-3-4. Mar 1923. $10 \mathrm{pp}, 4$ f1gs.

78. Catapult Test, Ordnance Design, Shots Nos. 1 to 13 Inc. Apr 1923. 36 pp., $8 \mathrm{flgs}$.

79. Preliminary Design No. 25 - Hulls Nos. 1 and 2 - Report of Experiments w1th Model \#2497. May 1923. 10 pp., $6 \mathrm{flgs.}$

80. VT Twin Float Model \#2426 - Experiments with and without Hydrovanes. May 1923. 13 pp., 10 flgs.

81. VT Twin Floats - Modfications \#7 and\#8 - Experiments w1th Model No. 2493. Jun 1923. 9 pp., 5 flgs.

82. Result of Tests of Models of a Shallow Draft River Gunboat. Jul 1923. 31 pp., 25 flgs.

83. Kirsten-Boeing Propeller. Oct 1923.

Letter report on TMB file QN/Kirsten-Boeing Company. Oct 1923, Vol. 2. For Official Use Only.

84. DT Seaplane Floats - Results of Experiments with Modified Lines. Nov 1923. $11 \mathrm{pp} ., 6$ flgs.

85. NW Seaplane - Mk I Floats - Experiments w1th Model\#2495. Nov 1923. 8 pp., 6 flgs.

86. Report of Test of Vertical Steering Control of Cruiser Submarine from Experiments w1th Model No. 2517 . Der 1923. 8 pp., 6 figs.

87. Class VS Seaplanes for Small Vessels - Twin Floats Mark I \& Mark II E.M.B. Models 2500 \& 2514. Dec 1923. 14 pp., 9 flgs.

88. TS Seaplane - Experiments with Model of Mk II Twin Floats (E.M.B. Model * 2494). Dec 1923. 8 pp., 6 f1gs. 89. PN-7 Flying Boat Hull - Experiments with Model No. 2527. Dec 1923. 9 pp.,
5 flgs. 
90. P-5-A Flying Boat Hull - Experiments with Model No. 2525. Jan 1924. 10 pp., 6 figs.

91. Test of Venturi Tube on Ventilation Terminal. Mar 1924. 9 pp., 5 figs.

92. Vanderbilt Flying Boat - Report of Experiments with E.M.B. Model No. 2546. Mar 1924. 9 pp., 6 figs. Distributed only upon authorization of Kirkham Products Corporation.

93. Bu. Aer. Three Seater Spotting Seaplane (Project No. 1047) - Report of Experiments with Model \#2587. Sep 1924. 9 pp., 6 figs. Distributed only upon authorization of Burealu of Aeronautics.

94. Loening 3-Seater Amphibian F.B. Hull (Bu. Project No. 1046) - Report of Experiments with Model \#2586. Sep 1924. 9 pp., 6 figs. Distributed only upon authorization of Loening Aeronautical Engineering Corporation.

95. Composite N.C. Lines - PN Type (Bu. Aer. PI. \#3157 - Project\#1018) Report on Experiments with Model\#2577. Sep 1924. 9 pp., 6 figs. Distributed only upon authorization of Bureau of Aeronautics.

96. Test of Ventilating Set Furnished by the Robinson Ventilating Company. Sep 1924. 6 pp., 4 figs.

97. Bu. Aeronautics Design \#28 - Report of Experiments with Model\#2548. Sep 1924. $10 \mathrm{pp}$., $6 \mathrm{figs}$. Distributed only upon authorization of Bureau of Aeronautics.

98. F-5-L Hull Modified - Additional Experiments with Model No. 2171. Sep 1924. 10 pp., 6 figs.

99. PN-7 Hull - Overland Tests - Model No. 2527 - Stern No. 1. Sep 1924. 9 pp., 5 figs.

100. TS-7 Twin Floats - N.A.F. Iines \#51863 - Experiments with Model\#2547. Sep 1924. $8 \mathrm{pp} ., 6 \mathrm{figs}$.

101. Report of Test of Vertical Steering Control of Model Representing Mine Laying Submarine SM-1. Oct 1924. 5 pp., 3 figs.

102. Mummert Flying Boat Hull - Report of Experiments with Model No. 2600. oct 1924. 7 pp., 4 figs. Distributed only upon authorization of H.c. Mumert.

103. DT Twin Floats - Report of Additional Experiments with Model\#2394. Nov 1924. 9 pp., 5 figs. Distributed only upon authorization of Davis-Douglas Co.

104. Boeing Patrol Plane - HulI - Report of Experiments with Model No. 2597. Nov 1924. 10 pp., 6 flgs. Distributed only upon authorization of Boeing Airplane Company.

105. UO- 1 Seaplane Float - Model No. 2492; N9H Seaplane Float - Model No. 2584 - Experiments to Determine Forces and Moments at Landing Angles, Also Usual Towing Tests with the N9H Model. Nov 1924. 13 pp., 8 figs.

106. Model Experiments to Determine Rudder Forces - NEW MEXICO. Dec 1924. 34 pp., 27 figs.

107. Mummert Flying Boat Hull - Additional Experiments with Model No. 2600 Modified. Dec 1924. 9 pp., 5 figs. Distributed only upon authorization of H.C. Mumert. 
108. Flettner Wind Rotors for Ship Propulsion (Estimate of Propulsive Forces Obtainable). Dec 1924. 8 pp., 2 figs.

109. Report of Test on Model of U.S.S. LANGLEY to Determine Leeway Due to W1nd. Jan 1925. 6 pp., 2 flgs.

110. Report on the Extent of Cavitation in U.S. Scouts \& Destroyers. Jan 1925. $9 \mathrm{pp} ., 1 \mathrm{flg}$.

111. Bu. Aer. Des1gn No. 31 - Hull - Report on Experiments w1th Model No. 2588. Jan 1925. 11 pp., 6 flgs.

112. Report of Test of Vertical Steering Control of U.S. Submarines R-1 to R-20 from Experiments w1th Model No. 2450 . Feb 1925. 5 pp., 3 figs.

113. Test Float with Variable Keel Angle - Report on Experiments w1th Model \#2602. Mar 1925. 11 pp., 5 f1gs.

114. An Analys1s of a Fa1lure of Keel Blocks in a Dry Dock, by Lt. Comdr. E.L. Gayhart, USN. May 1925. $37 \mathrm{pp} ., 13 \mathrm{flgs.}$

115. Report of Test of Vert1cal Steering Control of Model Representing Fleet Submarine, Mine Laying Type with Alterations. May 1925. 5 pp., 3 figs.

116. The Calibration and Test of a Redes1gned Sperry Roll and P1tch Recorder. Jul 1925. $18 \mathrm{pp}$., 9 flgs.

117. Notes on the Des1gn and Propulsion of the 8-Oared Shell. Aug 1925. 17 pp., 7 figs.

118. A Description of the U.S. Experimental Model Basin. Sep 1925. 14 pp., 6 figs.

119. Ventilation Tests. Oct 1925. 8 pp. Supplement. Feb 1926. 28 pp., 21 flgs.

120. Boe1ng Patrol Plane - Report of Additional Experiments with Model No. 2597. Nov 1925. 9 pp., 6 figs. Distributed only upon authorization of Boeing Airplane Company.

121. Stability Model - U.S.S. CALIFORNIA. Nov 1925. 7 pp., 2 f1gs.

122. Electrical Telemeter - Principle of Operation and Notes on Methods of Use. Jan 1926. 7 pp., 3 flgs.

123. S.C. Type Amphiblan Floats - Report on Experiments w1th Model No. 2650. Jan 1926. 9 pp., 5 flgs.

124. DT-2 Seaplane Floats - Concave Bottom Modifications - Report on Exper1ments with Model \#2622. Jan 1926. 8 pp., 4 f1gs.

125. Tests of a Model of a High Speed Towing Target. Feb 1926. 10 pp., 4 f1gs.

126. End Speed Meter for an A1rplane Catapult. Mar 1926. 8 pp., 3 f1gs.

127. S.C. Type Amphibian Floats (Modifled L1nes) - Report on Experiments with Model \#2661. Mar 1926. 9 pp., 5 flgs. 
128. Test of Vertical Steering Control of Model Representing U.S. Submarines $\mathrm{V}-5$ and V-6. Apr 1926. 7 pp., 4 figs.

129. DT-2 and SC-1 Tw1n Floats (Models Nos. 2394 and 2426) - Stab1l1ty Tests with Flooded Compartments. Apr 1926. 6 pp., 4 flgs.

130. Report of Test of Vertical Steering Control of Model No. 2449 Representing U.S. Submarines V-1 to V-3 with Modifled Bow, As per $C$ and $R$ Sketch 08662. Apr 1926. 2 pp., 1 fig.

131. Racer Type Seaplane Floats - Report on Experiments w1th Models of. Jun 1926. 20 pp., 14 flgs.

132. The Est1mate of Power for ShIp Propulsion and the Methods Employed at the Experimental Model Basin, by Comdr. E.L. Gayhart, USN. Jun 1926. $37 \mathrm{pp}$., 17 flgs.

133. Design No. 38 - Class VF Seaplane Float - Experiments with Model No. 2665. Jun 1926. 9 pp., 6 flgs.

134. Consolidated Training Plane Float - Modifled Lines - Report of Experiments with Model No. 2660. Jun 1926. 8 pp., 5 flgs.

135. V.T. Float Series - No. 9 Floats - Experiments with Model No. 2652. Jun 1926. 8 pp., 5 figs.

136. T3M - Amphibian Floats - Experiment with Model of. Jul 1926. 10 pp., 5 rigs.

137. Design No. 51, Class VT Seaplane Floats - Experiments with a Model of. Jul 1926. 8 pp., 5 flgs.

138. Design No. 50 - Class.VP Flying Boat Hull - Experiments with a Model of. Jul 1926. 10 pp., 6 figs.

139. Design No. 47 Hull (Bu. Aer. Pl. No. 3944 - Project No. 1403) - Exper1ments with a Model of. Jul 1926. 10 pp., 7 flgs. Distributed only upon authorization of Bureau of Aeronautics.

140. Analys $1 \mathrm{~s}$ of the Standardization Trlals of the U.S. Battleships MARYLAND, WEST VIRGINIA, and COLORADO, by Capt. W1111am MCEntee, USN. Aug 1926. 15 pp., 3 rigs.

141. T3M Amphibian Floats - Add1tional Experiments w1th Modifled Model. Aug 1926. 10 pp., 6 flgs.

142. Experiments with Model 2696 Representing 5000-Pound Single Float. Sep 1926. 9 pp., 6 flgs.

143. Des1gn No. 58 - Class VF Seaplane - Mark I and II Floats - Experiments with a Model of. Oct 1926. 11 pp., 7 figs.

144. Design-No. 58 - VF Seaplane sloat - Experiments with Model of. Oct 1926. 11 pp., 5 flgs.

145. Exper1ments with Edo A1rcraft Corp. Models "Malolo" \& "Turtle." Oct 1926. 11 pp., $6 \mathrm{flgs}$. Distributed only upon authorization of Edo Aircraft corporation. 


\section{REGULAR SERIES}

146. T.S. Type Seaplane Floats - Experiments with Models of. Oct 1926. 18 pp., 13 figs.

147. The Effect of Differences of Trim upon the Propulsive Coefficlent of a Vessel. Nov 1926. $10 \mathrm{pp}$., 5 fligs.

148. H.A. Type Seaplane Float - Experiments with Model of. Nov 1926. 9 pp., 6 figs.

149. Vent1lation Tests - Res1stance of Elbows. Nov 1926. $8 \mathrm{pp}, 4 \mathrm{flgs}$.

150. Design No. 42 - Experiments with a Model of the Hull. Dec 1926. 9 pp., 6 figs.

151. H.A. Berliner Float Models - Model Basin Tests. Dec 1926. 13 pp., 7 flgs.

152. T3M Single Float, \#3 Lines - Flat NC Type. Jan 1927. 10 pp., 6 figs.

153. Tests of High Speed-Displacement Boats - Experiments to Determine the Feasiblilty of Testing with Gear 3. Jan 1927. 6 pp., 2 flgs.

154. Loening Single Wheel Amphibian OA-2 - Experiments w1th a Model of. Jan 1927. $9 \mathrm{pp} ., 6 \mathrm{flgs}$. Distributed only upon authorization of Loening Aeronautical Engineering Corporation.

155. Fokker Float Wing - Experinents with a Node? of. Feb 19̧7. 10 pp., $6 \mathrm{flgs}$. Distributed only upon authorization of Atlantic Aircraft Corporation.

156. NB-1 Seaplane Float - Experiments w1th a Model of. Feb 1927. 8 pp., 5 flgs.

157. Bu. Aeronaut1es Design No. 28, Modifled - Experiments with Model of. Feb 1927. 11 pp., 6 figs.

158. Design No. 30, Amphibian Floats - Experiments with Model of. Feb 1927. 10 pp., 6 flgs.

159. Boeing Amphiblan Hull - Experiments with a Model of. Feb 1927. 9 pp., 7 flgs. Distributed only upon authorization of Booing Airplane Company.

160. Reaction on Float Bottom When Making Contact with Water at High Speeds. Feb 1927. 5 pp., 3 flgs.

161. Design No. 59, Flying Boat Hull - Experiments with a Model of. Apr 1927. 10 pp., 7 flgs.

162. Macch1 Racing Floats, 1926 - Experiments with a Model of. Apr 1927. 9 pp., 5 figs.

163. Modifled 1926 Racing Floats - Experiments w1th a Model of. Apr 1927. 9 pp., 5 flgs.

164. Loening Single-Wheel Amph1b1an OA-2, Modifled - Experiments with a ModeI of. May 1927. $14 \mathrm{pp}$., 9 flgs. Distributed only upon authorization of Loening Aeronautical Engineering Corporation.

165. Experiments with Edo Aircraft Corporation Models GUNARD and FLOAT E. May 1927. 9 pp., 5 figs. Distributed only upon authorization of Edo Aircraft Corporation. 
166. Description of the Nine Inch Wind Tunnel Bullt by the Construction and Repair Department of the Washington Navy Yard for the Bureau of Aeronautics for Use at the U.S. Naval Academy. May 1927. 16 pp., $7 \mathrm{flgs.}$

167. Self Propelled Model Test of Tunnel Towboat "NATCHEZ." May 1927. 3 pp. Supplementary Tests with the Model of S.S. NATCHEZ. Aug 1927. $16 \mathrm{pp}$., 13 figs. Distributed only upon authorization of Inland Paterways Corporation.

168. S.C. Type Amphibian Floats, Mark II Lines - Experiments with a Model of. May 1927. 10 pp., 5 figs.

169. 1926 Racing Floats 2nd Modification - Experiments with a Model of. Jun 1927. 9 pp., 5 flgs.

170. Experiments to Note the Effect of Varying the Depth of the step on a Seaplane Float. Jul 1927. 18 pp., 12 figs.

171. Design No. 67 'Hull - Experiments with a Model of. Jul 1927. 9 pp., 6 figs.

172. Charles Ward Hall T3M Amphibian Floats - Experiments with a Model of. Aug 1927. 12 pp., 7 figs.

173. Design No. 63 Float - Class VF Seaplane - Experiments with a Model of. Aug 1927. 8 pp., 5 flgs.

174. Brewster Floats for Model 74 - Experiments with a Model of. Aug 1927. 9 pp., 5 figs. Distributed only upon authorization of Brewster and Company.

175. T2D-1 Seaplane Floats - Brewster Model - Model Basin Experiment. Aug 1927. 9 pp., 5 figs.

176. Model Tests with Paddlewheels - Undertaken for the office of the Chief of Englneers, U.S. Army, by K.E. Schoenherr. Sep 1927. 18 pp., 13 f1gs.

177. Design No. 71 Hull Lines, Class V.P. Flying Boat Hull (Project No. 1677). Oct 1927. 11 pp., 8 figs. Distributed only upon authorization of Buraeu of Aaronautics.

178. Fa1rchild Twin Floats - Experiments with Models of. Oct 1927. 11 pp., 6 figs. Distributad only upon authorization of Fairchild Airplane Manufacturing Corporation.

179. Williams Racer Floats (Bu. Aeronautics Project No. 1746) - Experiments with a Model of. Oct 1927. $10 \mathrm{pp}, 6 \mathrm{flgs}$. Distributed only upon authorization of Burbau of Aeronautics.

180. Brewster Single Float B-301 Model Tests (Bu. Aer. Project 1743). Nov 1927. 9 pp., 6 flgs. Dlatributed only upon authorization of Brewater and Company.

181. F7C-1 Seaplane Float - Bu. Aer. Project No. 1673 - Experiments with Model of. Nov 1927. $10 \mathrm{pp},, 6 \mathrm{flgs}$. Dlatributed only upon authorization of Bursau of Aeronautics.

182. Design No. 71 Hull, Class VF Flying Boat - Additional Test with Alternate step (Project No. 1677). Dec 1927. 9 pp., 6 figs. Diatributad only upon authorization of Burgau of Aeronautics. 
183. Aeroplane Design No. 54 - Bureau of Aeronautics Launching Tests. Nov 1927. 7 pp., 3 figs.

184. T2D-1 Seaplane Floats - Brewster \& Co. Model - Additional Experiments. Dec 1927. 5 pp., 2 figs. Distributed only upon authorization of Brewster and Company.

185. Design No. 51 Seaplane Floats - Stability Tests with Damaged Compartments. Dec 1927. 5 pp., 2 figs.

186. O2U Amphibian Float (Bu. Aero. Project No. 1774) - Experiments with a Model of. Jan 1928. 10 pp., 6 figs. Distributed only upon authorization of Bureau of Aeronautics.

187. Report on Comparative Propeller Tests, Made in English, German and U.S. Model Basins. Jan 1928. 27 pp., 6 figs.

188. PN-7 Hull - Shoal Water Tests - Bureau of Aeronautics Project No. 1517. Mar 1928. 9 pp., 1 fig. Distributed only upon authorization of Bureau of Aeronautics.

189. Resistance of Ships in Canal Locks. Mar 1928. 9 pp., 1 fig.

190. Ventilation Tests on Ventilating Deadlights. Mar 1928. 20 pp., 11 figs.

191. Miller Corporation Amphibian Hull, Experiments with a Model of - Model 2835. Apr 1928. Distributed only upon authorization of Miller Corporation.

192. PN-7 Hull - Additional Shoal Water Tests (Width of Channel Unrestricted) Bureau of Aeronautics Project No. 1829. May 1928. 10 pp., 6 figs. Distributed only upon authorization of Bureau of Aeronautics.

193. Frictional Resistance. May 1928. 21 pp., 5 figs.

194. Self-Propelled Model Tests with Mississipp1 River Towboats and Barges. May 1928. $161 \mathrm{pp}$, , $141 \mathrm{figs}$. Distributed only upon authorization of Vesta Coai Company. (Now Jones - McLaughlin Steel Co.)

195. 02U-1 Floats with Sponsons (Bureau Aero. Project\#1777) - Model Experiments. May 1928. 11 pp., 7 figs. Distributed only upon authorization of Bureau of Aeroneutics.

196. Design No. 70 Seaplane Float - Model Tests - Bureau Aeronautics Project No. 1770. May 1928. $12 \mathrm{pp}$., 8 figs. Distributed only upon authorization of Bureau of Aeronautics.

197. Sport Flying Boat Hull, Skyways Inc., Boston (E.M.B. Model No. 2845). Jul 1928. $9 \mathrm{pp}$, $5 \mathrm{figs}$. Distributed only upon authorization of Skyways Inc.

198. Tests of Ventilation Terminals (Ezyreg and McCreery Elbows). Aug 1928. 9 pp., 4 figs.

199. Wind Deflection from the Open Windows of a Destroyer Pilot House. Aug 1928. 20 pp., 4 figs.

200. Test of Ventilation Terminals (Punkah Louvres). Sep 1928. 11 pp., 6 figs. 201. Racer Floats - Model Tests - Bu. Aer. Project No. 1874. Oct 1928. 14 pp., 9 figs. Distributed only upon authorization of Bureau of Aeronautics. 


\section{REGULAR SERIES}

202. XPH-1 Flying Boat Hull - Model Tests - Bu. Aeronautics Project No. 1846. oct 1928. 10 pp., 6 flgs. D1stributed only upon authorization of Bureau of Aeronautics.

203. Model Experiments with Seaplane Floats with Varying $L / B$ and $B / \sqrt{W}(B=$ beam; $\mathrm{L}=\mathrm{LWL}$ length; $W=$ normal displ. In $1 \mathrm{bs}$ ) - Bu. Aeronautics Project No. 1810. Oct 1928. 17 pp., 12 figs. Distributed only upon authorization of Bureau of Aeronautics.

204. Experimental Class VF Float - Model Tests - Bu. Aero. Plan No. 4447 Project No. 1739. Oct 1928.10 pp., 6 figs. Distributed only upon authorization of Bureau of Aeronaut1cs.

205. Tests of Toncan-Molybdenum Iron from Central Alloy Steel (Incorporated). Sep 1928. 8 pp., 4 flgs. Distributed only upon authorization of Central Alloy Stsel Corp.

206. 60-Inch Turret Stool Models Nos. 1-3 and 10-Inch Model No. 13. Oct 1928. 59 pp., 34 rigs.

207. Design of Turret Foundations. Oct 1928. 24 pp., 3 figs.

208. Mercury Racer Floats - MK. I. IInes (Bureau of Aeronautics Project \#1874). Nov 19?8. 10 pp., 7 figs. Distributed only upon authorization of Bureau of Aeronautics.

209. Keystone Aircraft Corporation, Bristol, Pa. - Flying Boat Hull. Nov 1928. $9 \mathrm{pp} ., 6 \mathrm{flgs}$. Dietributed only upon authorization of Keystone Aircraft Corporation.

210. Ventilation Tests - Entrance Loss to Branches. Jan 1929. 13 pp., 5 flgs.

211. L.M.A.L. Flying Boat Hull - Model Experiments. Dec 1928. 10 pp., 6 figs.

212. Twir Float Seaplane - Effect of Varying the Float Spacing. Jan 1929. 14 pp., 9 figs.

213. Design No. 67 Hull - Modified Lines, Model Experiments. Jan 1929. 11 pp., $6 \mathrm{flgs.}$

214. Rudder Tests with 10,000-Ton Cruiser Model. Feb 1929. 10 pp., 6 flgs.

215. PB-1 Flying Boat Hull - Experiments with a Model of - Bureau of Aeronautics Project 1839. Feb 1929. 10 pp., 6 figs. Distributed only upon authorization of Bureau of Aerongutics.

216. Experiments with Model of V.E. Clark Flying Boat Hull. Mar 1929. 7 pp., 2 flgs. Distributed only upon authorization of V.E. Clark.

217. S1korsky Flying Boat Hulls - Model Experiments. Mar 1929. 12 pp., 8

flgs. Distributed only upon authorization of sikorsky Aviation Corporation.

218. Keystone Aircraft Corporation - Giant Amphibian - Model Test. Apr 1929. $18 \mathrm{pp} ., 10$ figs. Distributed only upon authorization of Eeystone Alrcraft Corporation.

219. Test of Steam and Water and Hot and Cold Water Mixing Valve. Apr 1929. $3 \mathrm{pp}$.

220. 02U Airplane Floats, Mk. I \& Mk. II - Model Experiments. May.1929. 11 pp., 7 flgs.

221. Lockheed Amphiblan and Flying Boat Hulls, Experiments with a Model of. May 1929. 10 pp., 5 flgs. Distributed only upon authorlzation of Lockheed Aircraft Corporation. 


\section{REGULAR SERIES}

222. 02U Airplane Float, Mk. I, Deep Vee Bottom, Experiments with Modified Model. May 1929. 7 pp., 4 figs.

223. Bu. Aero. Design \#71 - 2nd Alternative Lines - Model Experiments. May 1929. 13 pp., 7 figs.

224. Edo Airplane Floats - Model Experiments. Jun 1929. 6 pp., 1 fig. Distributed only upon authorization of Edo Aircraft Corporation.

225. Canceled.

226. Canceled.

227. Data from Experimental Model Basin on Frictional Resistance of Ship Models. Aug 1929. 23 pp., 3 figs.

228. Great Lakes Aircraft Corporation - Twin Floats. Jul 1929. 10 pp., 5 flgs. Distributed only upon authorization of Great Lakes Aircraft Corporation.

229. Ireland Aircraft, Inc., Flying Boat Hull - Experiments with a Model of. Jul 1929. 9 pp., 5 figs. Distributed only upon authorization of Ireland Aircraft, Inc.

230. The Douglas Co.'s Amphibian "Sinbad," Experiments with a Model of. Jul 1929. 10 pp., 5 figs. Distributed only upon authorization of Douglas A1rcraft Corporation.

231. V.E. Clark - Model of Plying Boat Hull - Basin Tests. Jul 1929.10 pp., 5 flgs. Distributed only upon authorization of v.E. Clark.

232. Great Lakes Aircraft Corporation Model Amphibian Hull. Aug 1929. 9 pp., 5 figs. Distributed only upon authorization of Great Lakes Alrcraft Corporation.

233. Design No. 67 Hull - Additional Model Tests. Aug 1929. 13 pp., 7 figs.

234. Bureau of Aeronautics Design No. 80 Hull - Experiments with Model of. Aug 1929. 10 pp., 6 figs.

235. Model Experiments - Design No. 71 Hull Lines Modifled - Project No. 1990. Sep 1929. 8 pp., 4 figs. Distributed only upon authorization of Bureau of Aeronautics.

236. Model Experiments with XP2N-1 Airplane Hull - Bu. Aeronautics Project No. 1982. Sep 1929. 10 pp., 6 flgs. Distributed only upon authorization of Bureau of Aeronautics.

237. XP2M-1 Hull Lines - Model Experiments (Bu. Aero. Project No. 1980). Oct 1929. 13 pp., 8 figs. Distributed only upon althorization of Bureau of Aeronautica.

238. Monocoque Type Floats - Experiments with Models of (Bu. Aeronautics Project No. 1931). Oct 1929. 14 pp., 9 flgs. Distributed oniy upon authorization of Bureau of Aercenautica.

239. Keystone Aircraft Corporation Models K-81 and K-84 - Experiments with. Nov 1929. 8 pp., 4 figs. Distributed only upon authorization of Keystone Alrcraft Corporation.

240. Bu. Aeronautics Design No. 71, Mk III \& Mk IV Hulls (Project No. 2007) Experiments with Models of. Nov 1929. 15 pp., $10 \mathrm{figs}$. Distributed only upon authorization of Bureau of Aeronautics. 


\section{REGULAR SERIES}

241. Sikorsky Aviation Corporation Models S-38-C and S-40 - Experiments with. Nov 1929. 10 pp., 5 figs. Distributed only upon authorization of sikorsky Aviation Corporation.

242. Michael Gregor Amphibian - Experiments with Model of. Nov 1929. 9 pp., $4 \mathrm{figs}$. Distributed only upon authorization of Michael Gregor.

243. Bellanca A1rcraft Corporation Model A1rplane Float - Experiments with. Dec 1929. $10 \mathrm{pp}$., $6 \mathrm{flgs}$. Distributed only upon authorization of Bellanca Alrcraft Corporation.

244. PB-1 and PN-11 A1rplane Hulls - Model Tests to Determine Lateral Stabil1ty (Bureau of Aeronautics' Project \#2008). Dec 1929. 5 pp., 3 figs. Distributed only upon authorization of Bureau of Aeronautics.

245. Bu. Aeronautics Jesign No. 91 Hull - Experiments with a Model of. Jan 1930. $10 \mathrm{pp}$., 6 figs.

246. Sikorsky Aviation Corporation Model S-39 - Basin Experiments. Jan 1930. 9 pp., 5 flgs. Distributed only upon authorization of Sikorsky Aviation Corporation.

247. O2U Airplane - Mark IV Float - Experiments with Model. Jan 1930. 10 pp., 6 figs.

248. Bu. of Aeronautics Design No. 87 Hull and Loening Proposed Alternat1ve Hull - Model Basin Experiments. Mar 1930. 15 pp., 9 flgs.

249. Sikorsky Aviation Corporation - Model S-39, X-411 - Basin Experiments. Mar 1930. 8 pp., 4 figs. Distributed only upon authorization of Sikorsky Aviation Corporation.

250. Test of Model Torpedo (to Determine the Cause of Torpedo Hitting Shutter or Entrance Plates in Hull of Submarine). Mar 1930. $24 \mathrm{pp} ., 17 \mathrm{flgs}$.

251. Brewster \& Company Floats, Series No. 3 (Bu. of Aer. Project \#2112) Model Basin Experiments. Apr 1930. 71 pp., $7 \mathrm{flgs}$. Distributed only upon authorization of Brewster and Company.

252. Experimental Investigation of High Speed Towing Target Design. Apr 1930. $24 \mathrm{pp} ., 11 \mathrm{figs}$.

253. Sikorsky Aviation Corporation - Design S-40 Hull - Model No. X804W. Apr 1930. $8 \mathrm{pp} ., 4 \mathrm{f} i \mathrm{gs}$. Distributed only upon anthorization of sikorsky Aviation Corporation.

254. O2U Airplane Float, Mark V Iines - Experiments with a Model of. May 1930. 11 pp., 6 figs.

255. X02I-1 Amphibian HuII (Bu. Aeronautics Project No. 2142) - Experiments with a Model of. May $1930.10 \mathrm{pp} ., 6$ figs. Distributed only upon authorization of Bureau of Aeronautics.

256. Effects of Shaft Struts versus Spectacle Frames on Propulsion. May 1930. $15 \mathrm{pp} ., 8 \mathrm{figs}$.

257. OlConnor Transatlantic Airways, Inc., 192 Broadway, New York - Model Test on Hull and Side Floats. May 1930. 14 pp., 6 figs. Distributed only upon authorization of 0 'Connor Transatlantic Airways, Inc. 
258. Design No. 87, Class VS A1rplane - Experiments with Model of Mark I HuII - Bureau of Aeronautics Project No. 2152. May 1930. 11 pp., 6

figs. Distributed only upon authorization of Bureau of Aeronaut1cs.

259. Memorandum on Towing Carriage Acceleration. Jun 1930. 13 pp., 1 f \pm g.

260. Elast1c Character1st1cs of Fleet Oilers, by Lt. W.P. Roop, USN. Jun 1930. $41 \mathrm{pp} ., 17 \mathrm{flgs}$.

261. Full Scale Tests of lurret Foundations. Jun 1930. 15 pp., 4 figs.

262. The Strength of Thin Reinforced Tubes under External Pressure - Report of Work Completed and E'rogress of Experiments, by D.F. Windenburg. Jun 1930. $44 \mathrm{pp}$., 15 flgs.

263. Natural Frequencies of Hull Vibration. Jul 1930. 22 pp., 2 flgs.

264. The Effect of Wind on Ship Trials, by Capt. E.F. Eggert, USN. Aug 1930. 13 pp., 2 figs.

265. Preliminary l'ests of Thrust Meter Elements, by D.F. Windenburg. Aug 1930. 18 pp., $10 \mathrm{flgs}$.

266. Brewster and Company Float B-587 - Bureau of Aeronautics Project No. 2197 - Model Basin Tests on. Sep 1930. 9 pp., 5 flgs. Distributed only upon authorization of Brewster and Company.

267. The Influence of Temperature on the Frictional Resistance Experienced by Plane Surfaces Moving in a Fluid, by K.E. Schoenherr. Oct 1930. 34 pp., 8 flgs.

268. Resistance of Var1ous Rudders on a Model of the U.S.S. PATOKA, by Capt. E.F. Eggert, USN. Oct 1930. 3 pp.

269. Design of Electromagnetic Damping Apparatus, by D.F. Windenburg. Nov 1930. 72 pp., 17 f1gs.

270. Report of Rolling Experiments w1th Model No. 2697 Reuresenting U.S. Light Cruisers Nos. 26-31. Nov 1930. 4 pp., 2 figs.

271. A Theoret1cal Investigation of the Point Source-SInk Envelope in Three Dimensions, by D.F. Windenburg. Nov 1930. 22 pp., 4 figs.

272. An Improved Portable Strain Gage, by G.A. DeShazer. Jan 1931. 49 pp., 19 figs.

273. Test of Model Representing Tentative Battleship for 1931. Nov 1930. 16 pp., 10 figs.

274. U.S. Coast Guard - Proposed Fly1ng Boat - Experiments with Model of the Hull. Dec 1930. 12 pp., 6 flgs.

275. See Translation 3 .

276. Test of Drawing Room Model of 10,000 Ton Ifght Cruisers ( $\# 24-\$ 25)$ in Water to Determine Forces Due to Wind. Dec 1930. 20 pp., 12 flgs. 


\section{REGULAR SERIES}

277. Further Comments on Cavitation with 35 Knot Destroyers. Jan 1931. 6 pp., 2 flgs.

278. Instructions for Setting Up and operating Electrically Recording Extensometers Fitted with Bellevue Gages - Serlal Nos. 1 to 5 Inclusive, Model 1930. Jan 1931. 27 pp., 11 f1gs.

279. U.S. Coast Guard Proposed Fly1ng Boat - Experiments w1th Model of Mod1fled Hull. Jan 1931. 13 pp., 7 figs. Distributed only upon authorization of U.S. Coast Guard.

280. Model Experiments on C1rcular Flat D1aphragm Bulkheads for Submarines. Feb 1931. 53 pp., 25 flgs.

281. Experiments with Model of Bureau of Aeronautics' Design No. 103 - Class VO Airplane Float - Project No. 2287. Feb 1931. 10 pp., 7 flgs. D1stributed only upon authorization of Bureau of Aeronautics.

282. A Recording Anemometer for Use in Conducting Sh1p Speed Trials, by G.A. Deshazer. Feb 1931. 19 pp., 6 flgs.

283. Tests of E1ght-Oared Shells. Feb 1931. 5 pp., 2 flgs.

284. Brewster and Company Float B-596 - Bureau of Aeronaut1cs Project No. 2319 - Model Basin Tests on. Feb 1931. 10 pp., 5 figs. Distributed only upon author1zation of Brewster and Company.

285. Tests of Hand Strain Gages, by Charles Tr1lling. Feb 1931. 26 pp., 4 figs.

286. Report - The Small Model Basin - Some of Its Uses and IImitations In Ship Model Research. Dec 1930. 24 pp., 7 flgs.

287. Report of a Study of the Apparent Loss of Metacentr1c lie1ght of a Destroyer When Underway. Mar 1931. $24 \mathrm{pp} ., 11 \mathrm{flgs.}$

288. Invest1gat1on of the Best Method of Towing a Submarine Rescue Chamber (Diving Bell). Mar 1931. 30 pp., 13 flgs.

289. Elementary Theory of Screw Propulsion. Mar 1931. No complate report avallabla.

290. The Manufacture of Model Propellers at the U.S. Experimental Model

Basin. Washington, by R.E. Frisby. Mar 1932. 15 pp., 10 flgs.

291. Iines of stress. Apr 1931. 11 pp., 9 flgs.

292. The E.M.B. Strain Gage, by R.C. Darnell. Apr 1931. 12 pp., 7 flgs.

293. On the Analysis of Ship Trial Data, by K.E. Schoenherr. Apr 1931. 22. pp., 4 figs.

294. See Translation 4.

295. Report of a Study with Models of the Rolling of Cruisers. May 1931. 17 pp., 5 flgs.

296. Wave Destruction at a Reflecting Wall, by J.G. Thews. May 1931. 27 pp., 19 figs. 
297. Bending Loads on CUYAMA at Sea, by Lt. W..P. Roop, USN. May 1931.30 pp., 15 figs.

298. Elastic Tests of Sh1p Models - Longitudinal Bending Load. May 1931. 49 pp., 17 figs.

299. Laminar and Turbulent Flow about Sh1p Models. May 1931. 23 pp., 3 figs.

300. Design No. $106 \mathrm{Hull}$ and Wing Tip Floats - Bureau of Aeronautics Project No. 2353 - Experiments with a Model of. Jun 1931.11 pp., 6 figs.

Distributed only upon authorization of Bur eau of Aeronautics.

301. A Discussion of Synchronism of Ships with Waves. Jun 1931. $10 \mathrm{pp} ., 2$ f1gs.

302. Design No. 71 - Hull and Side Floats - Additional Model Tests - Overload. Jun 1931. 11 pp., 6 figs.

303. Rolling in Waves - Effect of Variations of Form on Roll. Jun 1931. 9 pp., 4 figs.

304. Velocity of Water Currents in U.S. Experimental Model Dasin. Jun 1931. $16 \mathrm{pp} ., 13 \mathrm{figs}$.

305. Vibration Test of Shaft Bossing of U.S.S. HAMIITON at Norfolk Navy Yard, June 11,1931 , by R.T. McGoldrick. Jul 1931. 13 pp., 5 figs.

306. Design No. $106 \mathrm{Hull}$ and Wing Tip Floats - Bureau of Aeronautics Project No. 2353 - Additional Tests with Model of. Jul 1931. 9 pp., 6 figs. Dietributed only upon authorization of Bureau of Aeronautics.

307. Effect of Entrained Water on the Mass Moment of Inertia of Ship Propellers, by R.T. McGoldrick. Jul 1931. 24 pp., 7 figs.

308. Design No. 106 Hull and Wing Tip Floats - Bureau of Aeronautics Project No. 2353 - Additional Tests with Model of. Jul 1931. 10 pp., 6 figs. Distributed only upon authorization of Bureau of Aeronautics.

309. Ses Tranclation 5.

310. Proposed Loening VS Hull - Bureau of Aeronautics Project No. 2360 - Experiments with a Model of. Sep 1931. 10 pp., 6 figs. Distributed only upon authorization of Loening Aeronautical Engineering Corporation.

311. XP2M-1 Hull Iines - Model Experiments with Extended Step - Bureau of Aeronautics Project No. 2421 . Oct 1931. 9 pp., 5 figs. Distributed only upon authorlzati on of Bureau of Aeronautics.

312. Test of Drawing Room Model of U.S. Destroyer HAMILTON in Water to Determine Forces Due to Wind. Oct 1931. 20 pp., 13 figs.

313. Design No. 106 - Hull and Wing Floats - Additional Tests with Modified Model - Bureau of Aeronautics Project No. 2415. Nov 1931. 8 pp., 5 flgs. Distributed only upon authorization of Bureau of Aeronautics.

314. XSG-1 Hull and Wing Tip Floats - Bureau of Aeronautics Project No. 2413 Model Basin Tests. Nov 1931. 10 pp., 6 figs. Distributed only upon authoriza.

tion of Bureau of Aeroneutics. 


\section{REGULAR SERIES}

315. Strength Tests of Submarine Rescue Chamber, by F.G. Ebel. Dec 1931. 28 pp., 11 figs.

316. Report of Observations of Roll - U.S.S. PENSACOLA. Dec 1931. 4 pp., 2 rigs.

317. Reduction of Standardization Trial Data, S.S. CLAIRTON, by Capt. E.F. Eggert, USN. Feb 1932. 12 pp., 8 flgs.

318. Tests to Determine Modulus of Elastic1ty of Steel Specimens from U.S.S. PRESTON. Sep 1931. 13 pp., 10 figs.

319. Wood Models vs. Parafin Models. Feb 1932. 7 pp.

320. Design No. $108 \mathrm{Hull}$ and Outrigger Floats - Project No. 2451 - Experiments with a Model of. Jan 1932. 11 pp., 7 flgs. Distributed only upon authorization of Bureau of Aeronautics.

321. XP2Y-1 Hull and Outrigger Floats - Bureau of Aeronautics Project No. 2462 - Experiments with a Model of. Feb 1932. 11 pp., 6 figs. Distributed only upon authorization of Bureau of Aeronautics.

322. Brewster and Company Float - Model B-708 (Model No. 3, Series 7) - Bureau of Aeronautics Project No. 2387 - Model Basin Experiments. Mar 1932. $10 \mathrm{pp} ., 5 \mathrm{figs}$. Distributed only upon authorization of Brewster and Company.

323. Bullding Wood Towing Models at the U.S. Experinental Model Bas1n, Washington. Mar 1932. 13 pp., 4 flgs.

324. XP2Y-1 Hull and Outrigger Floats - Adiltional Tests - Hull modified to Improve Spray Characterist1cs. Apr 1932. 10 pp., 5 flgs.

325. Model Basin Tests - XSS-2 Hull - Bureau of Aeronautics Project No. 2493. Apr 1932. 11 pp., 6 figs. Distributed only upon authorization of Bureau of Aeronautics.

326. Bureau of Aeronautics Design 91 Hull - Additional Model Basin Tests Model 2995, Bureau of Aeronaut1cs Project 2060. May 1932. 12 pp., $7 \mathrm{flgs}$. Distributed only upon authorlzation of Bureau of Aeronautice.

327. Edo Proposed 02U Type Float - Experiments w1th a Model of (Bureau of Aeronautics Project No. 2390). May 1932. 12 pp., 6 f1gs. Dietributed only upon authorization of Edo Alrcraft Corporation.

328. Causes of Var1at1ons during the Run In Res1stance Measurements on Fowed Sh1p Models. May 1932. No complete report available.

329. Draft of Proposed A.S.M.E. Boller Construction Code - Rules for Construction of Unflred Pressure Vessels Subjected to External Pressure. Jul 1932. $40 \mathrm{pp} ., 4$ s1gs.

330. Bureau of Aeronaut1es Des1gn No. 71 - MK VI and MK VII HuIls - Exper1ments witi Models of. JuI 1932. $13 \mathrm{pp} ., 8 \mathrm{f1gs.}$

331. Model Experiments to Determine the Relative Effect of Propeller Struts and Bossings on the Steering of a Twin Screw Silp. Jul 1932. 8 pp., 9 flgs.

332. Bossing for New Destroyers. Unpublished; see Report 397. 


\section{REGULAR SERIES}

333. Resistance Tests on a 2-Foot Model Submitted by Prof. K. Davidson, by J.G. Thews. Jul 1932. 6 pp., 2 figs.

334. Test of Drawing Room Model of S.S. CLAIRTON Inverted in Water to Determine Forces Due to Wind. Aug 1932. 7 pp., 5 figs.

335. Bureau of Aeronautics Design No. 71 Hulls - Mark VIII to Mark XI Inclusive - Experiments with Models of (Bureau of Aeronautics Project No. 2489). Sep 1932. 22 pp., 17 figs. Distributed only upon authorization of Bureau of Aeronautics.

336. Model Experiments to Determine the Angle of Heel When Turning and the Radius of the Turning Circle for U.S. Destroyer "FARRAGUT." Oct 1932. $15 \mathrm{pp} ., 12 \mathrm{figs}$.

337. Design No. 121, Mark I - Hull and Outrlgger - Experiments with a Model of - Bureau of Aeronautics Project No. 2574. Oct 1932. 11 pp., 7 figs. D1stributed only upori authorization of Bureau of Aeronautics.

338. Brewster and Company Amphibian Float Model - Bureau of Aeronautics Project No. 2424 - Model Basin Tests on. Oct 1932. 8 pp., 5 figs. Distributed only upon authorization of Brewster and Company.

339. Test of Transom Sterns on Destroyers. Nov 1932. $20 \mathrm{pp} ., 17 \mathrm{figs}$.

340. Tests on Resistance and Electro-Magnetic Types of Distant-Reading Apparatus, by G.A. DeShazer. Nov 1932. $19 \mathrm{pp} ., 14 \mathrm{figs}$.

341. Hydrodynamic Characteristics of Twelve Symmetrical Hydrofoils, by R.C. Darnell. Nov 1932. 46 pp., 30 figs.

342. Design No. 121 - Mark II Hull, Mark I Outriggers - Experiments with a Model of - Bureau of Aeronautics Project No. 2591. Dec 1932. 12 pp., $8 \mathrm{figs}$. Distributed only upon authorlzation of Burealu of Aeronautics.

343. Sikorsky Aviation Corporation Model S-42 Hull - Basin Tests on. Dec 1932. 8 pp., 5 figs. Distributed only upon authorlzation of Sikorsky Aviation Corp.

344. Report and Analysis of Standardization Trials - S.S. BIACK FALCON, 3 September 1932. Dec 1932. $23 \mathrm{pp} ., 10 \mathrm{fjgs}$. D1stributed only upon authorization of Black Diamond Steamship Corporation.

345. Test of Model of U.S.S. SALINAS Inverted In Water to Determine Forces Due to Wind. Jan 1933. $10 \mathrm{pp} ., 7 \mathrm{r} 1 \mathrm{gs}$.

346. Design No. 121 - Mark III Hull and Outriggers - Experiments with a Model of - Bureau of Aeronautics Project No. 2607. Jan 1933. 11 pp., 6 figs. Distributed only upon authorization of Burean of Aeronaut1cs.

347. 02U-1, Mark VI Single Float - Bureau of Aeronautics Project No. 2674 Experiments with a Model of. Feb 1933. 10 pp., 6 flgs. Distributed only upon authorization of Bursau of Aeronauties.

348. An Investigation of Some of the Factors Affecting the Rolling of Ships, by M.E. Serat and J.G. Thews. Feb 1933. $40 \mathrm{pp}, 30 \mathrm{figs.}$ 


\section{REGULAR SERIES}

349. Charles M. Stieff Amphibian Float - Experiments with a Model of - Bureau of Aeronautics Project No. 2612. Feb 1933. 11 pp., 7 flgs. D1stributed only upon authorization of Charles M. Stieff, Inc.

350. Comparative Effects of Rudder Types on Propulsion and Steering As Determined by Trials on U.S.S. SALINAS Class. Mar 1933. 270 pp., $14 \mathrm{figs.}$

351. Design No. 121 - Mark IV Hull and Outriggers - Experiments with a Model of - Bureau of Aeronautics Project No. 2631. Mar 1933. 12 pp., 8

figs. Distributed only upon authorization of Bureau of Aeronautics.

352. Design No. 71 - Mark VIII, Modification I - Mark VII Outriggers - Experiments with a Model of - Bureau of Aeronautics Project No. 2634. Mar 1933. 10 pp., 6 flgs. Distributed only upon authorization of Burøau of Aeronaut1cs.

353. O2U Float - Mark VI, Modification I - Bureau of Aeronautics Project No. 2647 - Experiments with a Model of. Apr 1933. 9 pp., 7 figs. Distributed only upon authorization of Bureau of Aeronautics.

354. Construction and Tests of a 40-Foot Catamaran Friction Plane, by W.H. Hoppmann, Jr. May 1933. 17 pp., 7 figs.

355. Design No. 121 - Mark IV HulI and Outr1ggers - Experiments with a Model of - Bureau of Aeronautics Project No. 2631. May 1933. 9 pp., 5 figs. D1stributed only upon authorization of Burseu of Aeronautics.

356. Proposed Rules for Construction of Unfired Vessels Subjected to External Pressure, by D.F. Windenburg. May 1933. 12 pp., 9 figs.

357. Charles M. Stieff Amphibian Float - No. 2 Design - Experiments with a Model of - Bureau of Aeronautics Project No. 2674. May 1933. 10 pp., 6 figs. Distributed only upon authorization of Charles M. Stieff, Inc.

358. Brewster and Company P2D Twin Floats - Experiments with a Model of - Bureau of Aeronautics Project No. 2477. Jun 1933. 10 pp., 7 figs.

Distributed only upon authorization of Brewster and Company.

359. X03C-1 A1rplane Float - Experiments w1th a Model of - Bureau of Aeronautics Project No. 2691. Jun 1933. 11 pp., 7 flgs. Distributed only upon authorization of Bureau of Asronaut1cs.

360. An Investigation of Frictional Values for Iine and Propeller Shaft Bearings and Stuffing Boxes on Ships, by G.A. DeShazer. Jul 1933. 55 pp., 47 f'lgs.

361. X05U-1 Airplane Float - Experiments with a Model of - Bureau of Aeronautics Project No. 2695. Jul 1933. 10 pp., 7 flgs. D1stributed only upon authorization of Bureau of Aeronautics.

362. Test of Model of S.S. SANTA ROSA to Determine Forces Due to Wind. Aug 1933. -9 pp., 8 flgs. Distributed only upon authorization of Federal Shipbuilding and and Dry Dock Company.

363. Analysis of the Standardization Trial Data of the S.S. SANTA ROSA. JuI 1933. 17 pp., 9 figs. D1atributed only upon authorlzation of Federal shipbuilding and Dry Dock Company. 


\section{REGULAR SERIES}

364. X05U-1 Airplane Float - Experiments with a Model of - Bureau of Aeronautics Project No. 2717. Aug 1933. 10 pp., 7 flgs. Distributed only upon authorization of Bureau of Aeronautics.

365. Brewster ana Company Floats, Series No. 6 - Bureau of Aeronautics Project No. 2380 - Experiments with Models of. Aug 1.933. 21 pp., 18 figs. Distributed only upon authorization of Brewster and Company.

366. See Translation 6 .

367. Experiments with a Model of X02D-1 Airplane Float - Bureau of Aeronautics Project No. 2718. Aug 1933. 11 pp., 7 figs. Distributed only upon authorization of Bureau of Aeronautics.

368. Experiments with a Model of Bureau of Aeronautics Design No. 121 - Mark $\nabla$ Hull and Outrigger Floats - Bureau of Aeronautics Project No. 2676. Sep 1933. 10 pp., 7 flgs. Distributed only upon authorization of Bureau of Aeronautics.

369. Experiments with a Model of Mark VII Airplane Float - Bureau of Aeronautics Project No. 2741. Oct 1933. 10 pp., 7 figs. Distributed only upon authorization of Bureau of Aeronautics.

370. Calibration of Thrustmeters Installed on the U.S.S. HAMILTON. Oct 1933. $31 \mathrm{pp} ., 16 \mathrm{flgs}$.

371. B1lge Keel Cavitation, by J.G. Thews. Sep 1933. 8 pp., 8 flgs.

372. Vibration Tests on U.S.S. HAMILTON, by R.T. McGoldrick. Dec 1933. 15 pp., $11 \mathrm{flgs.}$

373. Experiments with a Model of Bureau of Aeronautics Design No. 121 - Mark VI Hull and Outriggers - Project No. 2765. Jan 1934. $11 \mathrm{pp} ., 7 \mathrm{flgs}$. Distributed only upon authorlzation of Bureau of Aeronautics.

374. Rolling Qualities of the Proposed 1935 Battleship Hull, by J.G. Thews and L. Landweber. Jan 1934. $8 \mathrm{pp}$., 9 flgs.

375. Propeller Blade Interference Test, by R.E. Fr1sby. Jan 1934. 27 pp., 19 figs.

376. XP3D-1 A1rplane Hull - Bureau of Aeronautics Projeat No. 2776 - Exper1ments with a Model of. Jan 1934. 11 pp., 7 figs. Distributed only upon authorization of Bureau of Aeronautics.

377. XP3D-1 Airplane Hull - Addit1onal Experiments with Step Modifled. Jan 1934. 10 pp., 7 flgs. Distributed only upon authorization of Buresu of Aeronautics.

378. Experiments with a Model of Class WN Seaplane Float - Bureau of Aeronautics Project No. 2771. Feb 1934. 10 pp., 7 figs. D1stributed only upon authorfzation of Buresu of Aeronatios.

379. Experiments with a Model of Mark VIII Airplane Float - Bureau of Aeronautics Project No. 2775. Apr 1934. 11 pp., 6 figs. Distributed only upon authorization of Bureau of Aeronautics. 
380. Experiments with a Model Having a Long1tudinal Step (Rasin Des1gn). May 1934. 13 pp., 7 f1gs.

381. XP3D-1 Airplane Hull - Additional Experiments with Rear Step Hinged Bureau of Aeronautics Project No. 2836. Jun 1934. 17 pp., $10 \mathrm{flgs.}$ Distributed only upon authorization of Bureau of Aeronautics.

382. Sec Tranclation 7 and Supplement.

383. Experiments with a Model of Edo Aircraft Corporation Float JD - Bureau of Aeronaut1cs Project No. 2849. JuI 1934. 13 pp., 9 figs. Distributed only upon authorization of Edo A1rcraft Corporation.

384. Comparat1ve Tests of Condenser Scoops for Destroyers 364-379 from Tests on Model No. 32, J. Jul 1934. 9 pp., 9 flgs.

385. Collapse by Instab1l1ty of Thin Cylindrical Shells under External Pres. sure, by D.F. Windenburg and Charles Trililing. Jul 1934. 7 pp., 2 ก1gs.

386. Experiments with a Model of Bureau of Aeronautics Mark IX Float - Bureau of Aeronautics Project No. 2875. Aug 1934. 10 pp., 7 figs. Distributed only upon authorization of Bureau of Aeronautics.

387. Theoretical and Emplrical Equat1ons Represented in Proposed Rules for the Construction of Unfired Pressure Vessels Subjected to External Pressure, by D.F. Windenburg. Sep 1934. 11 pp.

388. Experiments with a Model of Bureau of Aeronaut1es Design No. 121 - Mark VII Hull and Outriggers - Project No. 2870 . Oct 1934. 13 pp., $8 \mathrm{flgs.}$ Distributed only upon authorization of Bureau of Aeroneutica.

389. Experiments with Model No. 3333 - Fleetwings Inc. Amph1b1an. Oct 1934. $10 \mathrm{pp} ., 6 \mathrm{flgs}$. Distributed only upon authorization of Fleetwings Inc.

390. Propulsion Problems of a Destroyer, by Lt. Comar. A.S. P1tre, USN. Oct 1934. 200 pp., 99 rigs.

391. RD-2 Amphibian Hull - Experiments w1th a Model of. Nov 1934. 12 pp., 8 $118 \mathrm{~s}$.

392. Preliminary Report on Residuary or Form Res1stance of Sh1ps. Nov 1934. 7 pp., 2 figs.

393. Experiments with a Model of Design No. 135 - Class VN A1rplane Float Bureau of Aeronautics Project No. 2891. Jan 1935. $10 \mathrm{pp}, 7 \mathrm{flgs}$. Distributed only upon authorization of Bureau of Aeronautics.

394. Bureau of Aeronautics Mark X Float - 02U Series - Experiments with a Model of - Project No. 2917. Jan 1935. 13 pp., 5 f1gs. Distributed only upon authorization of Bureau of Aeronautics.

395. A Study of Sh1p Hull V1bration, by R.T. McGoldr1ck. Feb 1935. 32 pp., 13 flgs. 
396. The Influence of Stiffening Rings on the Strength of Thin Cylindrical Shells under External Pressure, by Charles Trilling. Feb 1935. 22 pp., 9 figs.

397. U.S.S. FARRAGUT - Comparative Rudder Tests - Model and Full-Scale, by Lt. Comdr. A.S. Pitre, USN, and J.G. Thews. Mar 1935. 111 pp., 130 figs.

398. Fouling of Ships ' Bottoms - Effect of Physical Character of Surface, by Lt. Comdr. A.S. Pitre, USN, and J.G. Thews. Apr 1935. 19 pp., 30 figs.

399. Seaplane Floats - Early Types - Experiments with Models of - Bureau of Aeronautics Project No. 2952. Apr 1935. 12 pp., 7 figs. Distributed only upon authorization of Bureau of Aeronautics.

400. Models of Seaplane Floats - Early Types - Additional Experiments - Bureau of Aeronautics Project No. 2952. May 1935. 7 pp., 3 figs. Distributed only upon authorization of Bureau of Aeronautics.

401. Experiments with Grumman Alrcraft Engineering Corporation Models JF-1 and JF-1 Modifled - Bureau of Aeronautics Project 2965. May 1935.13 pp., 9 figs. Distributed only upon authorization of Grumen Alrcraft Engineering Corporation.

402. See Trenslation 8 .

403. U.S.S. WORDEN - Propulsion and Turning Performance - Model and FullScale, by Lt. Comdr. A.S. Pitre, USN. Aug 1935. 57 pp., 38 figs.

404. Experiments with a Model of Design No. 135, MK I - Class VN Alrplane Float - Bureau of Aeronautics Project No. 2991. Jul 1935. 12 pp., 8 figs. Distributed only upon authorization of Bureau of Aeronautics.

405. Grumman Aircraft Engineering Corporation Model JF-1 - Additional Tests with Modified Stern - Bureau of Aeronautics Project No. 2995. Aug 1935. 9 pp., 6 figs. Distributed only upon authorization of Grumman Alrcraft Engineering Corporation.

406. O2U Float Series - Mark XI Float - Experiments with a Model of - Bureau of Aeronautics Project No. 2996. Sep 1935. 13 pp., 9 flgs. Distributed only upon authorization of Bureau of Aeronautics.

407. Design No. 137, Mark II Hull - Experiments with a Model of - Bureau of Aeronautics Project No. 3025. Oct 1935. 10 pp., 6 figs. Distributed only upon authorization of Bureau of Aeronautics.

408. The Influence of Shallow Water on the Resistance of a Cruiser Model, by J.G. Thews and L. Landweber. Oct $1935.31 \mathrm{pp}, 18 \mathrm{figs.}$

409. Design No. 71, Mark VIII Hull, Mark VII Outriggers - Model Experiments with C.G. Moved Forward - Bu. Aeronautics Project No. 3028. Oct 1935. $10 \mathrm{pp} ., 6$ figs. Distributed only upon authorization of Bursau of Aeronautics. 
410. Design No. 121, Mark VIII Hull - Experiments with a Model of - Also Comparative Test with the Model Representing Design No. 137, Mark I Hull Bureau of Aeronautics Project No. 3007. Nov 1935. 14 pp., 9 figs. Distributed only upon authorization of Burealu of Aeronautics.

411. Design No. 137, Mark III Hull - Experiments with a Model of - Bureau of Aeronautics Project No. 3057 . Nov 1935. 11 pp., 6 figs. Distributed only upon authorization of Bureau of Aerongutics.

412. Design No. 139, Class VSO Airplane Hull - Experiments with a Model of Bureau of Aeronautics Project No. 3037 . Jan 1936. 9 pp., 6 figs. Distributed only upon authorization of Bureau of Aeronautics.

413. 02U Float Series - Mark XI Float with Extended Stern Fin - Experiments with a Model of. Jan 1936. 10 pp., 6 figs.

414. A Thirty-Inch Model of the S.S. CLAIRTON in Shallow Water, by J.G. Thews and L. Landweber. Jan 1936. $14 \mathrm{pp} ., 11 \mathrm{flgs.}$

415. Design No. 140 - Class Vo Seaplane - Experiment's with a Model of Mark XII Float - Bureau of Aeronautics Project No. 3064. Jan 1936. 10 pp., 6 flgs. Distributed only upon authorization of Bursau of Aeronautics.

416. Design No. 137, Mark IV Hull - Experiments with a Model of - Bureau of Aeronaut 1cs Project No. 3077. Feb 1936. 12 pp., 8 figs. Distributed only upon authorization of Bureau of Aeroneutics.

417. Experiments with a Model Submitted by Sundstedt Alrcraft Corporation. Mar 1936. 9 pp., 6 figs. Distributed only upon authorization of Sundstedt A1rcraft corporation.

418. On the Resistance of a Heavy Flexible Cable for Towing a Surface Float behind a Ship, by J.G. Thews and L. Landweber. Mar 1936. 17 pp., 4 figs.

419. Design No. 140 - Class VO Seaplane - Experiments with a Model of Mark XIII Float - Bureau of Aeronautics Project No. 3035. Apr 1936. 13 pp., $8 \mathrm{flgs}$. Distributed only upon authorization of Bureau. of Aeronautics.

420. XPBS-1 Hull, Iines - Experiments with a Model of - Bureau of Aeronautics Project No. 3103. May 1936. 13 pp., 8 flgs. Distributed only upon authorization of Bursau of Aeronautics.

421. Classified.

422. The Tension in a Loop of Cable Towed through a Fluld, by J.G. Thews and L. Landweber. Jun 1936. 6 pp., 5 flgs.

423. Design No. 140 - Class Vo Seaplane - Experiments with a Model of - Bureau of Aeronautics Project No. 3112. Jul 1936. 10 pp., 6 figs.

Distributed only upon authorization of Bureal of Aeronautics.

424. Analysis of Six Zeiss Contax Lenses, by L. Landweber. Aug 1936. 7 pp., 5 figs. 
425. Experiments with a Model Having a Longltudinal Step (Basin Design). Sep 1936. 1? pp., 6 flgs.

426. XPB2Y-1 Alrplane Hull - Experiments with a Model of - Bureau of Aeronaut1cs Project No. 3139. Oct 1936. 11 pp., 7 f1gs. Distributed only upon authorization of Bureal of Aeronautics.

427. XPB2Y-1 Alrplane - Alternat1ve Hull - Experiments with a Model of - Bureau of Aeronautics Project No. 3139. Nov 1936. 10 pp., 6 flgs. D1atributed only upon authurization of Bureau of Aeronautics.

428. Methods of Determining the Thrust Deduction of Inboard Propellers and Outboard Propellers Separately for Twin Skeg, Four Screw Battleship. Model No. 3441. Dec 1936. 4 pp., 5 flgs.

429. Effects of Modiflcations to Bettleship Models on Resistance and Propulsion. Dec 1936. 19 pp., 17 flgs.

430. The Power Cost of Roll Stabilization on the CONTE DI SAVOIA, by J.G. Thews and L. Landweber. Jan 1937. 14 pp., 9 flgs.

431. XPB2Y-1 A1rplane Hull - Experiments with a Model of - Bureau of Aeronautics Project No. 3139. Mar 1937. 13 pp., 7 f1gs. Distributed only upon authorlzation of Bureau of Aeronautics.

432. Bureau of Aeronautics Design No. 142 A1rplane Hull - Experiments with a Model of - Bureau of Aeronautics Project No. 3173. Jun 1937. 9 pp., 6 flgs. D1stributed only upon authorization of Bureau of Aeronautics.

433. A Comparison of Three Methods of Rolling Ship Models, by J.G. Thews and L. Landweber. Jun 1937. 19 pp., 9 flgs.

434. Bureau of Aeronaut1es Design No. 143 - Class VPB A1rplane Hull - ExperIments with a Model of. Jun 1937. 9 pp., 6 flgs. Distributed only upon authorization of Bureau of Aeronautics.

435. Model No. 3324 - Additional Test - Longltudinal steps (Basin Design). Jun 1937. 10 pp., 6 flgs.

436. Curt1ss Design Seaplane Float - Experiments with a Model of. Jun 1937. 5 pp., 2 flgs. Distributed only upon authorization of Curtiss Engineering Corporation.

437. Mark XIV Float - Experiments with a Model of - Bureau of Aeronautics Project No. 3199. Aug 1937. 10 pp., 6 flgs. Distributed only upon authoriza. tion of Bureau of Aeronaut1cs.

438. XoSU-1 A1rplane Float - Polnted Step Type - Experiments with a Model of. Aug 1937. 9 pp., 6 flgs.

439. Model XPB2Y-1 Alrplane Hull - Add1t1onal Tests with Modified Afterbody Bureau of Aeronautics Project No. 3217. Aug 1937. 12 pp., 8 flgs. Distributed only upon authorlzation of Bureau of Aeronautica.

440. The Effect of Jolnt Eccentricity on the Ultimate Strength of Plating in Compression, bj John Vasta. Oct 1937. 5 pp., 3 I1gs.

441. Invest1gation of Elast1c Character1st1cs of Box G1rders, by F.G. Ebel. oct 1937. 13 pp., 9 figs. 
442. The Effect of the Turn of the B1lge on Roll Damping, by J.G. Thews and L. Landweber. Jan 1938. 8 pp., 9 figs.

443. Model XPB2Y-1 Alrplane Hull - Add1t1onal Tests w1th Modifled Afterbody Bureau of Aeronautics Project No. 3139. Feb 1938. 8 pp., $6 \mathrm{flgs.}$ D1stributed only upon authorization of Bureau of Aeronautica.

444. Experiments w1th a Model of Bureau of Aeronautics Mark XV Float - Project No. 3276. Feb 1938. 11 pp., 6 figs. Distributed only upon authorization of Bureau of Aeronaut1cs.

445. The Ultimate and Critical Compressive Strength of Tee Stiffeners, by John Vasta. Feb 1938. 19 pp., 10 flgs.

446. The Effect of Openings on the Ultimate Tensile Strength of Flat Plates. Mar 1938. 12 pp., 5 flgs.

447. Vibration Measurements Taken on Range Finder of U.S.S. VINCENNES, by D.F. WIndenburg and R.T. McGoldrick. Apr 1938. 6 pp., 1 fig.

448. XPB2Y-1 Alrplane Hull - Tests on Or1ginal Lines w1th Modifled Main Step. May 1938. 8 pp., 5 flgs. D1stributed only upon authorization of Bureau of Aeronautics.

449. Experiments with Vibration Neutralizers, by R.T. McGoldrick. May 1938. 24 pp., 15 flgs.

450. Discontinuous Ant1-Rolling Keels, by J.G. Thews. May 1938. 26 pp., 15 figs.

451. Experiments with a Model of XS03C-1 A1rplane Flcat - Bureau of Aeronautics Project 3307 . Jun 1938. 9 pp., $6 \mathrm{flgs}$. Distributed only upon authorization of Bureau of Aeronautics.

452. Compression Tests of Ship-Structure Assemblies, by John Vasta. Jun 1938. 21 pp., 15 r1gs.

453. Form Resistance Experiments of 1937 and 1938, by C.E. Janes. Jul 1940. 37 pp., 65 rigs.

454. XS02U-1 A1rplane Float - Polnted Step Type - Experiments with a Model of - Bu. Aer. Project No. 3315. Jul 1938. 9 pp., 6 flgs. Distributed only upon authorization of Bureau of Aeronautics.

455. Preliminary XPEM- 1 Hull Lines - Experiments with a Model of - Bureau of Aeronautics Project No. 3266. Aug 1938. 10 pp., 6 flgs. Distributed only upon authorization of Bureau of Aeronautics.

456. XPBM-1 Hull Lines - Experiments with a Model of - Bureau of Aeronautics Project No. 3361 . Sep 1938. 11 pp., 6 figs. Distributed only upon authorization of Bureau of Aeronautics.

457. The Elastic Stability of Tee Stiffeners, by D.F. Windenburg. Nov 1938. $16 \mathrm{pp} ., 5$ flgs.

458. Tests of a One-E1ghth Scale Model Turret Foundation for Battleships 55 and 56, by Lt. R.D. Conrad, USN. Dec 1938. 99 pp., 67 flgs. 
459. Turret Displacement Measurements - U.S.S. NASHVILLE, by E.E. Johnson. Apr 1939. 15 pp., 9 figs.

460. Tests of a Model in Restricted Channels, by L. Landweber. May 1939. 30 pp., 19 figs.

461. XPBM-1 Hull Lines - Model Tests with Mod1fied Step - Bureau of Aeronaut$1 \mathrm{cs}$ Project No. 3361 . Jun 1939. $10 \mathrm{pp},, 6 \mathrm{flgs}$. Distributed only upon authorization of Bureau of Aeronautics.

462. Des1gn No. 142, Mark 1 A1rplane Hull - Experiments with a Model of - Bureau of Aeronautics Project No. 3345. Sep 1939. 9 pp., 6 flgs. Distributed only upon authorization of Bureau of Aeronautics.

463. Alr Flow through Small Segments of Armor Gratings with Duct Approaches. Jan 1940. $11 \mathrm{Fp} ., 4 \mathrm{flgs}$.

464. Design No. 180, Class VPB A1rplane Hull - Experiments with a Model of Bureau of Aeronaut1cs Project 3365 . Oct 1939. 9 pp., 6 f1gs. Distributed only upon authorization of Bureau of Aeronautics.

465. Design No. 154 Float - Experiments w1th a Model of - Bureau of Aeronaut$1 \mathrm{cs}$ Project No. 3240. Nov 1939. 9 pp., 6 figs. Distributed only upon authorization of Bureau of Aeronautics.

466. Further Structural Tests of Turret Models, by Lt. J.M. Farrin, USN. Dec 1939. 54 pp., 47 f1gs.

467. Service Strain Tests of Hull Structures - A Review of Work of the ExperImental Model Basin to and Including the Year 1939, by Lt. Comdr. W.P. Roop, USN, Jan 1940. $15 \mathrm{pp}$.

468. Serv1ce Strain Tests - Technique and Procedure. Mar 1940. 27 pp., 18 figs.

469. The Strength of Sh1p Plating under Edge Compression, by J.M. Frankland. May 1940. 28 pp., 13 r1gs.

470. Interaction between Propeller and Hull, by Dr. K.E. Schoenherr and A.Q. Aquino. Mar 1940. $49 \mathrm{pp} ., 16 \mathrm{flgs.}$

471. Strain Tests on Flight-Deck Framing of USS YORKTOWN and USS WASP, by Lt. Comdr. W.P. Roop, USN. Feb 1941. 61 pp., 35 figs.

472. Classifled.

473. Classified.

474. Strain Distribution on Specimens in a Fatigue Test, by Dr. D.F. Windenburg. Mar 1941. 23 pp., 16 figs.

475. Model Series at the U.S. Experimental Model Basin, 1900-1940. by It. J.M. Farrin, USN. Dec 1940. $66 \mathrm{pp} ., 45$ figs. 


\section{REGUIAR SERIES}

476. Tactical Trial Methods and Equipment, by Lt. J.M. Farrin, USN, and I. Landweber. Mar 1941. 37 pp., 27 figs.

477. CLASSIFIED

478. CLASSIFIED

479. Analysis of Shekleton's Report on Underwater Explosions of September 1918, by Comdr. W.P. Roop, USN. Jun 1943. 22 pp., 3 figs.

480. Report on Underwater Explosions, by Prof. E.H. Kennard. Oct 1941. 51 pp., 17 figs.

481. Effects of Impact on Simple Elast1c Structures, by Dr. J.M. Frankland. Apr 1942. 34 pp., 27 figs.

482. Theory of the Hydraulic Brake or Buffer, by Dr. B.I. Miller. Jan 1942. 20 pp., 9 figs.

483. The TMB Linear Sweep Oscillator, by Ens. G. Robert Mezger, USNR. Dec 1941. 9 pp., 4 figs.

484. CLASSIFIED

485. Flow about a Palr of Adjacent, Parallel Cylinders Normal to a Stream Theoretical Analysis, by L. Landweber. Jul 1942. 27 pp., 13 figs.

486. CIASSIFIED

487. Instruments and Methods for Measuring the Flow of Water around Ships and Ship Models, by C.E. Janes. Mar 1948. 29 pp., 26 figs.

488. Impact Measurements on a Free-Edge Plate, by Lt. J.S. Parkinson, USNR. Jan 1942. 18 pp., 26 figs.

489. Effects of Underwater Explosions, General Considerations, by Prof. E.H. Kennard. Sep 1942. 17 pp., 3 figs.

490. Protection against Underwater Explosion - Plastic Deformation of a Circular Plate, by Dr. A.N. Gleyzal. Sep 1942. 17 pp., 7 figs.

491. Model Tests of Composite Structures to Resist Underwater txplosion, by Comdr. J.S. Parkinson, USNR, and Capt. W.P. Roop, USN. Mar 1945. 99 pp., 36 figs.

492. The Design of Ship Structure to Resist Underwater Explosion - Nominal Theory, by Capt. W.P. Roop, USN. Aug 1943. 34 pp., 14 figs.

493. Fatigue Tests of Diesel Engine Piston Rods, with and without Sprayed Metal Coating, by J.V. Coombe. Aug 1942. 23 pp., 21 figs. 
REGULAR SERIES

494. CLASSIFIED

495. Calculated and Observed Speeds of Cavitation about Two- and Three-Dimensional Bodies in Water, by Hugh B. Freeman. Nov 1942. 18 pp., 19 figs.

496. CIASSIFIED

497. Theoretical and Experimental Investigation of the Shaft-Restraining Block, by J.d'H. Hord. Feb 1943. 57 pp., 27 figs.

498. Model Tests of Turrets and Foundations and Their Influence on Full-Scale Design, by R.T. McGoldrick. Nov 1943. 45 pp., 17 figs.

499. CLASSIFIED

500. CLASSIFIED

501. Static Strength Tests of Diesel Engine Crankcases GMC 16-184 and EMC 16-184-A for 110-Foot Patrol Boats, by J.W. Day. Aug 1943. 28 pp., 23 figs. FOR OFFICIAI USE ONLY.

502. An Electronic Voltage Regulator, by It. G. Robert Mezger, USNR. Mar 1943. i1, $19 \mathrm{pp}$., 5 figs.

503. Properties of Medium Steel at High Rates of Loading, by Comdr. W.P. Roop, USN, and Ens. Helen I. Carrigan, USNR. Jun 1943. ix, 40 pp., 18 figs.

504. The Effect of Rigid Guide Vanes on the Vibration and Drag of a Towed Circular Cylinder, by G. Grimminger. Apr 1945. 10 pp., 5 figs.

505. The 12-Inch Variable Pressure Water Tunnel - Propeller-Testing Procedure, by W.H. Bowers. Nov 1943. 27 pp., 12 figs.

506. A Summary of Static Deflection Data on Three Series of Plastic Diaphragms, by F. Mintz. Oct 1943. 23 pp., 18 figs.

507. A Method of Estimating Equivalent Static Loads in Simple Elastic Structures, by Dr. G.E. Hudson. Jun 1943. ix, 18 pp., 15 figs.

508. The Taylor Model Basin Diaphragm Blast Gage, by B. Sussholz. Dec 1943. ix, $28 \mathrm{pp} ., 27$ figs.

509. Early and Ultimate Damage Due to Underwater Explosions against 10-Inch Dlaphragms, by Dr. G.E. Hudson. Aug 1943. vi, 25 pp., 16 figs.

510. The Vertical Motion of a Spherical Bubble and the Pressure Surrounding It, by Prof. G.I. Taylor, F.R.S. Aug 1943. 1x, 28 pp., 4 figs. 
511. Explosive Load on Underwater Structures As Modified by Bulk Cavitation, by Prof. E.H. Kennard. May 1943. i1i, 26 pp., 15 figs.

512. Motions of a Pulsating Gas Globe Under Water - A Photographic Stuãy, by Lt. D.C. Campbell. May 1943. 65 pp., 35 figs.

513. Torque on a Non-Rotating Propeller Moving Axially through Water, by Dr. K.E. Schoenherr, W.H. Bowers, and A.Q. Aquino. Feb 1043. 6 pp., 2 figs.

514. CLASSIFIED

515. CLASSIFIED

516. Analysis of Data on Plastic Deformation of a Clamped Thin Circular Plate under Hydrostatic Pressure, by A.N. Gleyzal, Ph.D. Apr 1047. 23 pp., 14 figs.

517. Radial Motion of Water Surrounding a Sphere of Gas in Relation to Pressure Waves, by Prof. E.H. Kennard. Sep 1043. x, 38 pp., 8 figs.

518. Analysis of Vibration in the Propelling Machinery of the Battleships NORTH CAROLINA and WASHINGTON (BB55 and BB56), by R.T. MCGoidrick and W.F. Curtis. Mar 1945. xx11, 88 pp., 52 figs.

519. CIASSIFIED

520. Small-Scale Underwater Explosions under Reduced Atmospherlc Pressure, by Lt. D.C. Campbell, USNR, and C.W. Wyckoff. Norr 1043. 33 pp., 28 figs.

521. Operational Analysis of Electric Filters Used with Electromechanfcal Transducers, by Lt. D. Bancroft, USNR. Mag 1944. vi, IG pp., $15 \mathrm{flgs.}$

522. CIASSIFIED

523. Instrumentation for Measurement of Underwater Explosion Pressures, by Dr. M.A. Greenfield and Dr.M.M. Shapiro. Sep 1944. v1, 52 pp., 29 figs.

524. Construction and Operation of the Taylor Model Basin 5000-Pound Vibration Generator, by Edgar 0. Berdahl. Apr 1944. 26 pp., 19 flgs.

525. A Microsecond Time-Delay Circuit, by Lt. G. Robert Mezger, USNR. May 1944. 12 pp., 9 figs.

526. An Electronically Regulated D-C Power Supply, by Lt. G. Robert Mezger, USNR. Mar 1044. iv, 9 pp., 8 figs.

527. The Effect of a Pressure Wave on a Plate or Diaphragm, by Prof. E.H. Kennard. Mar 1944. xiv, 93 pp., 32 figs. 


\section{REGULAR SERIES}

528. The Development of Antivibration Devices for the Mark 48 Rangefinder,

by F. Mintz. Mar 1948. 73 pp., 51 figs.

529. Stresses and Deformations in Knees of Frames and in Sharply Curved Beams with Variable Cross Section, by Comdr. H.M. Westergaard, USNR. Jan 1945. iv, $49 \mathrm{pp} ., 11$ figs.

530. Notes on Rudder Action and Steering Characteristics of Ships, by $N$. Minorsky. Jul 1938. xil1, 118 pp., 25 IIgs.

531. CLASSIFIED

532. Plastic Deformation of a Thin Circuler Plate under Pressure, by Dr. A.N. Gleyzal. Mar 1946. 31 pp., 13 figs.

533. The Shape and Tension of a Iight, Flexible Cable in a Uniform Current, by L. Landweber and M.H. Protter. Oct 1044. 33 pp., 10 figs.

534. Introduction to Non-Inear Mechanics. Part I - Topological Methods of Non-Iinear Mechenics, by Dr. N. Minorsky. Dec 1944. x, 133 pp., 64 figs. FOR OFFICIAI USE ONLF.

535. The Delineation of Surface Iines of Flow and Wave Profiles at the David Taylor Model Basin, by Lt. J.F. Hutchinson, USNR. May 1944. 9 p. 7 figs.

536. Analysis of Motions and Stresses in a High-Impact Shock Testing Machine, by Dr. B.L. Miller. Jul 1944. 32 pp., 20 figs.

537. Canceled.

538. The Use of Dry Mortar as a Bearing and Grouting Material at the David Taylor Model Basin, by Comdr. Boyd S. Brooks (CEC), USN. Jan 1048. 62 pp., 45 figs.

539. Construction and Operation of the Losenhausen 440-Pound Vibration Generator, by E.O. Berdahl, C Sp(X) (AA), USNR. Apr 1945. 22 pp., 14 figs.

540. Design and Performance of the TMB Planing Float as a Towed Position Indicator, by I. Landweber and Ens. P. Elsenberg, USNR. Mar 1945. iv, 41 pp., 21 flgs.

541. CLASSIFIED

542. CIASSIFIED

543. CLASSIFIED

544. CLASSIFIED 
545. A Tourmaline-Crystal Hydrophone, by M. Strasberg. Mar 1946. 12 pp., 7 figs.

546. Introduction to Non-Linear Mechanics. Part II - Analytical Methods of Non-Iinear Mechanics, by Dr. N. Minorsky. Sep 1945. v, 111 pp., 16 f1gs FOR OFFICIAL USE ONLY.

547. Axial Vibration of Propulsion Systems of Battleshlps of the BB57 through 60 Class, by R.T. McGoldrick. Jan 1948. $31 \mathrm{pp.,} 18 \mathrm{flgs.}$

548. Natural Frequencles of Side Plating, Bulkheads, Decks, and Radar and Rad10 Supports, Measured Abroad Three Crusiers, Three Destroyers, a Submarine, and a Battleship, by F.F. Vane. Apr 1948. 59 pp., 35 figs.

549. Design, Operation, and Maintenance of a Meter for Recording the Air Content of Water in the David Taylor Model Basin Water Tunneis, by Dr. A. Borden. Dec 1946. 26 pp., 8 figs.

550. Characteristics of the NRL Mark 3 Boat-Type Buoy and Determination of Mooring-Line Sizes, by Ens. P. Eisenberg, USNR. Sep 1945. iv, 75 pp., 48 figs.

551. Ax1al Vibration of Propulsion Systems of Battleships of the BB61 through 66 Class, R.T. McGoldrick. Feb 1948. 37 pp., 32 figs.

552. CIASSIFIED

553. The Dynamical Stab1lity of Torpedoes, by M.A. Garstens, Sc.D. Oct 1946 . 23 pp., 7 figs. Revised Edition by L. Landweber and A.J. Volta Feb 1949. 26 pp., 7 figs.

554. Construction and Operation of the Losenhausen 44,000-Pound Vibration Generator, by E.O. Berdahl. Apr 1947. 30 pp., 17 figs.

555. CLASSIFIED.

556. The Preparation of Letter Correspondence at the David Taylor Model Basin. Dec 1945. Canceled. 
557. Photographs of the Flow about an NACA 23015 Airfoll at an Effective Reynolds Number of 480,000, by Ens. R.R. Staley, USNR. Apr 1946. 22 pp., 15 figs.

558. Introduction to Non-Linear Mechanics. Part III - Non-Linear Resonance, by Dr. N. Minorsky. May 1946. 132 pp., 30 figs. FOR OFFICIAL USE ONLY.

559. An Electrical Engine-Pressure-Indicating Device, by Lieut. Comdr. G. Robert Mezger, USNR. Aug 1947. 29 pp., 12 flgs.

560. Model Tests and Full-Scale Observations of the Launching of the USS SEANGRI-IA (CV38), by J.H. Curry and C.G. Moody. Jun 1948. 5e pp., 34 figs.

561. A Regulated High-Voltage D-C Power Supply, by George W. Cook . Jul 1046. $19 \mathrm{pp} ., 10 \mathrm{flgs}$.

562. Measurements of Strains and Deflections of a 1/8-Scale Mode 1 of the Turret Stool for Cruisers of the CLl44 Class, by E. Wenk, Jr. Sep 1047. 35 pp., 14 figs.

563. Instruments at the David Taylor Model Basin for Measuring Vibration and Shock on Ship Structures and Machinery, by R.B. Allnutt and F. Mintz. $\mathrm{Jul}$ 1948. $100 \mathrm{pp}$, $60 \mathrm{flgs}$.

564. Introduction to Non-Iinear Mechanics. Part IV - Relaxation Oscillations, by Dr. N. Minorsky. Sep 1946. 80 pp., 38 figs. FOR OFFICIAL USE ONLY.

565. A Carrier-Type Strain Indicator, by George W. Cook. Nov 1946. 30 pp., 18 figs.

566. The Interaction between Shock-Mounted Equipment and Its Supporting Structure under a Step-Function Excitation, by S. Fifer and R.D. Specht. Sep 1947. 11 pp., 4 figs.

567. CLASSIFIED

568. A General Methods for the Numerical Calculation of the Roots of a Polynomial Equation, by A.N. Gleyzal and S. Fifer. Mar 1948. 8 pp. 


\section{REGULAR SERIES}

569. A Manual for Visitors to the David W. Taylor Model Basin, by Capt. H.E. Saunders, USN, and M. Hodtwalker. Apr 1947. 112 pp., 57 figs.

570. (NS 724-004e). Wire-Resistance Gages for the Measurement of Large Strains, by Harry Shoub. Mar 1, $50.15 \mathrm{pp} ., 5$ figs.

571. Experimental Analysis of Stress and Deformation of a 1/10-Scale Model 8-Inch Gun Turret for the CAl39 Class Cruisers, by Edward Wenk, Jr. Feb 1948. 58 pp., 32 figs.

572. The Response of a System with a Single Degree of Freedom to a Blast Load, by M. Levenson and B. Sussholz. Dec 1947. 24 pp., 15 figs.

573. Analysis of Test Data on the Performance Characteristics of Planing and Displacement Floats for Supporting Submerged Loads, by P. Elsenberg. Oct 1947. $58 \mathrm{pp}$., 44 figs.

574. A and $B$

Report of an Inspection of Certain European Hydromechanical and Aeromechanical Test and Research Fecilities During October-December 1945. Volume I - General Technical Report. Volume 2 - Description of Test Facllities and Apparatus, by Captain H.E. Saunders, USN. Aug 1949. $491 \mathrm{pp} ., 264$ figs.

575. (NS 713-065). Determination of Critical Pressures for the Inception of Cavitation in Fresh and See Water as Influenced by Air Content of the Water, by S.F. Crump. Oct 1949. 40 pp., 17 figs.

576. The Prediction of the Effective Horsepower of Ships by Methods in Use at the David Taylor Model Basin, by M. Gertler. Sep 1947. 33 pp., 4 figs. 2nd ed. Dec 1947. 33 pp., 5 figs.

577. Tests of TMB Model 3867 Representing the Atlantic Refining Company Tanker Design T2-SE-AI, by A.Q. Aquino. Jul 1947. 14 pp., 10 figs. Distributed only upon authorization of Atlantic Refining Company.

578. Tests of TMB Model 4013 Representing the Sun Shlpbullding and Dry Dock Company Proposed Twin-Screw Passenger and Trallershlp, by A.Q. Aquino. Jul 1947. 15 pp., 9 figs. Distributed only upon authorization of Sun Shipbuilding and Dry Dock Company. Superseded by Report 639 . 
579. Restricted Channel Tests for the Panama Canal. Status of One-Way and

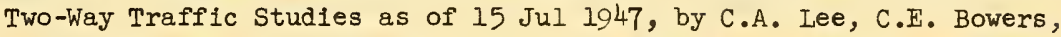
and F.D. Bradley. Jul 1947. 9 pp., 2 figs. Superseded by Report 601.

580. Wake Survey in Way of Propeller Disk on TMB Model 4013 Representing the Sun Shipbullding and Dry Dock Company Proposed Twin-Screw Passenger and Trailership, by W.H. Norley. Jul 1947. 2 pp., $1 \mathrm{flg}$. Distributed only upon authorization of Sun Shipbuilding and Dry Dock Company.

581. Theory of the Belt-Driven Torsiograph, by Alice R. Welch. Jul 1947. $18 \mathrm{pp} ., 8$ figs.

582. Calculation of Fiexural Critical Frequencies of Ship Hulls by Prohl's Method, by E.J. Adams and Alice R. Welch. Jul 1947. 8 pp., 2 figs.

583. Wake Survey of the Mark 13 Torpedo, by H.A Eggers, Jul 1947. 27 pp., 16 figs.

584. Forces Measured in a Towline during Towing Tests of a Series G-40 HighSpeed Sled Target, by G.B. Mayfield. Aug 1947. 6 pp.

585. Tests of TMB Model 4030 Representing the Federal Shipbuilding and Dry Dock Company 600-Foot Single-Screw Tanker, by I. Goldman. Jul 1,47. 29 pp., 17 figs. Distributed only upon authorization of Federal Shipbuilding and Dry Dock Company.

586. Tests of TMB Models 4005, 4005-1, and 4006 Representing Cox and Stevens 160-Foot and 270-Foot Yangtze River Vessels, by M. Gertler. Jul 1947. $29 \mathrm{pp} ., 23 \mathrm{flgs.}$ Distributed only upon authorization of Cox and Stevens, Inc.

587. Tensile-Strength Tests of Experimental Rigging Insulators, by J.G. McGinley. Sep 1947. 12 pp., 3 figs.

588. Preliminary Report of the Tests of Models of Towing Targets, by J.H. Curry and Jack Posner. Aug 1947. 28 pp., 20 flgs. Superseded by Report 595 .

589. Forces Measured in a Towline during Towing Tests of a Series G-60 EighSpeed Sled Target, by J.G. McGinley. Sep 1947. 7 pp. 
590. The Torque Converter Type "Foettinger," by W. Spannhrke. Sep 1947. 7 pp., 3 figs.

591. The Torque Converter to be Employed on Cellulose Hydrolyzers at the Northern Regional Research Institute, Peoria, Iliinois, by $W$. Spannhake. Sep 1947. 5 pp., 2 figs.

592. Research on the Development and Propagation of Hyarodynamic Noise. Progress Report 2 - Progress on the Development of Bot-Wire Methods for Velocity Measurements in Water, by M.S. Macovsky. Oct 1947. 7 pp., 3 figs.

593. Tensile Tests of Fiberglas Micarta Rigging Insulators, by J.G. McGinley. Jul 1947. 7 pp., 3 Iigs.

594. Resistance and Propulsion Tests of a 25-Foot Model and a 20-Foot Model of U.S. Maritime Commission Tanker T2-SE-AI, by H.M. Fitzpatrick. Oct 1947. $15 \mathrm{pp} ., 12 \mathrm{figs}$. Distributed only upon authorization of Atlantic Refining Company.

595. Results of Experiments with Models of High Speed Towing Targets Including Estimates of Full-Scale Target Drag and Cable Tension, by J.H. Curry and Jack Posner. Nov 1947. $41 \mathrm{pp} ., 34 \mathrm{figs.}$

596. Hydrostatic Tests of High-Pressure Steam Valves Removed from Ex-German Destroyers Z-37 and Z-39, by C.I. Pittiglio and J.G. McGinley. Jan 1948. 11 pp., 6 I1gs.

597. A List of Dav1d W. Taylor Model Basin Unclassified Publications. Superseded by Report 1160 .

598. Resistance and Propulsion Tests of Model 3946-2 Representing a 755-Foot Passenger Iiner of U.S. Maritime Commission Design P4-S2-HI, by W.H. Norley. Nov 1947. 13 pp., 5 flgs. Distributed only upon authorization of U.S. Maritime Commission.

599. A Frame for Testing Structural Models, by Edward Wenk, Jr. Mar 1049. 23 pp., 11 figs. 
600. The Graphical Solution of 45-Degree Strain-Rosette Data and Determination of Error in the Calculated Stresses Due to Errors in Measured Strains, by Margaret E. Duke and Edward Wenk, Jr. Nov 1949. 20 pp., 3 figs.

601. The Performance of Model Ships in Restricted Channels in Relation to the Design of a Ship Canal, by R.S. Garthune, B. Rosenberg, D. Caffero, and C.R. Olson. Aug 1948. 242 pp., 136 figs.

602. The Effect of Bossing Design on the Effective Horsepower, Shaft Horsepower, and Wake for a Twin-Screw Passenger Vessel, Bethlehem Steel Design PR-1534, As Predicted from Tests with ModeI 3931, by M.S. Harper. Jun 1948. 31 pp., 23 flgs. Distributed only upon authorization of the Bethle hem Steel Co.

603. Experimental Investigation of the Type-2 Multifrequency Reed Gage for Recording Shock Motion, by B.J.W. Grier. Sep 1049. 29 pp., 10 figs.

604. See Report C-158.

605. Canceled.

606. (NE 051-427). Elastic Deformation of Thin Ellipsoidal Shells under Hydrodynamic Pressures, by Phill1p Eisenberg. JuI 1949. 26 pp., 10 figs.

607. Rudder Force Test of Model 3973 Representing United States Lines Liner, by S.H. Brooks and S.C. Gover. Jun 1949. 9 pp., 5 figs. Distributed only upon authorization of Newport News Shipbuilding and Dry Dock Company.

608. Operating Manual for the TMB Type 13A Strain Indicator and Associated Equipment, by L.D. Anderson. Jul 1949. $24 \mathrm{pp} ., 11 \mathrm{flgs.}$

609. Canceled.

610. Exploratory Tests on Small Steel Diaphragms Subjected to Noncontact Explosion Attack, by Charles T. Johnson. Apr 1949. 22 pp., 6 figs.

611. Damage-Distance Relations for Thin Steel Diaphragms 20 Inches in Diameter Subjected to Noncontact Underwater Explosions, by Charles T. Johnson. Apr 1949. 16 pp., 5 flgs.

612. Performance of the Mare Islend Vibrograph, by E.I. Cec1l, Jr. Jun 1948. 8 pp., 7 figs. 


\section{REGUIAR SERIES}

613. A Theoretical Study of the Multifrequency Reed Gage for Measuring Shock Motion, by Samuel Davidson and Emily J. Adams. Jul 1949. 86 pp., 43 figs.

614. The Jacklin Six-Component Recording Accelerometer and Its Performance, by Q.R. Robinson. May 1948. $12 \mathrm{pp}, 4 \mathrm{flgs.}$

615. Preliminary Report of the Liberty-Ship Serles for the American Towing Tank Conference, by M.S. Harper. Oct 1947. 17 pp., 4 figs.

616. Manual for Report Writing at the David Taylor Model Basin, by Anna Jesperson. Aug 1948. 41 pp., 2 figs.

617. The Use of Doubly Refracting Solutions in the Investigation of Fluid Flow Phenomena, by Benjamin Rosenberg. Mar 1952. 47 pp., 15 figs.

618. A Comparison of Resistance Tests in Two Basins of a 13-Foot Model of a Great Iikes Freighter, by Morton Gertler and Rachel Welch. Dec 1047. 23 pp., 5 figs. Distributed only upon authorization of Pittsburgh Steamship Co.

619. A Comparison of the Effect1ve Horsepowers of Two Designs of an ICVP Represented by Models 4031 and 4032, by C.J. Wilson. Dec 1947. 17 pp., 14 figs.

620. Model Tests to Determine the Effective Horsepower and Shaft Horsepower Characteristics of Federal Shipbuilding and Dry Dock Company Hull Design P.S. 788 with Altered Bow, by Isidore Goldman. Dec 1947. 21 pp., 16 figs. Distributed only upon authorization of Federal Shipbuilding and Dry Dock Co.

621. Analys1s of Modern Propelier-Pump Design, by W. Spannhake. Jun 1948. $28 \mathrm{pp} ., 10$ figs.

622. A Study of Slotted Tensile Specimens for Evaluating the Toughness of Structural Steel, by H.R. Thomas and D.F. Windenburg.

Not published as a TMB report. Complete results of the work were published in the Research Supplement of the Welding Journal. Apr 1948. pp 209-216.

623. Resistance Test Data for a Model of an 880-Foot Passenger Vessel U.S. Maritime Commission Design P5-S2-El, by Rachel S. Welch. Dec 1947. $4 \mathrm{pp}$., I fig. Distributed only upon authorization of U.S. Maritime Commission.

624. Canceled. 


\section{REGUIAR SERIES}

625. A New Condenser-Type Pressure Gage, by Dr. Thomas A. Perls. Jun 1949. 64 pp., 26 figs.

626. A Resonant-Bridge Carrier System for the Measurement of Minute Changes in Capacitance, by George W. Cook. Feb 1951. 41 pp., 23 figs.

627. An Elastic-Tube Gage for Measuring Static and Dynamic Pressures, by Edward Wenk, Jr. May 1048. 36 pp., 17 figs.

628. Apparent Slip and Tactical Diameters from Trials of a German "E" Boat, by Lt. (jg) W.C. Sadler, USN. Jan 1948. 2 pp., I fig.

629. Propulsion Tests of Model 3839 Representing U.S. Maritime Commission Design Cl-M-AV8, by A.Q. Aquino. Jan 1948. 3 pp. Distributed only upon authorization of U.S. Maritime Commission.

630. Results of Additional Experiments with a Model of the Revised G-60 Sled-Type Towing Target, by Jack Posner. Jan 1948. 12 pp., 5 figs.

631. Hydrostatic Pressure Test of the Submarine Rescue Chamber YRC-6, by John W. Day. Sep 1949. 14 pp., 8 figs.

632. Preparation of Data for Computation of Vertical Flexural Modes of Eull Vibration by Digital Process, by Alice W. Mathewson. Sep 1949. 13 pp., 8 figs.

633. Tests to Determine Strength of Safety Earnesses for A1rcraft Pilots, by G.B. Mayfield and Mary C. Crook. Oct 1948. 5 pp., 6 figs.

634. Effect of Skeg Design on the Power Characteristics of a Twin-Screw Passenger and Trailer Ship as Predicted from Tests with Models 4013, $-1,-2,-3$, by M.S. Harper. May 1950. 30 pp., 10 ilgs.

Distributed only upon authorization of Sun Shipbuilding and Dry Dock Company.

635. (NS 724-008). Eydrostatic Pressure Tests on Thin Rectangular Diaphragms 21 inches by 13-1/2 inches, by John W. Day. Mar 1951. 44 pp., 22 figs.

636. (NS 724-008). Hydrostatic Pressure Tests on Thin Rectangular Diaphragms 84 inches by 54 inches, by John w. Day. Apr 1951. 41 pp., 32 figs.

637. Hydrostatic Tests of Low-Pressure Bronze Valves and Fittings, by Clayton L. Pittiglio and James G. McGinley. May 1949. 18 pp., 7 figs. 
638. Hydrostatic Tests of High-Pressure Steel Valves and Fittings, by Clayton I. Pittiglio. May 1949. 10 pp., 6 figs.

639. Tests of a 20-Foot Model of a Proposed Twin-Screw Passenger and Trailer Ship to Determine Shaft Horsepower, by R.E. Frisby and C.J. Wilson. Mar 1948. 40 pp., 29 figs. Distributed only upon authorization of Sun Shipbuilding and Dry Dock Company. Supersedes Report 578.

640. Shallow-Water Effect on the Performance of Single-Screw Vessels of U.S. Maritime Commission Design, Determined from Resistance, Propulsion, and Sinkage Tests of Models, by W.H. Norley. Feb 1948. 31 pp., 21 figs. Distributed only upon authorization of U.S. Army Engineers.

641. Results of Additional Experiments with Models of the BuShips Design "A" Boat-Type and TMB Design Towing Targets, by R.M. Adler and Jack Posner. Mar 1948. 11 pp., 3 figs.

642. Welding Test 357 - Tensile Strength of Cladded and Uncladded Butt Welds Made in 60-Pound Special-Treatment Steel, by C.I. Pittiglio. Aug 1048. 7 pp., 3 figs.

643. Levels and Frequency Distribution of Noise in the Test Basins of the Devid W. Taylor Model Basin, by V.I. Chrisler and M.I. Lasky. Jun 1948. 11 pp., 14 figs.

644. The TMB Type AM-IA Direct-Coupled Amplifier for the Measurement of Slow Trensient Impuises, by W.S. Campbell. Sep 1948. 27 pp., 9 figs.

645. The TMB Type 5A Strain Indicator, by W.S. Campbell. Oct 1948. 46 pp., 19 figs.

646. Power and Flow Characteristics for the Bethlehem Steel Company 28,000Ton-Deadweight Single-Screw Tanker As Predicted from Tests with Model 4057, by M.S. Harper. Apr 1948. 15 pp., 14 figs. Distributed only upon authorization of Bethlehem Steel Company.

647. A Cavitation Method for the Development of Forms Having Specified Critical Cavitation Numbers, by P. Eisenberg. Sep 1947. 14 pp., 6 figs.

648. The TMB Type-15K160 Strain Indicator, by Henry B.O. Davis. Oct 1948. 33 pp., 18 figs.

649. Trials Conducted on a German R130-Class Mine Sweeper Equipped with Voith-Schneider Cycloidal Propellers, by E.T. Klemmer and P.K. Johnson. Dec 1948. 71 pp., 35 figs. 
650. Power Predictions of a Single-Screw Tanker for Union 011 Company, Models 418TW and 4l8Tw-1, by M.S. Harper. Aug 1950. 29 pp., 13 figs. Distributed only upon authorization of Union Oil Company.

651. (NS 724-004d). A Retract1on-Type Displacement Gage, by Thomas A. Perls, Ph. D. Mar 1950. 30 pp., 22 figs.

652. Information for Private Parties Desiring Ship Model Tests at the David Taylor Model Basin, by R.B. Couch. Sep 1948. 19 pp., 5 figs.

653. Power Characteristics for the Newport News Shipbuilding and Dry Dock Company 26,000-Deadweight-Ton Single-Screw Tanker as Predicted from Tests with Model 4075, by Comdr. P.G. Schultz, USN. Jun 1948. 21 pp., $15 \mathrm{flgs.} \mathrm{Distributed} \mathrm{only} \mathrm{upon} \mathrm{authorization} \mathrm{of} \mathrm{Newport} \mathrm{News} \mathrm{Shipbuilding} \mathrm{and} \mathrm{Dry} \mathrm{Dock} \mathrm{Co.}$

654. Design of a Multifrequency Reed-Type Shock Gage with an Inertia-' Operated Trigger, by Milton Martin and Paul Golvato. May 1949. $16 \mathrm{pp} ., 6 \mathrm{flgs}$.

655. The Calibration of the Department of Interior, Geological Survey Water Samplers, Models D-43 and D-47, by R.A. Ebner and T. G1bbons. Jun 1948. $20 \mathrm{pp} ., 5 \mathrm{flgs}$. Distributed only upon authorization of Department of Interior.

656. Comparison of Kort Nozzles and Open Screw Propulsion for a River Towboat Pushing a Barge Fleet in Shallow and Deep Water at Speeds up to 12 Miles per Hour As Determined from Model Tests, by W.H. Norley. Jul 1948. $39 \mathrm{pp} ., 23 \mathrm{figs.} \mathrm{Distributed} \mathrm{only} \mathrm{upon} \mathrm{authorization} \mathrm{of} \mathrm{Dravo} \mathrm{Corporation.}$

657. A Method for Converting the British (C) Coefficient Based on the Froude " $O$ " Values to a (C) Coefficient Based on the Schoenherr Frictional Formula, by M. Gertler. Jul 1948. 7 pp., 2 flgs. Rev. ed. Jun 1949. 7 pp., 2 figs.

658. Model Tests to Compare Characteristics of Alternate Sterns of a 110Foot Ex-Sub-Chaser, by F.S. Cauldwell. Aug 1948. $10 \mathrm{pp} ., 9$ figs. Distributed only upon authorization of Linton Rigg and Company.

659. Design and Development of the NAJ Beacon Mark 1 and Mark 2, by Robert P. H1II. Nov 1948. $24 \mathrm{pp}, 16 \mathrm{figs}$.

660. Scale Effect on Model Propellers, by J.G. Hill. Jul 1948. 8 pp., 3 figs. 
661. An Analysis of Cable and Housing Requirements for a Deep-Towed Body at High Speed, by Leonard Pode. Nov 1948. 9 pp., 1 fig.

662. Notes on Turbulence-Stimulating Devices Used for Model Tests at the David Taylor Model Basin, by R.B. Couch. Aug 1948. 9 pp., 1 fig.

663. The Determination of Frictional Resistance, by Dr. F.H. Todd. Aug 1948. 9 pp., 2 figs. Rev. ed. Mar 1049. 8 pp., 2 figs.

664. Fatique Tests of Grousers for Amphibian Tractors, by Glover B. Mayfield. oct 1948. $6 \mathrm{pp} ., 6 \mathrm{figs}$.

665. A Diaphragm-Type Gage for Measuring Low Pressures in Fluids, by Edward Wenk, Jr. Jan 1950. 17 pp., 4 figs.

666. Proposed Methods of Reducing the Cable Ioad and Tension of High-Speed Towing Targets, by John Plum. Sep 1948. 32 pp., 13 figs.

667. Resistance and Stability Tests of the Woods Hole Oceanographic Institution Current-Indicator Buoys, by R.A. Ebner. Nov 1948. 19 pp., 19 figs.

668. Water Tunnel Investigation of Steady State Cavities - A Progress Report Prepared for Presentation at the Seventh Underwater Ballistics Conference, by Phillip Eisenberg and Hartley I. Pond. Oct 1948. $20 \mathrm{pp}$, 8 figs.

669. Analysis of Comparative Model Tests of Aquaflow and Smooth Bottom Planing Hulls, by J.H. Curry and Jack Posner. Oct 1948. 40 pp., 29 flgs. Distributed only upon authorization of the Michigamme Syndicate, Bay City, Michigan.

670. The Measurement of Turbulence in Water - A Progress Report Prepared for Presentation at the Seventh Underwater Ballistics Conference, by M.s. Macovsky. Oct 1048. 18 pp., 9 figs.

671. Resistance and Propulsion Characteristics of the American Ship Building Company 660-Foot ore Carrier As Predicted from Tests with Model 4098, by W.H. Roundy. Nov 1948. $30 \mathrm{pp}$., $17 \mathrm{flgs}$. Distributed only upon authorization of The American Ship Building Company.

672. Evaluation and Ievelopment of Nolse-Isolation Mounts and Mount Materials, by Leo Rubinowitz. Dec 1c,48. $6 \mathrm{pp}$. 


\section{REGUIAR SERIES}

673. Single-Screw Tanker Project T5-S-DP1. Part 1 - Resistence and Propulsion Tests and Lines of Flow of NodeI 4042-1, by R.S. Wel.ch. Dec 1948. $12 \mathrm{pp} ., 3$ figs. Distributed only upon authorization of U.S. Maritime Commission.

674. Withdrawn.

675. Single-Screw Tanker Project T5-S-DP1. Part 2 - Resistance and Fropulsion Tests of Model 4042-2, by R.S. Welch. Jan 1949. 11 pp., I fig. Distributed only upon authorization of U.S. Maritime Commission.

676. Canceled.

677. Cance Ied.

678. Analysis of Standardization Trial Results for USS LSM458 Equipped with Kirsten-Boeing Cycloidal Propellers, by C.J. Wilson. Sep 1948. 15 $\mathrm{pp}$., $8 \mathrm{figs}$. Distributed only upon authorization of Bureau of Ships.

679. Withdrawn.

680. Instruction Manual for Resonant-Bridge Carrier System, Condenser-Type Pressure Gage, and Associated Equipment, by Thomas A. Perls, Richard W. Armstrong, and Charles W. Hoffman. Jun 1949. 41 pp., 16 figs.

681. (Aero 761)

682. Report of Model Tests of an Emergency Cargo Vessel Model 4ll7, by Lt. (jg) W.C. Sadler, USN. Feb 1949. 13 pp., 5 figs. Distributed only upon authorization of U.8. Maritime Commission.

683. Report of Model Tests of en Emergency Cargo Vessel Model. 4115, by Jack Posner. Jun 1949. $17 \mathrm{pp} ., 6$ flgs. Distributed only upon authorization of U.S. Maritime Commission.

684. Report of Model Tests of an Emergency Cargo Vessel Model 4133, by Lt. Comar. D. Furlong, USN. Apr 1949. $17 \mathrm{pp},, 6$ figs. Distributed only upon authorization of U.S. Maritime Commission.

685. Rolling Charecteristics of Model 3705 Representing USS BURTON ISIAND (AG88), by S.C. Gover. Feb 1949. $10 \mathrm{pp.,} 6$ figs.

686. Methods for the New Analysis of the Original Data for the Taylor Standard Series (Preliminary Report), by Morton Gertler. Feb 194. 43 pp., 18 figs. Superseded by Report 806. 


\section{REGULAR SERIES}

687. (NS 830-100). Tables for Computing the Equilibrium Configuration of

a Flexible Cable in a Uniform Stream, by Leonard Pode. Mar 1951. 222 pp., 7 figs.

Supplement (NS 830-100). Cable Function Tables for Small Critical Angles, by Leonard Pode, Ph. D. and Louis Rosenthal. Sep 1955. 109 pp., 2 figs.

688. Lighting Banks for a Subsurface Camera, by Harold A. Eggers. May 1949. $12 \mathrm{pp}, \mathrm{f}$ figs.

689. Effect of Transverse Curvature on Frictions. Resistance, by L. Landweber. Mar 1949. $10 \mathrm{pp}, 1 \mathrm{fig}$.

690. Vibration Survey of the USS MIDWAY (CVB4I) Conducted during Ship Trials of July and August 1947, by N.B. Jasper. Mar 1948. 44pp., 24 figs.

691. Resistance and Propulsion Characteristics of a 630-Foot Single-Screw Tanker As Predicted from Tests on Model 4121-1, by S.S. Hagara. Mar 1949. 10 pp., 5 Ilgs. Distributed only upon authorization of Sun Shipbuilding and Dry Dock Company.

Supplement A - Comparison of Resistance and Propulsion Characteristics of a 630-Foot Single-Screw Tanker Predicted from Tests on Model 41211 and Model 4121-2, by S.S. Hagara. Sep 1049. 21 pp., 11 figs. Diatributed only upon authorization of Sun Shipbuilding and Dry Dock Company.

Supplement B - Resistance and Propulsion Characteristics of a 630-Foot Single-Screw Tanker As Predicted from Tests on Model 4l21-3, by S.S. Hagara. Jun 1950. $11 \mathrm{pp} ., 4 \mathrm{figs.} \mathrm{Distributed} \mathrm{only} \mathrm{upon} \mathrm{authorization} \mathrm{of} \mathrm{Sun} \mathrm{Shipbuilding}$ and Dry Dock Company.

Supplement C - Resistance and Propulsion Characteristics of a 30,000 D.W.T. Single-Screw Tanker as Predicted from Tests on Models 412l-4 and 4121-5, by A. Hack. May 1953. 15 pp., 6 figs. Distributed only upon authorization of Sun Shipbuilding and Dry Dock Company.

692. A Six-Component Dynamometer for the Measurement of Forces and Moments on Models of Ship Appendages, by Phillip Eisenberg, Morris S. Macovsky, and Walter I. Stracke. May 1949. 18 pp., Il figs.

693. Performance of the Puget Sound Vibrograph, by Q.R. Robinson. Sep 1949. $10 \mathrm{pp}$., 4 figs.

694. (Aero 769) 
695. Powering Characteristics of a 290-Foot Ferry As Predicted from Tests with Model 4122, by M.S. Harper and G.R. Stuntz, Jr. May 1949. 18 pp., 6 figs. Distributed only upon authorization of Kindlund and Drake.

Supplement A - Powering Characteristics of a 290-Foot Ferry As Predicted from Tests with Model 4122, by J.G. Hill and M.S. Harper. Sep 10,49. $23 \mathrm{pp} ., 9 \mathrm{figs}$. Distributed only upon authorization of Kindlund and Drake.

Supplement B - Powering Characteristics of a. 290-Foot Ferry As Predicted from Tests with Model 4122, by M.S Earper. Mar 1950. 11 pp., 5 figs. Distributed only upon authorization of Kindlund and Drake.

696. Power Characteristics of a Proposed 30,000-Ton D.W. Tanker As Predicted from Tests on Model 4ll1-2, by S.S. Hagara. May 1949. 14 pp., 5 figs. Distributed only upon authorization of New York Shipbuilding Corporation.

Supplement A - Prediction of the Relative Performance of Three Propellers Tested on Model 4111-2 Representing a 30,000 DWT Single-Screw Tanker, by S.S. Hagara. Jul 1949. 19 pp., 9 figs. Distributed only upon authorization of New York Shipbuilding Corporation.

Supplement B - Power Characteristics of a Proposed 30,000-Ton D.W. Tanker As Predicted from Tests on Model 4lll-1, by S.S. Hagara. Jan 1950. $22 \mathrm{pp} ., 14 \mathrm{figs}$. Distributed only upon authorization of New York Shipbuilding Corporation.

697. Withdrawn.

698. Maneuvering Tests of Model 4013-1 Representing Twin-Screw Passenger Trailership (Preliminary Report), by C.R. Olson, Jun 1949. 14 pp., 10 figs. Rev. ed. Jun 19,49. 30 pp., 22 figs.

Distributed only upon authorization of Sun Shipbuilding and Dry Dock Company.

599. Vibration-Generator Survey of the USS NIAGARA (APA87), by Norman H. Jasper. Dec 1948. $18 \mathrm{pp} ., 16$ figs.

700. Measurement of Intensity of Turbulence in Water by Dye Diffusion, by M.S. Macovsky, W.I. Stracke, and J.V. Wehausen. 23 pp., $10 \mathrm{figs.}$ Nov 1952 second printing.

701. Powering Characteristics of a 528-Foot AKA Prototype As Predicted from Tests with Mode1 4144, by Rachel Welch. Aug 1949. 17 pp., 8 figs. Distributed only upon authorization of U.S. Maritime Commission.

702. Model 4146, 588-Foot Cargo and Passenger Vessel for Mississippi Shipping Company Designed by George G. Sharpe, by Rachel Welch and William Gustilo. Aug 1949. 18 pp., 8 figs. Distributed only upon authorization of George G. Sharp.

703. Power Characteristics of a Liberty Ship As Predicted from Tests with Model 3748-2, by W.H. Roundy. Aug 1949. 11 pp., 4 figs. Distributed only upon authorization of U.S. Maritime Commission. 


\section{REGUIAR SERIES}

704. (NS 870-001). A Theoret1cal and Experimental Investigation of a Dynamicelly Loaded Ring with Radial Elastic Support, by Edward Wenk, Jr., Dr. Eng. Jul 1950. 78 pp., 30 figs.

705. Selsmic Effects of Explosions in the Test Pond on Buildings and Test Facilities at the David Taylor Model Basin, by E.T. Habib and E. Wenk, $\mathrm{Jr}$. Unpublished. Reierence copy available only in TMB Reports Section.

706. (NS 712-065). Calculation of the Normel Vert1cel Flexural Modes of Eull Vibration by the Digftal Process, by Alice W. Mathewson. Feb 1950. 20 pp., 19 figs.

707. Service Tests of Experimental High-Speed Towing Targets Conducted off the Virginia Capes May 20 to 27, 1949, by John Plum. Sep 1949. 10 pp.

708. (Aero 732).

709. Transition Temperature of Ship Plate in Notch-Tensile Tests, by E.M. MacCutcheon, C.L. Pittiglio, and R.H. Raring. Jui 1950. 33 pp., 31 figs.

710. Analysis of Wave Resistance, by George F. Weinblum, D. Eng. Sep 1050. $110 \mathrm{pp} ., 40$ figs.

711. Theory of the Water Brakes Type "Foett1nger," by W. Spannhake. Sep 1950. $13 \mathrm{pp} ., 7 \mathrm{flgs}$.

712. On the Mechanism and Prevention of Cavitation, by Phillip E1senberg. Jul 1950. $75 \mathrm{pp} ., 37$ flgs.

713. (NS 880-019). An Experimental Investigation of the Hydrodynamic Forces on Stranded Cables, by Leonard Pode. May 1950. 20 pp., 5 figs.

714. The Effect of Propeller Design on Powering Characteristics of a TwinScrew Passenger-Cargo Vessel As Predicted from Tests with Model 3931-1, by M.S. Harper. Nov 1949. $26 \mathrm{pp} ., 12 \mathrm{figs}$. Distributed only upon authorization of Bethlehem Steel Company.

715. (NS 712-065). The Steady-State Response of a Ship Hull to a Simple Harmonic Driving Force Computed by a Digital Process, by Emily J. Adams. May 1950. 25 pp., 15 figs. 


\section{REGUIAR SERIES}

716. (Aero 772).

717. (NS 880-019). A Method of Determining Optimum Lengths of Towing Cables, by Leonard Pode. Apr 1950. 15 pp., 8 figs. Appendix 1, Mar 1956.

718. Tests of a Trochoidal Propeller - TMB Propeller 3078, by J.G. Hill. Feb 1950. $6 \mathrm{pp} ., 4 \mathrm{flgs}$. Distributed only upon authorization of Trochoidal Propeller Corporation

719. Mathematical Formulation of Bodies of Revolution, by L. Landweber and M. Gertler. Sep 1950. 70 pp., 13 figs.

720. (NS 711-110). Evaluation of Selected Shock Instruments, by Thomas A. Perls and Harry Li. Rich. Feb 1951. 64 pp., 56 figs.

721. (Aero 788).

722. Twin-Screw Passenger and Trallership Model 4013-4. Wake Survey in Way of Propeller and at Two Locations Aft, by M.S. Harper. Jul 1950. 6 pp., 3 figs. Distributed only upon authorization of Sun Shipbuilding and Dock Company.

723. (NS 724-001). A Bar-Magnet Velocity Meter, by Dr. Thomas A. Perls and Dr. Erich Buchmann. Feb 1951. 28 pp., 12 flgs.

724. (NS 715-086). Effects of Turbulence Stimulators on the Boundary Layer and Resistance of a Ship Model as Detected by Hot Wires, by John P. Breslin and Morris S. Macovsky. Aug 1950. 44 pp., 22 figs.

725. A Low-Frequency Electronic Integrator, by B.H. Harrison. Feb 1951. 31 pp., 15 flgs.

726. (NS 715-086). Progress Report on Research in Frictional Resistance. Sep 1950. Prepared for American Towing Tank Conference.

Note on Studies of the Resistance of Hydraulically-Rough Surfaces, by Phillip Eisenberg. 6 pp., 7 figs.

A Review of the Theory of the Frictional Resistance of a Smooth Flat Plate with Turbulent Boundary Layer, by L. Landweber. 8 pp., 2 flgs.

Effect of Transverse Curvature on Frictional Resistance, by W.M. Ellsworth, Jr. 2 pp. 


\section{REGULAR SERIES}

726. Contd.

The Boundary Layer and Drag of Bodies of Revolution, by P.S. Granvilie. $4 \mathrm{pp}$.

Recent Progress in Hot-Wire Measurement of Turbulence in Water, by M.S. Macovsky and W.L. Stracke. 7 pp., 3 figs.

Model Basin Turbulence, by M.S. Macovsky and J.P. Bresiin. 3 pp., 2 figs.

Effects of Turbulence Stimulation on the Boundary Layer and Resistance of a Ship Model As Detected by Hot Wires, by J.P. Breslin and M.S. Macovsky. $6 \mathrm{pp} ., 3$ figs.

Experimentation to Develop Sultable Methods for Stimulating Turbulent Flow about Ship Models, by R.B. Couch and W.B. Hinterthan. 11 pp., 1 fig.

A Study of Rods as Stimulators of Turbulence in Boundary Layers, by M.S. Macovsky and J.P. Breslin. 7 pp., 3 figs.

On the Acoustic Stimulation of Turbulence, by M. St.Denis. 7 pp., 2 figs.

727. The Drag and Shape of Air Bubbles Moving in Liquids, by Benjamin Rosenberg. Sep 1950. 26 pp., 14 figs.

728. Development of Wex Ship Model Manufacturing at the David Taylor Model Basin, by R.B. Couch. Aug 1950. 21 pp., 16 figs. Prepared for American Towing Tank Conference.

729. Skin Friction Resistance and the Effects of Surface Roughness, by F.H. Todd, Ph.D. Sep 1950. 15 pp., 1 fig. Prepared for American Towing Tank Conference.

730. Introductory Remarks to Discussion on Scale Effect on Self Propuision Factors, by R.B. Couch. Sep 1950. $6 \mathrm{pp}$. Prepared for American Towing Tank Conference.

731. Scale Effect on Self Propulsion Factors, by J.G. Hill. Sep 1950.

3 pp. Prepared for American Towing Tank Conference.

732. Comparative Cavitation Tests, by J.G. Hill. Sep 1950. 6 pp., 3 figs. Prepared for Americ an Towing Tank Conference.

733. Canceled. 


\section{REGULAR SERIES}

734. (NS 715-085). AGB 1 and 2, TMB ModeI 3705. Predictions of Performance with and without Ice Guards. Part 1 - Propulsion, by R.E. Fisher. Sep 1950. $14 \mathrm{pp}$., $10 \mathrm{flgs}$. Distributed only upon authorization of Bureau of Ships, Code 420.

735. 528-Foot AKA Prototype, U.S. Maritime Commission Design S-X-DY, Models 4152 and 4191. Power Predictions, by M.S. Harper and S.E. Lee. Oct 1950. $20 \mathrm{pp}$., 14 figs. Distributed only upon authorization of U.s. Maritime Administration. Supplement A - 528-Foot AKA Prototype, U.S. Maritime Commission Design S-X-DY, Models 4152 and 4I52-1. Effect of Bow Alteration upon EHP, by M.S. Harper. Oct 1950. 9 pp., 4 flgs. Distributed only upon authorization of U.S. Maritime Administration.

Supplement B - 528-Foot AKA Prototype, U.S. Maritime Commission Design S-X-DY, Models 4152 and 4152-2. Effect of Stern Alteration upon Power Predictions, by M.S. Harper and J.Z. McArdle. Jun 1951. 18 pp., 7 figs. Distributed only upon authorization of U.S. Maritime Administration.

736. (NS 73I-040). Bending, Compression, and Shear Tests of Three Samples of Flight Deck Planking, by Everett E. Johnson. Oct 1950. 30 pp., 6 fligs.

737. 450-Foot Twin-Screw Train Ferry, Models 4192-W, 4193-W, and 4194-1. Powering Characteristics as Predicted from Model Tests, by S.F. Lee. oct 1950. $27 \mathrm{pp}$., 16 figs. Distributed only upon authorization of Canadian Vickers Limited.

738. (NS 715-086). Experimental Boat-Hull Form Test Program, Scheme J, Model 4310. Resistance Characteristics, by J.H. Curry. Oct 1050. $36 \mathrm{pp}$., $16 \mathrm{flgs}$. Distributed only upon authorization of Bureau of Ships, Codes $452,422$.

739. (NS 712-064). Recent Developments in the Theory of Ship Vibration, by R.T. McGoldrick, A.N. Gleyzal, R.L. Hess, and G.K. Hess, Jr. Feb 1051. 56 pp., 4 figs. Revised Edition, Oct 1953.

740. (NS 715-086). Experimental Boat-Hull Form 'i'est Program, Basic Form, Model 4300. Resistance Characteristics, by Eugene P. Clement. Nov 1950. $28 \mathrm{pp}$., 14 figs. Distributed only upon authorization of Bureau of Ships, Codes $452,422$.

741. (Aero 795).

742. (NS 712-100). Calculation of Normal Modes and Natural Frequencies of Ship Hulls by Means of the Electrical Analog, by Edward Kapiloff. July 1954. 31 pp., 10 figs. 
743. The Development of a Turbulence Indicator for Liquids Ut1lizing Magnetic Induction, by A. Borden. Nov 1950. 8 pp., 2 figs.

744. (Aero 795).

745. (NS 715-085). AGB 1 and 2, TMB Model 3705. Predictions of Performance with and without Ice Guards. Part 2 - Maneuvering, by F.D. Bradley. Feb 195l. 10 pp., 5 figs . Distributed only upon authorization of Bureau of Ships, Code 420.

746. (Aero 797).

747. Seatrain (Sun SB and DD Co. Contracts 581 and 582). Effective Horsepower and Shaft Horsepower Predictions, Model 4340-W, by M.S. Harper. Jan 1951. 28 pp., 14 f1gs. Distributed only upon authorization of Sun Shipbuilding and Dry Dock Company.

Supplement A - Seatrain (Sun SB and DD Co. Contracts 581 and 582). Effective Horsepower and Shaft Horsepower Predictions, Model 4340-W, by M.S. Harper. May 1951. 9 pp., 4 figs. Distributed only upon authorization of Sun Shipbuilding and Dry Dock Company.

748. SS PENNSYIVANIA, Standardization Trial Analysis and Comparison with Model Test Results, by J.B. Hadler and C.J. Wilson. Jan 1951. 25 pp., 4 flgs. Distributed only upon authorization of Bethlehem Steel Company, Shipbuilding Division.

749. (INS 724-002). The Response of Simple Floating Targets to Underbottom Explosion Attack, by Dr. Erich Buchmann. Jun 1951. 36 pp., 23 figs.

750. SS ESSO SUEZ, Standardization Trial Analysis and Comparison with Model Test Results, by J.B. Hadler and C.J. Wilson. Jan 1951. 20 pp., 3 figs. Distributed only upon authorization of Newport News Shipbuilding and Dry Dock Company.

751. (NS 724-001). The Response of a Ball Crusher Gage, by George Chertock. Apr 1951. $11 \mathrm{pp} ., 1 \mathrm{fig}$.

752. (NS 715-084). A Method for the Calculation of the Turbulent Boundary Layer in a Pressure Gradient, by Paul S. Granville. May 1951. 48 pp. 17 figs.

753. Measurement of Propeller Induced Hydrodynamic Pressures on Hull of USS CHARIES R. WARE (DD865), by LCDR. W.N. Ginn and F.E. Frillman. Jan 1951. $20 \mathrm{pp}, 9$ figs. 


\section{REGULAR SERIES}

754. Instructions for the Preparation of Technical Instruction Minuals by Personnel of the Enfineering Divisions of the Industrial Department, by J.G. McGinley. Jan 1951. $12 \mathrm{pp}$.

755. Instructions for the Preparation of Engineering Reports by Personnel of the Engineering Divisions of the Industrial Department, by J.C. Boyle. Jan 1951. $8 \mathrm{pp}$.

756. (Aero 794).

757. (NS 715-086). Model Test Results and Predicted IHP for Scheme "L" Experimental Boat-Hull Form Test Progrem from Tests of Model 4312 , by J.H. Curry., Mar 1951. 28 pp., 15 flgs.

$D$ istributed only upon authorization of Bureau of Ships, Codes $452,422$.

758. (NS 715-084). The Wave Resistance of Bodies of Revolution, by Dr. Georg P. Weinblum. May 1951. 64 pp., 35 figs. (Appendix by J. Blum).

759. Fast Cargo Vessel (George G. Sharp Design V-2248). Effective Eorsepower and Shaft Horsepower Predictions, TMB Model 4342-W, by S.S. Hagara. Apr 1951. 19 pp., 9 figs. Distributed only upon authorization of George G. Sharp.

760. Performance of Waterproofing Compounds Applied to Electrical Resistance Strain Gages Subjected to Eydrostatic Pressure, by Peter M. Palermo. Dec 1954. $21 \mathrm{pp} ., 11 \mathrm{flgs}$.

761. (NS 751-084). The Axialiy Symetric Potential Flow about Elongated Bodies of Revolution, by L. Landweber. Aug 1951. 67 pp., 5 figs.

762. (NS 712-064). Determination of Hull Critical Frequencies on the Ore Carrier SS E.J. KULAS by Means of a Vibration Generator, by R.T. MCGoldrick. Jun 1951. 23 pp., 2 figs. (Appendix by E.H. Kennard).

763. Operating and Service Manual for the TMB Chronograph, by William M. Snyder. May 1951. $26 \mathrm{pp} ., 7$ figs.

764. (NS 715-086). Model Test Results and Predicted EHP for Scheme I, Experimental Boat-Eull Form Test Program, from Tests of Model 4309 , by Eugene P. Clement. Apr 1951. 29 pp., 14 figs. Distributed only upon authorization of Bureau of Ships, Codes $452,422$.

765. (Aero 795). 


\section{REGULAR SERIES}

766. (NS 713-219). Wave Effects in Isolation Mounts, by Mark Harrison and Alan 0. Sykes. May 1951. 99 pp., 41 figs. Revised Edition by Mark Harrison, A.0. Sykes and M. Martin. Oct 1952. 24 pp., 16 figs.

767. Transition Characteristics of Prestrained, Notched Steel Specimens in Tension, by E.M. MacCutcheon and W.A. Wright. Jan 1952. 20 pp., 13 figs.

768. Development of Water-Spout Scoop for the TMB Planing Float when Used as a Towed Position-Indicator, by R.A. Ebner. May 1951. 10 pp., 6 figs.

769. (NS 715-086). Model Test Results and Predicted EHP for Bureau of Ships Design 52-Foot Aircraft Rescue Boat from Tests of Model 4377, by J.H. Curry. Jun 1951. 23 pp., 18 figs. Distributed only upon authorization of Bureau of Ships.

770. (NS 713-065). Critical Pressures for the Inception of Cavitation in a Large-Scale Numachi Nozzle as Influenced by the Air Content of the Water, by S.F. Crump. JuI 1951. 22 pp., 8 figs.

771. SS INDEPENDENCE, Standardization Trial Analysis and Comparison with Model Test Results, by ICDR. W.E. Garrett, USN. Jun 1951. 22 pp., 3 figs. Distributed only upon author ization of U.S. Maritime Administration.

772. (NS 700-001). The Separation of Viscous Drag and Wave Drag by Means of the Wake Survey, by Marshall P. Tulin. IuI 1951. 13 pp., I fig.

773. (Aero 794).

774. (NS 731-037). Stresses and Deflections in Flat Rectangular Plates Under Dynamic Lateral Ioads Based on Iinear Theory, by Joshua $\mathbb{I}$. Greenspon. Apr 1955. 27 pp., 2 figs.

775. Power Predictions for a Prototype Emergency Cargo Vessel (U.S. Maritime Administration Design (3-S-DX) Models 4115-1, 4133-1, 4190W, by S.E. Lee and S.S. Hegara. Jun 1951. 33 pp., 26 figs. Distributed only upon authorization of U.S. Maritime Administration.

776. (NS 715-086). Model Test Results and Predicted EHP for Hacker Form Experimental Boat-Hull Form Test Program from Tests of Model 4315, by. Eugene P. Clement. Jun 1951. 28 pp., 12 figs.

Distributed only upon authorization of Bureau of Ships. 
777. (NS 731-037). The TNB Automatic Ship's Motion Recorder, by Norman H. Jasper. Oct 1951. 29 pp., ll figs.

778. (NSC 715-084). Technical Specification for Digital Data Recording and Transcribing System, by Frederick H. Imlay and Franklin Hawkins. Apr 1954. 157 pp., 33 figs.

779. (NS 820-100). The David Taylor Model Basin Micropressure Range, by P. Eisenberg, J.P. Craven, and J.A. Luistro. Jun 1957. 30 pp., 14 figs.

780. The Forces and Moments Acting on a Body Moving in an Arbitrary Potential Stream, by William E. Cumins. (Advance Copy) Sep 1952. 58 pp., 3 figs. FINAL EDINION - Jun 1953. 62 pp., 3 figs.

781. (NS 731-037). Study of the Strains and Motions of the USCGC CASCO at Sea, by N.H. Jasper. May 1953. 60 pp., 29 figs.

782. (NS 715-086). Model Test Results and Predicted EHP for Bureau of Ships Design 90-Foot Aircraft Rescue Boat from Test of Model 4375, by J.H. Curry. Jul 1951. 23 pp., $10 \mathrm{flgs}$. Distributed only upon authorization of Bureau of Ships.

783.

784. Investigation of Materials Developed for Adaptability to Wax Model Production, by W.J. Leonard. Oct 1951. 9 pp.

785. Buckling of Multiple-Bay Ring-Reinforced Cylindrical Shells Subject to Hydrostatic Pressure, by W.A. Nash. Apr 1954. 11 pp., 1 fig.

786. A Comparison of the Reciprocity and Interferometer Methods of Calibrating Piezoelectric Accelerometers, by E.J. Stowe. May 1954. $10 \mathrm{pp} ., 1 \mathrm{f1g}$.

787. Power Characteristics for U.S. Maritime Administration Tanker Design T5-S-2a, Model 4393W \& 4393-I, by M. S. Harper and J.Z. McArdle. Dec 1952. 25 pp., 12 flgs. Distributed only upon authorization of U.s. Maritime Adminiatration.

788. Canceled. 


\section{REGULAR SERIES}

789. (NS 700-001). Preliminary Report of Friction Plane Resistance Tests of Ant1-Fouling Ship Bottom Paints, by R.B. Couch. Aug 1951. I9 pp., 13 flgs.

790. Comments and Calculations on the Problems of the Condenser Scoop, by W. Spannhake. Oct 1951. 28 pp., 3 figs.

791. (NS 713-017). Report on Some New Developments in Noise Isolation Problems, by Mark Harrison, Ph.D. Apr 1953. $6 \mathrm{pp}$. , Distributed only upon authorization of Bureau of Ships.

792. Effect of Small Errors in Body Shape and Angle on Pressure Distribution and Cavitation Limits, by Phillip Eisenberg. Oct 195l. 17 pp., 3 figs.

793. (NS 643-028). Progress Report, Research on Min Injection Scoops and Overboard Discharges, by John P. Breslin and William M. Ellsworth, Jr. sep 1951. $32 \mathrm{pp}, 13$ figs.

794. A Manual for Waveform Analysis, by Allce W. Mathewson. Jan 1952. 26 pp., 24 figs.

795. The Moment Acting on a Rankine Ovold Moving under a Free Surface, by Hartley L. Pond. Nov 1951. 25 pp., 4 figs.

796. A Theoretical Analysis of the Dynamical Stability of Towed Models, by W.H. Roach. Nov 195l. $21 \mathrm{pp} ., 8 \mathrm{figs.}$

797. Techniques for Protecting and Waterproofing Resistance Wire Strain Gages, by Milis Dean, III. Mar 1956. 36 pp., 10 figs.

798. (NS 715-086). Model Test Results and Predicted EHP for the Huron-Eddy Company 85-Foot and 94-Foot Aircraft Rescue Boat Designs, by Eugene P. Clement. Oct 1051. $26 \mathrm{pp}$., $12 \mathrm{figs.} \mathrm{Distributed} \mathrm{only} \mathrm{upon} \mathrm{suthorizstion} \mathrm{of}$ Bureau of Ships.

799. Effective Horsepower Predictions for Maritime Administration Tarker Design PD 33, Model 4379w, by M.S. Harper and J.Z. McArdle. Dec 1951. $9 \mathrm{pp} ., 6 \mathrm{flgs}$. Distributed only upon authorizstion of U.s. Maritime Administrstion. 
800. (NS 731-037). A Determination of the Critical Load of a Column or Stiffened Panel in Compression by the Vibration Method, by E.E. Johnson and B.F. Goldhammer. Feb 1952. 17 pp., 8 flgs.

801. (NS 643-078). Testing Main Injection Scoops and Overboard Discharges in Restricted Channels, by Avis Borden, Ph. D. Jan 1952. 20 pp., 6 flgs.

802. (NS 715-102). An Experimental Investigation of the Drag and Shape of Air Bubbles Rising in Varlous Liquids, by W.L. Haberman and R.K. Morton. Sep 1953. 59 pp., 30 f1gs.

803. Investigations of Speed Effects and Interactions on a Thrust-Torsion Meter of a 5000 Pound, 1000 Pound-Foot Transmission Dynamometer, by G.J. Norman. Jan 1952. 16 pp., 10 11gs.

804. The Diffusion of Air in to a Pulsating Cavitation Bubble, by Leonard Pode, Ph.D. Mar 1955. 21 pp.

805. Dynamic Calibration of 35-HP Propeller Dynamometer, by G.L. Santore. Feb 1952. 12 pp., 8 flgs.

806. A Reanalysis of the Original Test Data for the Taylor Standard Series, by Morton Gertler. Mar 1954. 304 pp. Incl. figs., tables, and sppendices. Nay be obtained from the Government Printing office; for $\$ 3.50$, Catalog No. D211.9:806.

807. Power Predictions for American Ship Bullding Company Ore Carrier, Model 4098-1, by M.S. Harper and A.H. Weaver, Jr. Dec 1951. 30 pp. 24 figs.

808. (NS 712-100). A Theoretical and Experimental Study of Propeiler-Shaft Fallures, by Norman H. Jasper. Jul 1952. 69 pp., 28 figs. (NS 712-038). Second Printing, Aug 1953. 68 pp., 28 flgs.

809. On Hydrodynamic Masses, by Georg P. Welnblum, Dr. Eng. Apr 1952. 19 pp., 6 flgs.

810. (NS 712-064). Model Flow Studies Around Stern of U.S. Navy Fleet Tug ATF-163, Model 3531, by M.S. Harper and A.H. Weaver, Jr. Jan 1952 9 pp., 6 flgs. 
811. The Reciprocity Calibration of Plezoelectric Accelerometers, by Mark Harrison, A.0. Sykes, and Paul G. Marcotte. Mar 1952. 17 pp., 10 figs. Revised Edition with Supplement by E.J. Stowe and R.I. Bort. Aug 1953. 38 pp., 18 figs.

812. (NS 715-084). Preliminary Experimental Investigation of Slamming, by Victor G. Szebehely, Dr. Eng., and Semuel H. Brooks. Jul 1952. 17 pp., 6 figs.

813. (NS 731-037). Application of Statistics to the Presentation of Wave and Ship-Motion Data, by Alice W. Mathewson, Feb 1955. 27 pp., 10 figs.

814. A Sensitive Vertical Displacement Seismometer, by George W. Cook, Apr 1952. 58 pp., 26 flgs.

815. An Experimental Study of Single Bubble Cavitation Noise, by Mark Harrison, Ph.D., Nov 195221 pp., 11 figs. (Revised Edition)

816. (NS 712-100). Experiments with an Impact Vibration Damper, by R.T. McGoldrick. May 1952. 13 pp., 4 figs.

817. Effective Horsepower Predictions for Maritime Administration Tanker Design PD34, Model 4380W, by M.S. Harper and J.Z. McArdle. Jan 1952. $9 \mathrm{pp} ., 4$ figs. Distributed only upon authorization of U.s. Maritime Administration.

818. The Use of Helical Springs as Nolse Isolation Mounts, by Alan 0. Sykes. Feb 1952. 23 pp., 11 figs.

819. The Pitching Moment Acting on a Body of Revolution Moving under a Free Surface, by Eartley L. Pond. May 195220 pp., 1 fig.

820. (NS 715-086). Model Test Results and Predicted EHP for the Huron-Eddy Company Revised 94-Foot Crash-Rescue Boat Design, by E.P. Clement, Geo. B. Springston, Jr., and J.H. Curry. Mar 1952. 13 pp., 4 figs. Distributed only upon authorization of Bureau of Ships.

821. (NS 712-100). Vibration Machines at the David W. Taylor Model Basin, by a.R. Robinson. Jul 1952. 65 pp., 26 figs. 


\section{REGUIAR SERIES}

822. (NS 731-038). Tests of the Elastic Stability of a Ring-Stiffened Cylindrical Shell Model $B R-5(\lambda=1.705)$, Subjected to Hydrostatic Pressure, by Robert C. Slankard and William A. Nash, Ph.D. Nay 1053. $43 \mathrm{pp}, 32$ figs.

823. (NS 715-084). Hydrodynamics of Slaming of Ships, by V.G. Szebehely, Dr.Eng. Jul 1952. 38 pp., 9 figs.

824. An Electrolytic Tank Developed for Obtaining Velocity and Pressure Distributions about Hydrodynamic Forms, by A. Borden, G.L. Shelton, $\mathrm{Jr}$. , and W.E. Ball, Jr. Apr 1953. 32 pp., 13 flgs.

825. The TMB Torsionmeter Shaft System, by J. Rex Pinlott. Jul 1352. $29 \mathrm{pp}, 17 \mathrm{flgs}$.

826. (NS 731-038). Analysis of Stresses at the Reinforced Intersection of Conical and Cylindrical Shells, by Edward Wenk, Jr., Dr. Eng., and C.E. Taylor. Mar 1953. 23 pp., 4 figs.

827. (NS 712-100). A Theoretical Approach to the Problem of Critical Whirling Speeds of Shaft-Disk Systems, by Norman H. Jasper. Dec 1954. $37 \mathrm{pp}$., 7 figs.

828. (NS 715-102). Unsteady and Amplitude Effects on the Moment DerIvatives of a Prolate Spheroid, by V.G. Szebehely, Dr.Eng., and O.C. Niederer. Dec 1953. 26 pp., 7 figs.

829. The Determination of Effective Stress by Means of Small Cubes Taken from Photoelastic Models, by Joseph S. Brock. Sep 1052. 16 pp., 1 fig.

830. (Aero 714). Wind Tunnel Test of Multiple Ship Moorings. Part IIIDetermination of Air Loads on Multiple Ship Moorings for Destroyers, Submarines, Iiberty ShIps, and Escort Carriers, by M.E. Iong. Jul 1952. 91 pp., 31 figs.

831. (NS 715-102). Noise from Flow-Induced Vibrations in the M-115 Hydrophone, by H.M. Fitzpatrick and M.F. Harkleroad, Aug 1952. 10 pp., 5 figs. 


\section{REGULAR SERIES}

832.

833. (NS 715-084). Generalization of the Dimensionless Frequency Parameter in Unsteady Flows, by V.G. Szebehely, Dr. Eng. Nov 1952. 25 pp., 9 figs.

834. (NS 715-102). Steady Two-Dimensional Cavity Flows About Slender Bodies, by M.P. Tulin. May 1953. 30 pp., 7 figs.

835. (NS 715-102 - NR 062-094). Measurements of Nolse Radiated by Subsonic Air Jets, by H.M. Fitzpatrick and Robert Lee. Nov 1952. 25 pp., 9 figs.

836. (NS 724-012 - NS 731-038). Theory of the Forced Vibrations of a Ring With Radial Elastic Support Subjected to Uniform External Pressure, by Thomas E. Reynolds. Aug 1955. 14 pp., 3 figs.

837. (Aero 732). Wind-Tunnel Tests of Pressure Distribution on a 1/96-Scale Model of an Alrplane Eanger for Electronics Tests, by T.G. Reed. Oct 1946. 25 pp., 7 figs. Distributed only upon authorization of Bureau of Yards and Docks.

838. (NS 715-102). The Leminar Flow about Very Slender Cylinders in Axial Motion, Including the Effect of Pressure Gradients and Unsteady Motions, by R.D. Cooper and M.P. Tulin. Apr 1953. 35 pp., 4 figs.

839. (NE 091-010). Iarge Elastic Bending of Heavy, Unfform Cantilevers with Hydrodynamic Loading, by P. Elsenberg and I. Folger Whicker. Nov 1952. $26 \mathrm{pp}$., 20 figs.

840. Investigation of Wave Effects Produced by a Thin Body - TMB Model 4125, by Georg P. Weinblum, Janet J. Kendrick, and M. Allison Todd. Nov 1952. $16 \mathrm{pp}, 7$ figs.

841. (NS 715-086). Resistance of Model 4377 Representing a 52-Ft Alrcraft Rescue Boat Equipped with Propulsion Unit Underwater Housings, by George B. Springston, Jr. Oct 1952. 8 pp., 3 flgs. Distributed only upon authorization of Bureau of Ships. 
842. (NS 715-102). A Brief Survey of Progress on the Mechanics of Cavitation. An Addendum to DTMB Report 712, on the Mechanism and Prevention of Cavitation, by Phillip Eisenberg. Preliminary Copy Oct 1952. 40 pp., 6 figs. Revised Edition Jun 1053. 41 pp., 6 ilgs.

842A. (NS 715-102). Discussions and Author's Closure for a Brief Survey of Progress on the Mechanics of Cavitetion, by Phillip Eisenberg. Jun 1053. $14 \mathrm{pp}$.

843. Model Test Results and Predicted EHP for the Euron-Eddy Company 55Foot Rescue Boat Design from Tests of Model 4434, by Clifford I. Sayre, Jr. Oct'1 152 . $18 \mathrm{pp} ., 7$ figs. Distributed only upon authorization of Huron-Eddy Company.

844. Tests of Proposed Aircraft Securing Fittings for Carriers with Wooden Decks, by K.P. Arges. Jan 1953. 18 pp., 10 figs.

845. A Study of Compression Noise Isolation Mounts Constructed from Cylindrical Samples of Various Natural and Synthetic Rubber Materin.s, by Alan 0. Sykes. Oct 1,53. 64 pp., 60 figs.

846. Precision Electronic Navigation System, by Henry Carleton and Richard P. McGinnis. Aug 1951. 21 pp., 10 figs. (Formerly C-423)

847. The TMB Magnetic Micrometer MK II, by J. Rex Pimlott. May Io 53. $42 \mathrm{pp} ., 17$ figs.

848. A Report on PuIl Vibration Measurements Made on the SS BETEIEHEM and Vibration Generator Tests Made on the SS C.A. PAUL and the SS PFRE MARQUETTE 21 While in Service on the Great Iakes, by Fdward Kapiloff and John T. Birmingham. Mar 1053. 15 pp., 3 figs.

849. (NS 715-102). The Calculation of the Viscous Drag of Bodies of Revolution, by Paul S. Franvilie. Jul 1953. 49 pp., 7 figs.

850. (NS 715-069). Model Test Results and Predicted EHP for Experimental 65-Foot Ianding Craft (ICM) from Tests of Model 4416, by George $B$. Springston, Jr. Jul 1956. 14 pp., 9 flgs. Distributed only upon specific Bureau of Ships authorization. 
851. (NS 731-037). Stresses in a Photoelastic Model of a Bottom Longitudinal Connection at a Bulkhead in Navy Oflers, by Joseph S. Brock and Joseph P. Eder. Feb 1953. 15 pp., 9 figs.

852. Effective Horsepower Predictions for Maritime Administration PD50, Model 4464W, by P.C. Fien and M.G. Xylas. Aug 1053. 9 pp., 4 f1gs. Distributed only upon authorization of Maritime Administration.

853. Cold Brittleness in Notched Wide Plates of Ship Steel, by Captain Wendell P. Roop, USN (Ret.). May 1954. 166 pp., 14 figs.

854. The Deaeration of Wuter by a Sound Beam, by Leonard Pode, M.S. May 1953. 34 pg., 4 figs.

855. (NS 73i-038). General Instability of Ring-Stiffened Cylinders with Clamped Ends under External Pressure by Kendricik's Method, by Edmund I. Kaminsky. Jul 1054. 13 pp., I fig.

856.

857 .

858. (Aero 842). Wind-Tunnel Investigation of the Forces and Moments on Several Types of Bridge Models, by Arnold W. Anderson and Elmer T. Burgan. Aug 1953. 6 pg., 30 figs.

859. An Electronic Wave-Height Meusurlng Apparatus, by W.S. Campbell. oct 1553. $18 \mathrm{pp} ., 6$ flgs.

860. Design Deta1is of the IMMB Resonant-Bridge Carrfer System, by C.W. Hoffman. Nov 1953. 40 pp., 26 figs.

861. A Novel Type of Depth Control or Depth Recorder for Underwater Bodies, by F.F. Burroughs. Oct 2951. $8 \mathrm{pp} ., 4 \mathrm{figs}$. 
862. The Loss of Energy of a Propeller in a Locally Varying wake Field, by E. i. Lerbs, Dr. Inș. Nov 1353. 19 pp., 6 figs.

863. Bibliography on Shells and Shell-Like Structures, by William A. Nash, Fh.D. Nov 1954. $76 \mathrm{pp}$.

864. (NS 715-102). Wall Corrections for Flow About Two-and Three-Dimensional Symmetrical Bodies in Rectangular Channels of Infinite and Finite Lengths, by Avis Borden, Ph.D. Dec 1954. 38 pp., 9 figs.

865. (Aero Data Report 7). Wind-Tunnel Tests of a 1/4-Scale Model P-4X Radar Antenna, by R. Mutimer. Aug 1953. 12 pp., 5 figs.

866. (Aero Data Report 8). Wind-Tunnel Tests of a Full-Scale Plasecki H-2l Hellcopter Rotor Hub, by John J. Foster. Aug 1953. 13 pp., 6 figs.

867. (NS 715-102). A Meter for Continuous Indication of Dissolved Air in Water, by H.M. Fitzpatrick and M.F. Harkleroad. Oct 1954. $21 \mathrm{pp} ., 6$ figs.

868. (NS 715-102). Free Fleld Measurements of Sound Radiated by Subsonic Air Jets, by Robert Lee. Dec 1953. 17 pp., Il figs.

869. Powering Characteristics of a 576-Foot Tanker, Mode? 4436, by P.C. Pien. Apr 1053. $9 \mathrm{pp},, 6$ figs. Distributed only upon authorization of Sun Shipbuilding and Dry Dock Company.

870. (NS 731-038). Analysis fo Dlscountinulty Stresses Adjacent to a Central Circular Opening in a Hemispherical Shell, by G.D. Galletly, Sc.D. Jan 1954. 34 pp., 6 figs. Revised Edition May 1956. 34 pp., 7 figs.

871. Powering Characteristics of a 30,000 D.W.T. Single Screw Tanker, Model 4121-5, by P.C. Plen. Oct 1953. 12 pp., 9 flgs. Distributed only upon authorization of Sun Shipbuilding and Dry Dock Company.

872. The Propagation of Elastic Waves in a Plate, by Dr. Mark Harrison. Jan 1954. $15 \mathrm{pp} ., 4$ figs.

873. Canceled. 
874. Speed and Power Predictions for American Ship Building Company Hull 871 Represented by Models $4460 \mathrm{~W}$ and $4480 \mathrm{~W}$, by W.T. Potter. Oct 1653. $31 \mathrm{pp} ., 23 \mathrm{figs.} \mathrm{Distributed} \mathrm{only} \mathrm{upon} \mathrm{authorization} \mathrm{of} \mathrm{the} \mathrm{American} \mathrm{Ship}$ Building Company.

875. (NS 731-037). Preliminary Report of Struins and Motions of the SS ESSO ASHVILIE for the Perlod 24 August 1952 through 31 July 1953, by Norman H. Jasper. Oct 1953. 16 pp., 5 figs. Superseded by Report 960 .

876. (NS 731-038). Tests of the Elast1c Stability of a Ring-Stiffened Cylindrical She11, Model BR-4 (=1.103), Subjected to Hydrostatic Pressure, by Robert C. Slankard. Feb 1955. 73 pp., 46 figs.

877. Power Predictions for a Proposed Great Lakes Tanker, Model 4433, by W.T. Potter. Sep 1953. 9 pp., 6 figs. Distributed only upon the authorization of Wilson Transit Company.

878. (Aero Data Report 11). Wind-Tunnel Tests of Two 2/3-Scale Model "O"Type Kite Otters, by George A. Barmard. Oct 1953. 20 pp., 6 figs. Distributed only upon authorization of TMB Hydromechanics Laboratory.

879. Predicted Cavitation Characteristics for the MMB-EPH Strut Section Compared with Those for the Bureau of Ships Standard Strut Section, by M.S. Macovsky, W.I. Stracke, and J.V. Wehausen. Jan 1948. 7 pp., 4 flgs.

880. (NS 713-017). A Guide for the Selection and Application of Resilient Mountings to Shipboard Equipment, by Francis F. Vane. Jul 1954. 157 pp., 46 figs. Preliminary Edition. Distributed only upon specific Bureau of Ships authorization.

881. Canceled.

882. Canceled.

883. Slamming Due to Pure Pltching Motion, by M. Allison Todd. Jan 1955. $36 \mathrm{pp}$., $17 \mathrm{figs.}$

884. Strains and Deflections of Portable Evans Dunnage Members Installed on USS DIAMOND HEAD (AE? ), by John T. Birmingham. Dec 1953. 11 pp., 6 figs. 
885. (Aero 855). An Angle-of-Atteck and Angle-of-Yaw Indicator Using a Direct-Reading, Simple Strain-Gage Circuit on Sting Balances, by Robert B. Ormsby, Jr. Feb 1954. 18 pp., 5 figs.

886. A Systemat1c Evaluation of Michell's Integral, by Georg P. Welnblum. Jun 1955. 66 pp., 8 figs.

887. (NS 712-100). Meesurement of Motion and Thrust Variation of Main Propulsion System of USS FRED T. BERRY (DDE858), by Quentin R. Robinson. Jan 195\%. 8 pp., 2 figs.

888. (NS 715-068). Model Tests of the Effect of "Sweep Bydrofolls" on Ships' Bilge Keels, by C.G. Moody. Jan 1954. 10 pp., 3 figs. Distributed only upon the authorization of Bureau of Ships.

889. (NS 715-090). Roll Damping and Resistance Due to Rolling for Model 3878-2 Representing DD692-Class (Long Hull) Destroyers, by G.P. Stefun. Feb 1954. 21 pp., 11 figs.

890. A Design Approach to the Problem of Critical Whirling Speeds of ShaftDisk Systems, by Normen H. Jasper. Dec 1954. 39 pp., 11 flgs.

891. Vibration Generator Tests on IST 1156, by Quentin R. Robinson. Apr 1954. 13 pp., 6 figs.

892. (Aero 858). Wind-Tunnel Investigation of Air Loads on Human Beings, by Thomas J. Schmitt. Jan 1954. $60 \mathrm{pp} ., 11 \mathrm{flgs}$.

893.

894.

895. (NS 712-100). V1bration Generator Test on the USS NORTHAMPTON (ECIC-1), by John T. Birminghem. Feb 1954. 17 pp., 9 figs. 
896. (NS 715-102). A Method for Measuring the Damping of Surface Waves by Wave Absorbers, by Howard R. Reiss. Mar 1955. 33 pp., 3 figs.

897. Speed and Power Predictions for Landing Vehicle LVT P-X-2, Represented by Models 4502-1, 4498, and 4498-1, by S.S Hagara. Apr 1054. 22 pp., 17 figs. Distributed only upon authorization of Bureau of ships.

808. (NS 712-100). A Stable D-C Operational Amplifier, by Eenry B.0. Davis. liat 1954. 17 pp., 6 figs.

899. (NS 712-100). A Function Control Unit for Use with Bureau of Ships Analog-Computer BUSAC, by Henry B.0. Davis. May 1054. 21 pp., 16 figs.

900. (NS 715-086). Maneuvering Tests on Modei 3705 Representing TwinScrew Ice Breakers (AGB $I$ and 2) With Inward and Outward Turning Screws, by F.I. Bradley. Apr 1954. 6 pp. Distributed only upon authorization of Bureau of Ships.

901. Powering Characteristics for a 158-Foot Columbian River Gunboat, Model 4516, by W.B. Hinterthan. Mar 1954. 12 pp., 9 figs. Distributed only upon authorization of Todd Shipyards Corp.

902.

C03. Comparison of Two Sterns for SS SCHUYLER OTIS BLAND, by W.T. Potter. 8 pp., 5 figs. Distributed only upon authorization of U.S. Maritime Administration.

904. (Aero 859). An Inexpensive Analogue Computer For Solving Wind-Tunne? Strain-Gage Equations, by R.T. Patterson. Jun 1954. 39 pp., 14 fligs.

905. Cenceled.

906. (NS 712-100). Comparison Between Theoretically and Experimentally Determined Natural Frequencies and Modes of Vibration of Ships, by R.T. McGoldrick. Aug 1954. 20 pp., 2 figs. 
907.

908.

909. (NSS 712-100). The TMB Portable Calibrator for Vibration Transducers, by Francis F. Vane. Nov 1954. 14 pp., 7 figs.

910. Hydrodynamic Forces and Moments Acting on a Slender Body of Revolution Moving Under a Regular Train of Waves, by William E. Cummins. Dec 1954. 41 pp., 10 figs.

911. Observations of Stresses and Strains Near Intersections of Conical and Cylindrical Shells, by Matthew F. Borg. Mar 1956. 71 pp., 62 figs.

912. Turning Tests of Model 4382WA Representing ISD28 Class, by F.D. Bradley. Jul 1054. $10 \mathrm{pp} ., 2$ flgs. Distributed only upon authorization of Bureau of Ships.

913. Ships Slamming in Head Seas, by V.G. Szebehely, and M.A. Todd. Feb 1955. 82 pp., 45 figs.

914. Model Experiments on Slamming of a Liberty Ship in Head Seas, by V.G. Szebehely, and S.M.Y. Lum. Feb 1955. 24 pp., 15 figs.

915. A Method for Predicting the Torque of Semibalanced Centerline Rudders on Multiple-Screw Ships, by S.C. Gover and C.R. Olson. Nov 1954. 17 pp., 7 figs.

916. A Plan for Processine the Ships Parts Control Center Inventory Control on the UNIVAC, by Joe M. Foster and Viola D. Hovespian. Jun 1955. $215 \mathrm{pp}$.

917. Mobilization and Current Materiai Requirements for New Ship Construction, by J.M. Boyer, J.J. O'Connor, and M. Siegel. Oct 1954. 37 pp. incl. diagrs. 


\section{REGULAR SERIES}

18. (Aero 867). Wind-Tunne? Tests on a Bulwark Windshield for a DD927Class Destroyer, by G.R. Mutimer. Aug 1954. 21 pp., 10 figs.

919. An Approximate Method of obtaining Stress in a Propeller Blade, by William B. Morgan. Oct 1954. 23 pp., 6 figs.

920. (NS 715-102). The Planing Characteristics of a V-Shaped Prismatic Surface with 50 Degrees Dead Rise, by George B. Springston, Jr. and Clifford I. Sayre, Jr. Feb 1255. 31 pp., 13 figs.

921.

922. Resistance Tests on USMA Design 0-FG, Mode1 4483, by W.T. Potter. Sep 1954. 9 pp., 6 figs. Distributed only upon authorization of U.s. Maritime Administration.

323. Power Predictions for Proposed Ammunition Ships AE 21-22, Model 4521, by W.T. Potter. Sep 1954. 16 pp., 12 figs. Distributed only upon authorization of Bureau of Ships

924. Power Predictions at High Speed for EC2-S-CI Liberty Ship, Model 3748-2, by W.T. Potter. Sep 1954. 7 pp., incl figs. Distributed only upon authorization of U.S. Maritime Administration.

925. (NR 060-171). The Theoretical Dynamic Longitudinal Stability of a Constant-Iift Hydrofoil System, by Frederick H. Imlay. Dec 1954. $10 \mathrm{pp} ., 1 \mathrm{fig}$.

926. The Determination of Frequency Response from Test Results that are of Short Duration and not Precisely Periodic, by Leonard Pode, Ph. D. Jun 1955. 43 pp., @ figs.

927. (NS 712-100). Calculation of Torsional Critical Speeds of Electrically Driven Propulsion Systems with Flexibly Mounted Planetary Reduction Gears, by Alice W. Mathewson. Jun 1955. 19 pp., 2 figs.

928. Vibration-Generator Tests on the After Superstructure of Certain Vessels of the IST 1156 Class, by Carrol H. Kinsey. Dec 1954. 12 pp., 4 figs. 


\section{REGULAR SERIES}

929. Canceled.

930. Wax Model Construction at the David W. Taylor Model Basin, by Jacques B. Hadler and Werner $B$. Einterthan. Jun 1955. 21 pp., 17 figs.

931. Resistance Tests and Motion Observations on Mode 1 s in a Seaway, by Dr. F.H. Todd. Nov 1954. $10 \mathrm{pp} ., 12 \mathrm{flEs.}$

932. Open Water Test Series of a Controllable Pitch Fropeller With

Varying Number of Blades, by Williem B. Morgan. Nov 1554. 13 pp., 7 figs.

933.

934.

935. Tactical Trials of USS ICU 1466, by John C. Carpenter and George T. Sparks. Jan 1355. $11 \mathrm{pp} ., 6 \mathrm{flgs.} \mathrm{Distributed} \mathrm{only} \mathrm{upon} \mathrm{authorization} \mathrm{of} \mathrm{Bureau}$ of Ships.

936. (NS 712-100). The TMB Midget Vibration Generator and Applicaticns, by Francis F. Vane. Aug 1955. $27 \mathrm{pp} ., 10 \mathrm{flgs.}$

937. Temperature-Induced Stresses in Beams and Ships, by Norman F. Jasper. Jun 1955. 27 pp., 6 figs.

938. A General Purpose Electronic Multiplier, by Robert A. Meyers. Apr 1955. $41 \mathrm{pp} ., 22$ figs.

939. The Formulation of Potential Flow Frobiems in Terms of a Fredholm Integral Equation of the Second Kind and Integral Equation Methods for Conformal Mapping, by Leonard Pode, Ph.D. Mar 1956. 49 pp., 3 figs.

940. (NS 731-037). An Approxiration to the Plastic Deformation of \& Rectangular Plate Under Static Load with Design Applications, by J.E. Greenspon. Jun 1955. $24 \mathrm{pp} ., 6 \mathrm{flgs}$. 


\section{REGULAR SERIES}

941. Contra-Rotating Optimum Propellers Operating in a Radially Non-Uniform Wake, by E.W. Lerbs. May 1955. 30 pp., 3 flgs.

942. Propeller Pitch Correction Arising from Iifting Surface Effect, by Dr. H.W. Lerbs. Feb 1955. $19 \mathrm{pp} ., 4 \mathrm{flgs}$.

43. USS ICU 1466. Standardization Trial Anslysis and Fuel Consumption Curves, by C.J. Wilson and B.H. Burnside. Jan 1955. 9 pp., I fig. Distributed only upon authorization of Bureau of Ships.

944. (Aero Data Report 16). Wind-Tunnel Tests of Low-Aspect-Ratio Control Surfaces with Trallirg Edge to Wind, by H.R. Chaplin. Feb 1054. $12 \mathrm{pp} ., 3$ flgs.

94. (Aero Data Report 24). Wind-Tunnel Tests of Several 1/12-Scale Models of AN/TSQ Fiber Glass Shelters, by Donaid C. Ballentine. Oct 1954. $10 \mathrm{pp} ., 4$ figs.

946. Towing and Erection Tests of the McDermott Marine Structure, by Thomas Gibbons. Jan 1955. $19 \mathrm{pp}, 10 \mathrm{flgs.}$ Distributed only upon the authorization of J. Ray McDermott Co.

947. (NS 712-100). A Thoorem on Bending Stresses in Rotating Shafts, by R.T. McGoldrick. Jun 1955. 11 pp., 2 flgs.

9.48.

949.

950. Feasibility Studies of the Roll Stabilization of the USS BOSTON $(C A G-1)$, by Grant R. Hegen. Sep 1955. 59 pp., Il flgs.

951. 


\section{REGUIAR SERIES}

552. (NS 715-102). Time Constants and Frequency Response of Coated Hot Wires Used as Turbulence-Sensing Elements, by Avis Borden, PH.D. Jun 1957. $58 \mathrm{pp} ., 11$ figs.

953. (NS 715-102). Summary Report on the Development of a Hot-Wire Turbulence-Sensing Element for Use in Water by R.G. Stevens, A. Borden, and P.E. Strausser. Dec 1956. $20 \mathrm{pp} ., 4$ f1gs.

954. Vibration-Generator Tests of Main Thrust-Bearing Foundations on USS FORRESTAL (CVA59), by Carrol H. Kinsey. Mar 1955. 10 pp., 4 flgs.

955. (NS 712-100). Forced Vibrations of Beams and the Effect of Sprung Masses, by E.H. Kennard, Ph.D. Jul 1955. 17 pp., 4 flgs.

956. (Aero Data Report 27). Wind-Tunnel Tests to Determine Aerodynamic Forces and Moments on Ships at Zero Heel, by G.R. Mutimer. Mar 1955. 32 pp., 18 flgs.

957. (NS 715-102). The Measurement of Local Turbulent Skin Friction by Means of Surface Pitot Tubes, by E.Y. Hsu, Ph.D. Aug 1955. 22 pp., 6 flgs.

958. Strains and Deflections of the Portable Dunnage Members Installed on USS DIAMOND HEAD (AE19). (Second Evaluations), by John T. Birmingham. Jun 1955. $20 \mathrm{pp}$., $12 \mathrm{flgs.} \mathrm{Distributed} \mathrm{only} \mathrm{upon} \mathrm{authorization} \mathrm{of} \mathrm{Bureau} \mathrm{of} \mathrm{Ships.}$

959. A Transportation Simplex Algorithm for Machine Computation Based on the Generalized Simplex Method, by George Suzuki. Jun 1955. $19 \mathrm{pp}$.

960. (NS 731-037). Service Stresses and Motions of the ESSO ASHEVILIE, AT-2 Tanker, Including a Statistical Analysis of Experimental Data, by N.E. Jasper. Sep 1955. $49 \mathrm{pp} ., 10$ figs.

961. Conversion of LSD for Recovery of 57-Ft MSB'S at Sea, by C.G. Moody. Aug 1955. 13 pp., 3 flgs.

962. (Aero Data Report 29). Wind-Tunnel Tests of 1/4-Scale Models of the Original and Modified S-Type C Paravane, by Elmer T. Burgan. May 1955. 24 pp., 11 figs. 
063. (NS 715-102). Exploratory Investigation of the Turbulent Wakes Behind Bluff Bodles, by Ralph D. Cooper and Morton Lutzky. Oct 1255. 35 pp., 14 figs.

964. Vacuum Control, TMB Type 252-1A, by F.H. Kendal1, Jr. Apr 1055. 8 pp., 2 figs.

965. The DTMB Four-Channel Oscillograph Type 214. Design Details and Operating Instructions, by C.W. Hoffman. Oct 1055. 71 pp., 36 figs.

966. Characterist1c Curves and Blade Measurements of Commercial Small Boat Propeller Serles, by G.L. Ober. Nay 1955. 9 pp., 3 figs. Distributed only upon authorization of Bureau of Ships.

967.

668. (NS 715-086). Model Test Results and Prealcted EHP for the World War II and the MK2 ICP(I)'S, from Tests of Models 4388-1, 4553, and 4555, by P.K. Eleftherlades. Jun 1955. 37 pp., Incl 30 plates. Distributed only upon authorization of Bureau of Ships.

969. (NS 724-018). The Impulse Generated by an Underwater Expiosion as a Function of Time and Depth, by Erich Buchmann, Ph.D. Nor 1955. 15 pp., 4 figs.

970. Strength Tests of Aircraft Securing Fittings for CVA61, by Peter M. Palermo. Jul 1955. 16 pp., 9 figs.

971. (NS 715-086). Model Test Results and Predicted EHP for two Designs for the MF2 40-Ft AVR From Tests of Models 4520 and 4543, by Peter X. Eleftheriades. Aug 1955. 19 pp., 12 figs. Distributed only upon authorization of Bureau of Ships.

972. The Powering Characteristics of a Vehicle Cargo Ship (Roli on - Roll off), Model 4534, by John V. McArdle. Jul 1955. 14 pp., 10 flgs. Distributed only upon authorization of Bureau of Ships. 
973.

974. Powering Characteristics of a 25,000 Dead Weight Tons Tanker. Models 4542,4547 , and 4550 , by P.S Shaw. Jul 1955. 30 pp., incl. figs. Distributed only upon authorization of Bureau of Ships.

975.

976. (NS 731-037). Sea Tests of the USCGC UNIMAK. Part I - General Outline of Tests and Test Results, by Norman H. Jasper and John T. B1rmingham. Mar 1956. $41 \mathrm{pp} ., 16$ figs.

977. (NS 731-037). Sea Tests of the USCGC UNIMAK. Part 2 - Stat1stical Presentation of the Motions, Hull Bending Moments, and Slamming Pressures for Ships of the AVP Type, by N.H. Jasper, Dr. Eng., and R.L. Brooks, CDR, USN. Apr 1957. 47 pp., 13 flgs.

978. (NS 731-037). Sea Tests of the USCGC UNIMAK. Part 3 - Pressures, Strains, and Deflections of the Bottom Plating Incident to Slamming, by Joshua E. Greenspon. Mar 1956. 25 pp., 8 flgs.

979. Pressure Tank and Instrumentation Facilities for Studying the Strength of Vessels Subjected to External Hydrostatic Loading, by E.E. Johnson. Apr 1956. 12 pp., 11 figs.

980. Underway Vibration Survey of the Hull and Propulsion System of the USS DEAIY (DE1006), by Carrol H. Kinsey. Aug 1955. 10 pp., 2 figs.

981. Analysis of Stress in the Conical Elements of Shell Structures, by C.E. Taylor and E. Wenk, Jr. May 1956. 14 pp., 5 figs.

982.

983. Strain-Gage Balances for Ship Model Testing, by V.E. Benjamin, M. Dean, III, and J.E. Stern. Aug 1955. 20 pp., 7 flgs. 
Dnvid Taylor Model Basin. Roport 984.

A SIX CHANNEL BALANCING UNIT TYPE 1000-A FOR USE

WITH DC OPERATIONAL AMPLIFIERS, by Henry B.O. Davis.

Dec 1957. ii, 14p. incl. figs., refs. (Industrial Department

Research and Development Report) UNCLASSIFIED

A 6-channel balancing unit used to reduce drift in dc operational amplifiers is described. Although designed specifically for stabilizing the TMB Type 175-A amplifiers used in the Bureau of 984. Ships Analog Computer BUSAC, it may be used with any operational amplifier baving a differential input stage.

The use of this balancing unit has reduced amplifier drift in the BUSAC computer to a negligible quantity.

985. Static Tests on CW-177A/U Sonar Domes to Determine Adequacy of Structural Reinforcement, by Robert D. Short, Jr., Myron E. Iunchick, Ph. D., and Harry P. Rietman. Sep 1955. 22 pp., 14 figs. Distributed only upon authorization of Bure au of Ships.

986. (NS 715-102). A Procedure to Impart Specified Dynamfcal Properties to Ship Models, by Howard R. Reiss. Mar 1956. 10 pp., 1 fig.

987. Determination of the Motion of a Body from Measurements of Flow Ahead of the Body, by I. Landweber, Ph.D. and M.A. Todd. Apr 1956. 37 pp., 4 figs.

988.

989. (NS 715-086). Maneuvering and Turning Tests of Model 4531 Representing the Small Cargo Ship (Ice Strengthened) AKA, by F.D. Bradley and W.G. Surber, Jr. Sep 1955. 8 pp., 2 flgs. Distributed only upon authorization of Bureau of Ships.

990. (NS 711-105). A Graphical Method for the Analysis of Nonlinear Systems Under Arbitrary Transient Conditions, by Erwin H. Bareiss and Sterling C. Atchison. Mar 1957. 39 pp., 19 figs.

991. (NS 715-102). Effects of Various Linkage Ratios on the Free-Stream Eydrodynamic Characteristics of an All-Movable Flapped Rudder, by C.R. Olson. Sep 1955. 24 pp., 12 figs.

992. (NS 715-090). Turning and Maneuvering Tests of Model 4521 Representing the Ammunition Ship AE2l Class, by W.G. Surber, Jr. and S.C. Gover. Mar 1956. 18 pp., 4 figs. Distributed only upon authorization of Bureau of Ships. 
REGULAR SERIES

994.

995. On Slamming, by V.G. Szebehely, M.A. Todd, and S.M.Y. Lum. Jan 1956. 47 pp., 31 figs.

996.

997. (NS 731-038). An Experimental Investigation of the Shell-Instability Strength of a Machined, Ring-Stiffened Cylindrical Shell Under Hydrostatic Pressure (ModeI $B R-4 A$ ), by Arthur F. Kirstein and Robert Slankard. Apr 1956. 26 pp., 12 figs.

998. (NS 715-102). An Investigation of the Flow in the Region of the Rudder of a Free-Turning Model of a Multiple-Screw Ship, by W.G. Surber, Jr. Oct 1955. 13 pp., 4 f1gs.

999. Instruction Manual. Electrical Control System for Automatic Compensating Paravane Towing Winch, by J.R. Parce. Jan 1956. 57 pp., 11 figs.

1000. (NS 715-086). Turning and Maneuvering Tests of Model 4556 Representing the Cargo Ship (DOCK) (Ice Strengthened) MSTS-AKD-1, by W.G. Surber, $\mathrm{Jr}$. and F.D. Bradley. Sep 1955. 9 pp., 2 f1gs. Distributed only upon authorization of Bureau of Ships.

1001. (NS 715-086). Subtask 29. Turning and Maneuvering Tests of Model 4541 Representing MSTS Gasoline Tanker T-AOG (Ice Strengthened), by F.D. Bradley. Dec 1955. 10 pp., 2 flgs. Distributed only upon authorization of Bureau of Ships.

1002. (NS 715-086). Model Test Results and Predicted EHF for a Round Bilge 40-Ft Aircraft Rescue Boat Design from Tests of Model 4525, by Ulysses A. Pournaras and Peter Shermen. Nov 1955. 18 pp., 10 figs. Distributed only upon authorization of Bureau of Ships. 


\section{REGULAR SERIES}

1003. (NS 731-037). Investigation of Pressures on Keel Blocks During Drydocking of USS MIDWAY (CVA 4I), USS VAIIEY FORGE (CVS 45), and USS INTREPID (CVA 11), by Peter M. Palermo and Joseph S. Brock. Apr 19.56. $39 \mathrm{pp}, 21$ flgs.

1004. Poweling Characteristics of a 37,000 Deadwelght Tons Tanker, Model 4602, by P.C. P1en. Nov 1955. 9 pp., 7 figs. Distributed only upon authorization of Newport News Shipbuilding and Dry Dock Co.

Supplement A - Powering Characterlstics of a 37,000 Deadwelght Tons Tanker, Model 4602, by P.C. Pien and C.S. Baxter. Apr 1956. 9 pp., 6 tigs. Distributed only upon authorization of Newport News Shipbuilding and Dry Dock Co.

1005. Tests of Two Hirkkala Propellers, TMB Numbers 3513 and 3514 , by W.H. Norley. Nov 1955. $10 \mathrm{pp}, 6 \mathrm{flgs.}$. Distributed only upon authorization of Wirkkala Propeller Sales, Inc.

1006. (NS 715-102). Model Test Results for Saunders ABC Ships, Models 4505 and 4505-I, by CDR. E.R. Meyer, USN. Feb 1957. 43 pp., 32 figs.

1007. (NS 712-100). Vibration-Generator Tests of the Propeller Shaft of the USS FORRESTAI (CVA59), by Bruce M. Wigle. Jul 1056. II pp., 6 ilgs.

1008. A Cathode-Coupled Oscillator of High Stability, by Henry B.0. Davis. Feb 1956. 38 pp., 8 figs.

1000. Seaworthiness of Three Designs for a United States Coast Guard 160Ft. Water Patrol Craft, by George P. Stefun. Feb 1956. 30 pp., 19 IIgs.

1010. Standardization Requirements for Technical Reports, by R.E Lord. Dec 1955. 39 pp., 7 Iigs.

1011. (NS 712-100, NS 715-102). Vibration Generator Experiments on SS GOPHER MARINER, by J.T. Blrmingham and R.T. McGoldrick. Mar 1956. 19 pp., 20 flgs. 


\section{REGULAR SERIES}

1012. Determination of the Added Mass of the McDermott Marine Structure, by Wllliam M. Ellsworth, Jr. and Thomas Gibbons. Nov 1955. 22 pp., 8 figs. Distributed only upon authorization of J. Ray McDermott \& Co., Inc.

1013. Static Tests on CW30TU Soner Dome to Determine Adequate Structural Reinforcement, by Joseph F. Eibling and Robert D. Short, Jr. Feb 1956. $22 \mathrm{pp} ., 12$ flgs. Distributed only upon authorization of Bureau of Ships.

1014.

1015.

1016. Vibration-Generator Tests of Propulsion-System Elements on the USS TIMMERMAN (EAG152), by Anthony R. Paladino. Mar 1956. 13 pp., 5 figs.

1017. (NSM 681-023). An Evaluation of the Control Engineering Corporation Combined Depth, Trim Angle, and Course Indicator for Submarines, by J.W. Church and D.L. Greenberg. Jan 1956. 30 pp., 12 figs.

1018. Canceled.

1019. Response of a Simple Floating Structure to Underwater Explosion Attack, by Erich Buchmann. June 1957. 21 pp., 8 figs.

1020. (NS 731-037). Probability Distribution of Wave-Induced Eull Girder Stresses For a Destroyer Escort, Based on Sea Tests of USS FESSENDEN (DERI42), by J.E. Greenspon and B.M. W1gle. Apr 1956. 11 pp., 3 flgs.

1021. (NSC 712-100). Natural Frequencles in Air of Shaft Struts and Braces of the USS FORRESTAL (CVA59), by Carrol H. Kinsey. Jan 1956. 11 pp., 3 fligs. 
1022. (NS 715-102). Calculations for Hull Vibration of the SS GOPHER MARINER and Comparison with Experimentai Results, by Raymond T. McGoldrick. May 1956. 31 pp., 11 figs.

1023. Sonar Dome Cavitation Correlation Studies on USS TIMMERMAN (EAGI52), by M.S. Macovsky and R.J. Duerr. May 1956. 12 pp., 4 figs. FOR OFFICIAL USE ONLY.

1024.

1025.

1026. The Development and Evaluation of the TMB Knotmeter Type 205A, by Leo F. Fehlner and Thomas Gibbons. Jan 1056. 26 pp., 9 figs.

1027. Study of Hydrodynamic Parameters for Design of a Strut Sultable for Electromagnetic Rodmeter, by M.P. Burkart and M.S. Macovsky. Mar 1956. $20 \mathrm{pp} ., 10$ flgs.

1028. Vibration-Generator Tests of the Propulsion-System Reduction-Gear Unfts on the USS FORREST SHERMAN (DD931), by Anthony R. Paladino. Apr 1956. 15 pp., 5 figs.

1029. Underway Hull Vibration Survey of the USS PLYMOUTH ROCK (ISD 29), by Clayton L. Albright, Jr. May 1956. 11 pp., 2 flgs.

1030. Flexible Transport Theory Routines for Nuclear Reactor Design, by Erwin H. Bareiss. Dec 1956. 77 pp., 6 flgs.

1031. The Error Estimation in an Approximate Solution of an Ordinary SecondOrder Differential Equation, by Erwin H. Bareiss. Nov 1956. 37 pp., 10 figs .

1032. (Aero 893). Wind-Tunnel Tests to Determine Aerodynamic Forces and Moments on a 1/48-Scale Model SS563-Class Submarine Heeled in Beam Winds, by G.R. Mutiner. Feb 1956. 23 pp., 9 figs. 
1033. LCU 1466. Standardization Trial Analysis and Results of Spectal Maneuvering Tests, by James A. H1ggins. Feb 1956. 19 pp., 9 figs. Distributed only upon specific Bureau of Ships authorization.

1034. The Calculation of Goldstein Factors for Three, Four, Five, and Six Bladed Propellers, by A.J. Tachmindji and A.B. Milam. Mar 1956. 26 pp., 4 figs.

1035. Behavior of the Series 60, 0.60 Block Coefficient Model in Waves, by V.G. Szebehely, Dr. Eng. and S.E. Lee. May 1056. 13 pp., 4 figs. 1036.

1037.

1038. Vibration-Generator Tests of the Propulsion-System Reduction-Gear Unit on the USS DEALEY (DE1006), by Francis F. Vane. May 1956. 13 pp., 1 fig.

1039.

1040. (NS 715-102). The Dynamics of a Gravity Towing System, by Eoward R. Relss. July 1957. 51 pp., 3 figs.

1041. A Rapidiy Converging Solution of the Conformal Mapping Problem of Eydrodynamics, by Pode, L. Ph. D. Jul 1956. 19 pp., I fig.

1042. (NS 715-102). Gas Bubbles As Sources of Sound In Iiquids, by M. Strasberg. Apr 1956. 9 pp., 4 figs.

1043. Series Investigation of Slamming Pressures, by Margaret D. Bledsoe. Dec 1956. 87 pp., 64 figs. 


\section{REGULAR SERIES}

1044. USS RIGEL (AF 58). Results of Special Maneuvering Trials, Ly James A. Higgins. May 1956. 16 pp., 11 figs. Distributed only upon specific Bureau of Ships authorization.

1045. (NS 410-100). Evaluation of the Friez Piston-Type Depth Recorder Model 520, by Thomas Gibbons. May 1956. 14 pp., 7 figs. FOR OFFICIAL USE ONLY.

1046. (NS 715-062). Model EHP Tests of Two Designs of a 36-Ft. Hydrojet ICVP, by Feter M. Kimon. Aug 1956. 30 pp., 21 figs. Distributed only upon specific Bureau of Ships authorization.

1047. Fowering Characteristics of an Alaska Trainship, Model 4610, by P.C. Pien and M.G. Cavanaugh. May 1956. 15 pp., 13 figs. Distributed only upon specific authorization of George C. Sharp Co.

1048. (NS 321-002). Pressure Buildup Due to Burning in a Vented Chamber, by George Chertock, Ph. D. Jul 1957. 15 pp., 2 figs.

1049.

1050. (NS 712-100). Determination of Influence Coefficients as Applied to Calculation of Critical Whirling Speeds of Propeller-Shaft Systems, by B.M. Wigle and N.H. Jasper, Dr. Eng. May 1957. 19 pp., 4 figs.

1051. The Potential Problem of the Optimum Fropeller with Finite Hub, by A.J. Tachmindj1. Aug 1956. 21 pp., 6 figs.

1052. A 36-Inch Variable Pressure Water Tunnel, by W.F. Brownell. Jun 1C56. 60 pp., 33 figs. Prepared for American Towing Tank Conference.

1053. A Rotating Arm and Maneuvering Basin, by W.F. Brownell. Jul 1956. 73 pp., 40 figs. Prepared for American Towing Tank Conference.

105\%. A 51-Ft. Pneumatic Wavemaker and a Wave Absorber, by W.F. Browneil, W. .. Asling and W. Marks. Aug 1956. 45 pp., 23 figs. Prepared for American Towing Tank Conference.

1055. Behavior of a Proposed Oceanographic Research Vessel in Waves, by F. V. Reed. Aug 1956. 15 pp., 5 figs. 


\section{REGULAR SERIES}

1056. A Review of Developments and Research at the Hydromechanics Laboratory of the David Taylor Model Basin, 1953-56, by Dr. F.B. Todd. JuI 2956. $27 \mathrm{pp} ., 1 \mathrm{fig}$. Prepared for American Towing Tank Conference.

1057. Low Frequency Wave Analyzer - TMB Type 272-1A, by Charles C. Eckloff. Jun 1956. $17 \mathrm{pp} ., 6 \mathrm{flgs.}$

1058. Comparison of Face Cavitation on Model and Full Scale Propellers, by A.J. Tachrilidj1. Jul 1956. 15 pp., 8 flgs. Prepared for American Towing Tank Conference.

1059. Powering Characteristics of a Modernized Liberty Cargo Vessel, Model 4544, by S.E. Lee and A.E. Weaver. Jul is56. S pp., 7 figs. Distributed only upon authorization of U.S. Maritime Administration.

1060. Hull Vibration Investigation on SS GOPHER MARINER, by Raymond $T$. McGoidrick and Vito L. Russo. Jul 1956. $59 \mathrm{pp} ., 48$ figs.

1061. Pitch Reduction With Fixed Bow Fins on a Model of the Series 60 , 0.60 Block Coefficient, by Ulysses A. Pournaras. Oct 1956. 26 pp., 13 figs.

1062. (NS 731-038). Observations of Snap-Through Action in Thin Cylindrical Shells Under External Pressure, by A.F. Kirstein and Dr. E. Wenk, Jr. Nov 1956. $17 \mathrm{pp} ., 6$ figs.

1063. Skin Friction Formulations, by Paul S. Granville. Jul 1956. 6 pp., $1 \mathrm{flg}$. Prepared for American Towing Tank Conference.

1064. Report on Geosim Analysis According to Schoenherr Line, by W.B. Hinterthan, Jul 1956. 88 pp., 41 figs. Prepared for American Towing Tank Conference

1065.

1066. 


\section{REGULAR SERIES}

1067. Motions of the SS SILVER MARINER in a State 5 Sea, bJ N.H. Jasper and B.M. Wigle. Oct 1956. 29 pp., 12 figs.

1068. Propeller Dynamometer Instmumentation at the David Taylor Model Basin, by G.J. Norman, M.W. Wlison, and F.B. Bryant. Jul 1956. 38 pp., 20 figs. Prepared for American Towing Tank Conference.

1069. On the Status of Complex Wave Generation in Model Tanks, by W1Ibur Marks. Jul 1956. 25 pp., 11 figs. Prepared for American Towing Tank Conference.

1070. Scale Effects in Seaworthiness, by V.G. Szebehely, M.D. Bledsoe, and G.P. Stefun. JuI 1956. 43 pp., 18 figs. Prepared for American Towing Tank Conference.

1071.

1072 .

1073. (NS 731-038). The Weakening Effect of Initiai Tilt and Lateral Buckling of Ring Stiffeners on Cylindrical Pressure Vessels, by E. Wenk, Jr. and E.H. Kennard. Dec 1956. 28 pp., 6 figs.

1074.

1075. Maneuvering Tests of Model 4382-WA Representing the USS THOMASTON (ISD28), by C.R. Ols on and F.D. Bredley. Aug 1956. 24 pp., 6 figs. Distributed only upon authorization of Bureau of Ships.

1076. (NS 715-102). The Planing Characteristics of an Inverted V Prismatic Surface with Minus 10 Degrees Dead Rlse, by Peter M. Kimon. Mar 1957. $27 \mathrm{pp} ., 10$ figs. 
1077. The H1lbert Problem for an Airfoil in Unsteady Flow, by CDR Patrick Leehey, USN. Jan 1957. 35 pp., 3 figs。

1078. The Influence of Air-Filled Nuclel on Cavitation Inception, by M. Strasberg, Ph.D. Sep 1956. 25 pp., 6 figs. Revised Edition May 1957. 29 pp., 6 flgs. Prepared for American Towing Tank Conference.

1079 .

1080.

1081. Super-Cavitating Flow Past Bodies with Finite Leading Edge Thickness, by J.N. Newman. Sep 1056. 34 pp., 6 figs.

1082. (Aero Data Report 35). Wind-Tunnel Tests to Determine the Wind Resistance of a 1/62.5-Scale Waterline Model, USS PLYMOUTH ROCK (LSD29), by Herbert E. White and Gordon W. Bishop. Sep 1956. 12 pp., 4 figs.

1083.

1084.

1085. (NR 252-002). Effects on the Performance of the U.S. Navy ICVP of Adding Retractable Bow and Stern Extensions, by Eugene F. Clement and Ulysses A. Pournaras. Sep 1956. 17 pp., 6 figs.

1086. 
1087. Resistance and Propulsion Characteristics of a 160-Foot Patrol Vessel, by A.L. Beal. Oct 1956. 16 pp., 12 figs. Distributed only upon authorization of U.S. Coast Guard.

1088. Longitudinal Vibrations of Marine Propulsion-Shafting Systems, by J.R. Kane and R.T. MCGoldrick. Nov 1956. 63 pp., 37 figs.

108?. (NS 715-090). Maneuverability Characteristics of Various Types of Replenishment Ships, by W.G. Surber, Jr. and S.C. Gover. Jan 1957. 40 pp., 20 figs. Distributed only upon authorization of Bureau of Ships.

1090.

1092.

1092. Proceedings of Progress Report 1953-1956, Engineering and Development Division, Applied Mathematics Laboratory, Edited by Gordon D. Goldstein. May 1957. 53 pp., 27 figs.

1053. (NS 715-102). Analyzing the Stepless Planing Boat, by Eugene F. Clement. Nov 1956. 43 pp., 21 figs.

1094.

1095. (NS 715-069). Model Test Results and Predicted HHP for a Hard Chine 40-Ft ICP (I) from Tests of ModeI 4618, by Peter Sherman. Nov 1256. 20 pp., 11 figs. Distributed only upon specific Bureau of Ships authorization.

1096. 
1097.

1098. Reaneiysis of Data of NNSB\&DDC Report "RESEARCH AND TEST OF MAIN INJECTION SCOOPS AND OVERBOARD DISCHARGE", by J.P. Craven and M.S. Macovsky. Nov 1956. 14 pp., 2 flgs. Distributed only upon specific Bureau of Ships a uthorization.

1099.

1100. RDR 4 Instruction Manual, David Taylor Model Basin One-Dimensional, One-Group Transport Theory Routine No. 4 for Nuclear Reactor Design, by Charles W. Dawson and Erwin H. Bareiss. Dec 1956. 9 pp.

1101. Nuclear Reactor Calculations at David Taylor Model Basin, by Irwin H. Bareiss. Feb 1957. 31 pp., 24 figs.

1102.

1103. Powering Characteristics of a 20,000 Deadweight Ton Tanker, Models 4612 and 4612-1, by N.I. Ficken. Nov 1956. 11 Fp., 8 figs. Distributed only upon authorization of the Sun Shipbuilding and Dry Dock Company.

1104 .

1105. An Analysis of Approximative Methods for Fredholm's Integrel Equation of the First Kind, by Robert W. McKelvey. Dec 1956. $20 \mathrm{pp}$. 


\section{REGUIAR SERIES}

1107. The Measurement of Thrust Fluctuation and Free Space Osci-lating

Pressures for a Propelier, by A.J. Tachmindji, and M.C. Dickerson. Jah 1057. $34 \mathrm{pp}$., 18 figs.

1108. Results of Standardization, Tactical, and Rough Water Trials on Five Alrcraft Rescue Boats, by CDR E.R. Meyer, USN. Apr 1057. 67 pp., $27 \mathrm{flgs.} \mathrm{Distributed} \mathrm{only} \mathrm{upon} \mathrm{specific} \mathrm{Bureau} \mathrm{of} \mathrm{Ships} \mathrm{authorization.}$

1109. Powering Characteristics for a Coast and Geodetic Survey Ship, Models 4637 and 4638 by A.H. Weaver, Jr. and E.E. West. Jan 1957. 24 pp., $19 \mathrm{flgs.} \mathrm{Distributed} \mathrm{only} \mathrm{upon} \mathrm{a} \mathrm{thorization} \mathrm{of} \mathrm{the} \mathrm{Maritime} \mathrm{Administration.}$

1110. (NS 715-102). Measurement of Transition on a Sphere at High Reynolds Numbers, by E.Y. Hsu and M.S. Macovsky. Jun 1957. 14 pp., 7 figs.

David Toylor Model Basin. Roport 1111.

CALCULATION OF GOLDSTEIN FACTORS (AML PROBLEM

1111. 42.1-54), hy J.W. Wrench. Sep 1855. 25p. tables refs.

(Research sad development report. Reprint of Applied Mathemst.

ics Laborstory technicsl report 14) UNCLASSIFIED

David Toylor Model Basin. Report 1112.

1112. REPORT ON THE PROGRESS OF THE BUREAU OF SHIPS COMPUTER LABORATORY, by Harry Polechek. Fob 1956. 17p illus., grapha, diagrs. (Research and development report. Reprint of talk given at the Cbief's Council, Burean of Shipa, 7 February 1956. Applied Mathematica Laboratory technical report 16) UNCLASSIFIED

1113. (NS 715-102). Comparative Resistance Data for Four Planing Boat Designs, by Eugene P. Clement and Peter M. Kimon. Jan 1957. 19 pp., 10 figs.

1114. Tests of a Tibergias Reinforced Plastic Hydrofoil (BuShips Diamond Configuration) Constructed by Dymamic Developments, Inc., by Peter Sherman. Jan 1957. $20 \mathrm{pp}$., $17 \mathrm{flgs.} \mathrm{Distributed} \mathrm{only} \mathrm{upon} \mathrm{specific} \mathrm{Bureau} \mathrm{of} \mathrm{Ships}$ authorization.

1115. Towing Characteristics of a U.S. Rubber Sealdtank, by Wm. M. Ellsworth, $\mathrm{Jr}$. and Thomas Gibbons. Jan 1957. 13 pp., 5 figs. Distributed only upon authorization of United States Rubber Company.

1116. The Calculation of Propeller Induction Factors, AMI Problem 69-54, by J.W. Wrench, Jr. Feb 1957. $17 \mathrm{pp}$. 
1117. (NSB 715-090). Powering Predictions and Flow Studies for EAG 153-4 from Tests with Model 4414-1, by W. Hintherthan end R. Falls. Apr $1957.26 \mathrm{pp} ., 16$ f'igs. Distributed only upon specific Bureau of Ships authorization.

2118.

1119. (NS 712-100). Calculation of the Response of a Ship Hull to a Transient Load by a Digital Process, by Raymond T. McGoldrick. Mar 1957. 17 pp., 5 figs.

1220.

1121. Powering Characteristics, for an 18 knot Cargo Vessel, Model 4639, by A.H. Weaver, Jr. Mar 1957. 30 pp., 25 flgs. Distributed only upon specific authorization of Bethlehem Steel Company.

1122. (NS 715-102). The TMB Random Noise Generator, by James E. Edlund. Jun 1957. 17 pp., 8 figs.

1123.

1124. Effect of Propeller Pitch Changes on Torque Unbalance of Counterrotating Propellers, by Wm. B. Morgan. Mar 1957. 8 pp.

1125. (NS 715-102). MV THOMAS NELSON Standardization Trial Report, by J.C. Corpenter. Jun 1957. 8 pp., I fig.

Distributed only upon specific authorization of the U.S. Maritime Administration.

1126.

1127. 
David Tayler Model Basin. Ropont 1128.

TWO-DIMENSTONAL REACTOR SIMULATOR CODE FOR

UNIVAC INSTRUCTION MANUAL, by Ruth M. Davis (and others)

1128. July 1956. ii. 115p., tables. (Research and developmeat

report. Reprist of Applied Msthemstics Laboratory technical

report 18)

UNCLASSIFIED

1129.

1130. The Measurement of Oscillating Pressures in the Vicinity of Propellers

by A.J. Tachmindj1 and M.C. Dickerson. Apr 1957. 39 pp., 23 figs.

1131. Powering Characteristics for a Bulk Cargo Vessel, Model 4648, by A.E. Weaver, Jr. May 1957. 16 pp., 13 figs. Distributed only upon specific Gibbs and Cox, Inc. authorization.

1132.

1133.

1134. (NE 051-600). A Feasibility Study of Methods for Simulating by Static Forces the Nonuniform Hydrodynamic Pressures on Sonar Domes, by Myron E. Lunchick, PH.D., Joseph E. Elbling, and Robert D. Short, Jr. May 1957. $21 \mathrm{pp}, 11 \mathrm{figs.}$

1135.

1136.

1137. 


\section{REGULAR SERIES}

1138.

1139.

1140.

1141. The Calculation of the Clrculation Distribution for Propellers with Finite Hub Having Three, Four, Five, and Six Blades, by A. J. Tachmindj1, and A. B. Milam. Jun 1957. 42 pp., 12 figs.

1142.

1143.

1144 .

1145.

1146.

1147. 
TI 



\section{R- SERIES}

1. The Critical Strength of Fiat Plates Loaded in Shear, by John Vasta. Aug 1935. 9 pp., 5 figs.

3. U.S.3. PHOENIX - Noise Survey. May 1939. 12 pp., 5 figs.

4. U.S.S. BAGLEY (DD386), U.S.S. MUGFORD (DD389) - Report of Nolse Survey. May 1939. 7 pp., 2 figs.

6. U.S.S. BAGIEY (DD386), Full Scale Elastic Tests under Service Conditions. Jul 1939. $27 \mathrm{pp}$, 20 figs.

7. USS ST. LOUIS - Noise Survey. Aug 1939. 5 pp., 1 fij.

8. U.S.S. BAGLEY (DD386) ) - Second Noise Survey. Aug 1939. 3pp.

9. Tensile and Compressive Tests of Longitudinals of CL51 to 54 with and without Manholes. Aug 1939. 45 pp., 27 figs.

10. USS HUGHES (DD 410) - Noise Survey. Sep 1939. $5 \mathrm{pp}$.

12. USS IIAMMANN (DD412), USS ANDERSON (DD411) - Noise Survey. Oct 1939. 5 pp.

13. Strain Measurements on Airplane Crane - USS FELENA (CL50). Oct 1939. 7 pp., 4 figs.

14. USS MUSTIN (DD413) - Noise Survey. Oct 1939. 4 pp.

15. U.S.S. WICHITA (CA45) - Noise Survey. Nov 1939. 10 pp., 4 figs.

16. Tests of Modulus of Elasticity of Inconel and Corrosion-Resisting Steel for Periscope Tubes. Nov 1939. 4 pp., 2 figs.

18. A Report on the Comparison of Methods of Doweling Steel Rods into Existing Concrete, by Lt. (jg) Boyd S. Brooks, USNR. Nov 1939. 10 pp., 7 figs.

19. U.S.S. RUSSELI (DD414) - Noise Survey. Feb 1940. 4 pp.

20. Experiments on Riveted Joints - With Particular Regard to the Outer Row Spacing Needed to Prevent Z1gzag Rupture. Feb 1940. 44 pp., 35 figs.

21. U.S.S. ST. LOUIS (CL49) - Noise Survey. Feb 1940. 13 pp., 2 figs. 


\section{R- SERIES}

22. Natural Frequency of Skeg on USS WASHINGTON (BB56). Apr 1040. 5 pp., 4 figs.

23. U.S.S. LANG (DD399) - Noise Survey. May 1940. 24 pp., 11 figs.

24. Retardation of a Vessel after Launching. May 1940. $10 \mathrm{pp} ., 7$ figs.

25. Turning Tests with Model 3600 - Representing CI5I to 54. May 1940. 23 pp., 13 figs.

26. Strain Measurements on a Diesel Engine Frame under Static Load. Aug 1940. $4 \mathrm{pp}, \mathrm{f}$ fig.

27. U.S.S. AIABAMA - Launching Model - Description of Proposed Apparatus and Outline of Test Procedure. Oct 1940. 4 pp.

28. Deflections of Torpedo Tube Foundations on U.S.S. BUCK and U.S.S. O'BRIEN. Oct 1940. $12 \mathrm{pp} ., 7$ figs.

30. Resistance of Structures to Explosive Load. Nov 1940. $25 \mathrm{pp}$.

31. Notes on the Resistance of Rods, Cables, and Ropes in Water. Dec 1940. 4 pp., 2 figs.

33. Tension in a Cable Towing a Heavy Weight through a Fluia. Mar 194l. 4 pp., 2 figs.

35. Resistances of V-Bottom Motor Boats - Tests of Twenty Related Modeis, EMB Series 50, by Lan J. Wong and Anthony Suarez. Jun 1941. 270 pp., 116 figs. Report 153, Experimental Towing Tank, Stevens Institute of Technology, superseded by Report R-47.

36. Turning Tests of Self-Propelled Models of V-Bottom Motor Torpedo Boats (Tests of 3.23 Models only), by W.C. Hugl1, Jr. Jun 1941. 75 pp., 38 figs. Report 154, Experimental Towing Tank, Stevens Institute of Technology.

37. Orientation and Position of a Heavy Body Suspended in a Uniform Current by a Flexible Cable. Aug 1941. 13 pp., 6 figs.

39. A Photographic Study of Small-Scale Underwater Explosions. Aug 1941. 12 pp., 22 figs. 
41. Turning Tests of 25-Foot Model Motor Torpedo Boats, Model Nos. 10-G, II-G, and 12-G at Norfolk Navy Yard, June 20-24, 194l, by K.S.M. Davidson and W.C. Eugli, Jr. Aug 1941. 35 pp., 20 figs. Report 154-B, Experimental Towing Tank, Stevens Institute of Technology.

42. Stability of a Streamlined Body Falling Through a Fluid with Uniform Speed, by I. Landweber. Sep 1941. 4 pp., I fig.

43. The Effect of the Flow of Water through Condenser Scoops on the Resistance of a Destroyer Model, by C.E. Janes. Sep 1941. 10 pp., 13 flgs.

45. Flectronic Methods of Observation at the David W. Taylor Model Basin. Part 1 - Dynamic Actions in HulI Structure, by Ens. G. Robert Mezger. oct 1941. $23 \mathrm{pp} ., 12$ figs.

46. A Depth Charge Direction Indicator - Developed by D. Bancroft and G.W. Cook. Oct 194l. 8 pp., 3 figs.

47. Tests of Twenty Related Models of V-Bottom Motor Boats, EMB Series 50 , by K.S.M. Davidson and Anthony Suarez. Oct 1941. $68 \mathrm{pp} ., 61$ figs. Revised Edition, Mar 1949. 107 pp., 91 figs.

48. The Value of Mathematics in Research at the David W. Taylor Model Basin, by Dr. N. Minorsky. Dec 1941. 7 pp.

49. Torpedo Protection Systems - Preliminary Data on the Underwater Shock Wave. Dec 194I. $12 \mathrm{pp.,} 6$ figs.

50. Launching Data for the USS AUK (AM57) and Photographic Methods Used in Obtaining Them, by J.G. Thews. Dec 194l. 12 pp., 10 figs.

51. Electronic Methods of Observation at the David W. Taylor Model Basin. Part 3 - A Low-Frequency Transient Detector, a Depth Charge Direction Indicator, and an Electronic Voltage Regulator, by Ens. G. Robert Mezger. Dec 194l. $17 \mathrm{pp} ., 6$ figs.

53. The Strength of Rigid-Frame Knees, by Dr. D.F. Windenburg. Jan 1942. $14 \mathrm{pp} ., 27$ figs. A paper presented before the Washington Chapter of the American Society of Mechanical Engineera, 11 Dec 1941.

54. Electronic Methods of Observation at the David W. Taylor Model Basin. Part 2 - Measurements of Steady and Alternating Stresses in Rotating Shafts, by W.F. Curtis and W.J. Sette. Jan 1942. 12 pp., 3 figs. 


\section{R- SERIES}

56. Tentative Roughness Allowances for 1942 for Use with the Schoenherr Friction Formula. Mar 1942. 3 pp., 1 fig. Superseded by TMB 576.

57. 5-Inch 38 Caliber Gun Foundations on Destroyers - Progress Report Descrıbing Results of Tests during Structural Gun Firing Trials of USS EIIYSON (DD454). Mar 1942. $3 \mathrm{pp} ., 1 \mathrm{fig}$.

62. Electronic Methods of Observation at the David W. Taylor Model Basin. Part 4 - An Acoustic Analyzer, by Ens. R.W. Roop, USNR. May 1942. $40 \mathrm{pp} ., 24$ figs.

63. Test of Rigid-Frame Models - Progress Report, Comdr. W.P. Roop, USN. Jul 1942. 9.pp., 6 figs.

65. Explanatory Notes to Accompany Motion Pictures of Underwater Explosions. Aug 1942. $5 \mathrm{pp}$.

66. Photographic Methods of Recording Behavior of Steel Diaphragms under Explosive Ioad, by Lt. D.C. Campbell, USNR, D. Bancroft, and B.I. Milier. Aug 1942. $6 \mathrm{pp}$., 5 figs.

68. Iift of Various Devices for Leveling a Long Cylinder Towed through a Fluid, by L. Landweber. Sep 1942. 6 pp., 5 figs.

69. USS AIABAMA, Launching Calculations. Sep 1942. 18 pp., 4 figs. Norfolk Navy Yard Report.

70. Investigation of Failure of Welded Structure in the USS CURTIS (AV4), by J.W. Day. oct 1942. 15 pp., 8 figs.

72. Minutes of the 1942 Annual Meeting of the American Towing Tank Conference, by Capt. H.E. Saunders, USN. Oct 1942. 8 pp.

74. Compression Tests of Formica Grade BM and Formica Grade R. Nov 1942. 4 pp., 2 figs.

76. Launching Model Tests of the USS NEW JERSEY (BB62) - Preliminary Report. Nov 1942. $27 \mathrm{pp} ., 30$ figs.

77. Photographic Studies of Shock Waves in Water, by Lt. D.C. Campbell, USNR. NOv 1942. $15 \mathrm{pp} ., 19$ figs. 


\section{R- SERIES}

78. Electronic Methods of Observation at the David W. Taylor ModeI Basin. Part 5 - A Self-Stabilizing Amplifier, by Lt. G. Robert Mezger, USNR. Jan 1943. 5 pp., 2 figs.

79. Electronic Methods of Observation at the David W. Taylor Model Basin. Part 6 - The Application of Frequency Deviation Methods to Measurements of Mechanical Changes, by Dr. Ermst Plesset. Feb 1943. 23 pp., 18 figs.

80. Characteristic Curves for Planing Surfaces, by $I$. Landweber and P. Eisenberg. Jan 1943. 6 pp., 5 figs.

81. An Annotated Bibliography of Cavitation, by F.A. Raven, Ph.D., A.M. Feller, and Anne Jespersen. Dec 1947. 205 pp.

83. Air-Bubble Generators, by J.J. Donoghue. May 1943. 18 pp., 12 figs.

85. Alternating Torque Tests on a Turbine Shaft - U.S. Destroyer MOFFETT, by W.F. Curtis. May 1943. 9 pp., 9 figs.

86. Electronic Methods of Observation at the David W. Taylor Model Basin. Part 7 - A Stable Direct-Coupled Amplifier, by Lt. G. Robert Mezger, USNR. Mar 1943. $17 \mathrm{pp} ., 8$ figs.

99. Stopping and Backing Trials of a Destroyer, from Tests on USS ROE (DD4I8). Aug 1940. $28 \mathrm{pp}$.

106. Welding Test No. 170 - Investigation of Welded Butts and Seams in S.T.S. Subjected to Ballistic Impact - Report of Tensile and Bend Tests, by J.W. Day. Apr 1939. 13 pp., 15 figs.

107. Welding Test No. 175 - An Investigation to Determine the Value of the Bond between Cladding and Plate of Nickel-Clad Plate when Welded, by J.W. Day. Apr 1939. 10 pp., 5 figs.

108. USS SOUTH DAKOTA (BB57) - Tests to Determine Efflcacy of Welding Procedure, by E.E. Johnson and J.W. Day. Jun 1939. 9 pp., 3 figs.

109. Welding Test No. 178 - An Investigation to Determine the Physical Properties of CRS Jolnts Welded with Grade EA Electrodes, by J.W. Day. Jun 1939. $7 \mathrm{pp}$., 4 figs. 


$$
\text { R- SERIES }
$$

110. Welding Test No. 171 - Effects of Welding on the Properties of STS, by J.W. Day. Aug 1939. 8 pp., 5 figs.

111. USS SOUTH DAKOTA (BB57) - Experimental Thermit Welding of Iower Roller Tracks - Static Tensile Test, by J.W. Day. Aug 1939.6 po., 3 figs.

112. Welding Test No. 184 and helding Test No. 185 - An Investigation to Determine the Physical Properties of welded STS Butt joints, by F.F. Vane. Dct 1939. $12 \mathrm{pp} ., 10 \mathrm{figs}$.

113. Welding Test No. 180 - High Tensile Steel - The Tensile Strength of Weided. Jolnts with Eigh Width-Thickness Ratios, by J.W. Day and F.F. Vane. Dec 1939. 33 pp., 38 figs.

114. Welding Test No. 161 - Investigation to Determine the Influence of WeldIng on Figh Tensile Steel - High Tensile Steel, Chemcial and Physical Properties, by F.F. Vane and M.T. Sniffin. Nov 1939. 2 pp.

115. Welding Test No. 170 (Supplement) - Investigation of Welded Butts and Seams in STS Subjected to Ballistic Impact - Report on Tensile Tests of Cladded Specimens, by J.W. Day and F.F. Vane. Nov 1939. 6 pp., 4 figs.

116. Welding Test No. I9l - An Investigation to Determine the Fhys1cal Properties of Fartially Grooved Tee Joints Made with Grade EA Electrodes Tension, Shear, and Bend Tests, by F.F. Vane and M.T. Sniffin. Nov 1939. $10 \mathrm{pp}$., 4. I'igs.

117. Velding Test 194 - STS Cylinders Subjected to Explosive Impact, by J.W. Day. Mar 1940. 28 pp., 20 figs.

118. Welding Test 194 (Supplement) - STS Cylinders Subjected to Explosive Impact, by J.W. Day. May 1940. 8 pp., 5 flgs.

119. Welding Test 196 - Tensile Strength of Welded Jolnts in Special Treatment Steel with 25-20 Electrodes, by J.W. Day. May 1940. 42 pp., 34 figs.

120. Welding Test 183 - Forty-Pound Special Treatment Steel under Tee Bend, by J.W. Day. Jun 1940. 10 pp., 9 figs. 


\section{R- SERIES}

121. Welding Test 171-A - The Effect of Welding on the Physical Properties of Special Treatment Steel, by J.W. Day. Apr 1,4l. 11 pp., 11 figs.

122. Welding Test 206 - Physical Characteristics of Welded Longitudinal Seams - Preliminary Investigation, by J.W. Day. Apr 1941. 6 pp., 6 figs.

123. Welding Test 207 - Tensile Strength of Butt Welds Made in 40 -Pound Special Treatment Steel, by J.W. Day. May 194l. 37 pp., 35 figs.

124. Welding Test 238 - Scalloped Grooved Butt Joints in Special Treatment Steel, by J.W. Day. Aug 194l. 5 pp., 7 figs.

125. Welding Test 194 - STS Cylinders Subjected to Explosive Impact (Second Supplement), by J.W. Day. Jan 1942. 16 pp., 12 figs.

126. Welding Test 220 - Welded Butt Straps in Special Treatment Steel Static Tensile Tests, by J.W. Day. Maj 1942. 16 pp., 39 figs.

127. Analysis of a Cylindrical Gun Foundation under Axial Loading, by Edward Wenk, Jr. Apr 1943. 10 pp., 6 figs.

128. Preparation, Labeling, and Identification of Graphs and Figures. Jun 1943. $14 \mathrm{pp} ., 12$ figs.

129. Welding Test 206 - Physical Characteristics of Welded Iongltudinal Seams, by J.W. Day and Comdr. W.P. Roop, USN. Mar 1943. 29 pp., 37 figs.

130. Test of Stabilizing Vanes to Reduce Rolling of Ships - Proposed by Thomas A. Edison. Mar 1918. $12 \mathrm{pp} ., 6$ figs.

Distributed only upon authorization of the administrators of the estate of Thomas A. Edison.

131. Report of Test of System of Using an Air Film on the Shell Plating of a Ship to Reduce Frictional Resistance - Proposed by W.H. Fauber. Apr 1918. $10 \mathrm{pp} ., 4 \mathrm{figs}$. Distributed only upon authorization of the administrators of the estate of W.H. Fauber.

132. Tests of Partially Submerged Propellers of the Sea-Sled Type. Apr 1919. $13 \mathrm{pp} ., 4$ figs.

133. Test of Vertical Steering Control of Submarine S-3 Using Various Stern Horizontal Rudders, From Experiments with Model 1966. Apr 1919. 6 pp., 3 figs. 
134. Test of Vertical Steering Control of 1600 Ton Submarine - Scheme D from Experiments with Model 2214. May 1919. 6 pp., 4 figs.

135. Test of Vertical Steering Control of 1600 Ton Fleet Submarine - Scheme E - from Experiments with Model 2217. Jul 1919. 6 pp., 4 figs.

136. Test of Vertical Steering Control of U.S. Submarines $0-3$ to $0-10$ from Experiments with Model 2035. Aug 1919. 7 pp., 4 figs.

137. Test of Vertical Steering Control of 1750 Ton Fleet Submerine - Scheme K - from Experiments with Model 2243. Aug 1919. 7 pp., 4 figs.

138. Test of Vertical Steering Control of U.S. Submarines $548-51$ and S159162 from Experiments with Model 2229. Nov 1919. 6 pp., 4 figs.

139. Comparison of Power and Speed Data for USS NEW MEXICO on Standardization Trials with Results of Self-Propelled Model Tests. Nov 1919. 8 pp., 4 figs.

140. Mechanical Integration of Ordinary Differential Equations by Means of Dynamical Analogues, by Dr. N. Minorsky. Jan 1941. 62 pp., 29 figs.

141. Static Torsion Test of a Centrifugally Cast Steel Shaft, by E.E. Johnson. Aug 19,43. 8 pp., 4 figs.

142. Plastic Strain and Deflection Tests on Clamped Circular Steel Plates 20 Inches in Diameter, by Dr. A.N. Gleyzal. May 1944. 41 pp., 48 figs.

143. Sweep Wire Passing Device for Mine Mooring Cables, by Comdr. G.L. Sraith, USNR, and K.H. Wilcoxon. Mar 1943. 15 pp., ll figs.

146. Superseded by C-297.

149. Initial Turning Movements - USS CIMMARRON (AO22) - Representative of Auxiliary Class A022 to 32 and Auxiliary Class ACV26 to 29. Jun 1943. $17 \mathrm{pp}$.

152. A Study of Wakes Behind Reduced Sections of Submarine Periscopes, by M. Kirstein. May 1943. 56 pp., 44 figs. 


\section{R- SERIES}

154. Dynamic Strain Measurements in the Crankshaft of a Diesel Engine, by W.F. Curtis. Oct 1943. 12 pp., 15 figs.

157. A Tourmaline Crystal Gage for Underwater Explosion Pressure, by A.R. Cohen and B. Stiller. Dec 1943. 7 pp., 8 figs.

160. Tactical Curves - Minesweeper AM82 Class. Oct 1943. $21 \mathrm{pp}$. Prepared by Experimental Towing Tank, Stevens Institute of Technology.

165. Tactical Curves for Minesweepers AM57 Class - AM57-65, 100-131, 314-320, 322-324, and 340-341. Dec 1943. 21 pp. Prepared by Experimental Towing Tank, Stevens Institute of Technology.

166. Tactical Curves for Minesweepers AMI36 Class - AMI36-165 and 214-311. Dec 2943. $21 \mathrm{pp}$. Prepared by Experimental Towing Tank, Stevens Institute of Technology.

177. The Effect of an Air-Bubble Screen on Pressures Due to Underwater Explosions, by J.J. Donoghue. Aug 1944. $27 \mathrm{pp} ., 12 \mathrm{f1gs.}$

179. Strain and Vibration Measurements on an Intermediate Shaft Strut of DE 49, by R.T. McGoldrick. Jun 1943. $6 \mathrm{pp} ., 5 \mathrm{figs}$.

180. Initial Turning Movements - USS DIXIE (AD14) - Representative of Auxiliaries ADI4 and 15, ASI1 and 12, AR5. Jun 1943. $16 \mathrm{pp}$.

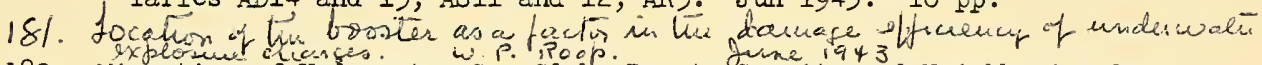

182. Migration of Underwater Gas Globe Due to Gravity and Neighboring Surfaces, by E.H. Kennard. Dec 1943. 33 pp., 17 figs.

187. Alternating Bending Stresses in the Shaft of a 110-Foot Submarine Chaser, by F.B. Bryant. Mar 1944. 7 pp., 8 flgs.

188. Static Tensile Test of a 3000-Pound Lightweight Anchor Type (LWT), Mark II, Assembly l, by J.W. Day. Apr 1944. 12 pp., 7 figs.

189. A Vibration Manual for Fngineers, Dovid Toylor Model Bosin. Report R-189. pp., 34 figs.

A VIBRATION MANUAL FOR ENGINEE.2S (SECOND EDITION), by R.T. McGoldrick. Dec 1957. vi, 27p. graphs, diagrs. (Structural Mechanics Laboratory Research and Development Report) UNCLASSIFIED

195. Tests of Antivibration Devices for This manual contains a collection of formulas useful to design (BB56), by F. Mintz. Mar 1946. engineers in their efforts to minimize trouble from mechanical vibration. The formulas conform with a notation based on the inch-pound-second (ips) system of units unless specifically stated 196. The Reduction of Buoyancy of Vario otherwise.

in Water, by Lt. J.F. Hutchinson, USNR. Dec 1943. 9 pp., 6 figs. 
201. Electronic Methods of Observation at the David W. Taylor Model Basin. Part 8 - A High-Frequency Square-Wave Generator, by It. G. Robert Mezger, USNR. Feb 1944. 14 pp., 7 figs.

202. Progress Report on Underwater Explosion Research - Bureau of Ships Project $\mathrm{E} 139$. Feb 1044.

Part I - A Method for Determining Energy Absorption of Steel at ㅍigh Rates of Loading, by M.A. Greenfielä. pp. 1-10, figs 1-10.

Part 2 - The Pressure-Time Curve for Underwater Explosions of Very Small Charges of Tetryl, by M.M. Shapiro and E.T. Habib. pp. 11-18, figs. 11-15.

Part 3 - The Radial Displacement of Plastically Deformed Diaphragms, by

Dr. G.E. Hudson. pp. 19-23, figs. 16-21.

Part 4 - The Pressure-Time Relationship in Water near the center of a Clamped Circular Steel Diaphragm under Explosive Loading, by J.J. Donoghue. pp. 24-25, fig. 22 .

Part 5 - Resolution of the Peak Pressure Recorded with TourmalineCrystal Pressure Gages, by J.J. Donoghue and R.B. Baxter. pp. 26-31, figs. 23-24.

203. Experiments in the Production and Photography of Intersecting Underwater Shock Waves, by Lt. D.C. Campbell, USNR. Sep 194310 pp., 7 figs.

206. The Suitability of MOIDWOOD for the Manufacture of Ship Propellers, by M. Kirstein and H.R. Thomas. Nov 1943. 11 pp., 6 figs.

207. The Brittle Failure of Medium Steel in Ship Structures, by Capt. W.P. ROop, USN. Oct 1943. 10 pp., 4 figs.

209. (Aero 691). Airflow Study on Two Bridge Arrangements for Minesweeper Vessels, by William Barnett. May 1944. 15 pp., 14 figs.

211. Index of Technical Information. Part 8 - Subject Index of Miscellaneous Technical Information in TMB File QQ/Misc. Oct 1943. $10 \mathrm{pp}$.

212. Resistance-Strain Characteristics of Stretched Fine Wires, by W.J. Sette', I.D. Anderson, and J.G. McGinley. Sep 1945. 28 pp., 13 f'lgs.

213. The Performance of Wire-Resistance Strain Gages As Influenced by the Drying Time of Three Mounting Cements, by Dr. B.L. Miller, L.D. Anderson, and H. Shoub. Jan 1946. 22 pp., 8 figs. 
214. Electronic Methods of Observation at the David W. Taylor Model Basin. Part 9 - A Photoelectric Time-Interval Meter for Instantaneous Velocity Measurements, by Lt. G. Robert Mezger, USNR. Mar 1944. 8 pp., 4 figs.

216. The Effect of Thrust Direction and Position on the Steering of Ships, by Dr. K.E. Schoenherr. Jun 1944. 7 pp., 5 figs.

220. The Procedure in the Preparation of Technical Reports at the David Taylor Model Basin. Dec 1943. 6 pp., 1 fig.

221. Standard Reference Scales for Wind, Weather, sea and Swell. Jan 1944. $5 \mathrm{pp}$., $1 \mathrm{fig}$.

224. A Fairing for Reducing the Feather and Wake Produced by a Submarine Periscope at the Water Surface, by G. Grimminger. Jun 1944. 28 pp., 18 figs.

225. Instructions for Typing and Layout of Reports and Translations. Feb 1944. $27 \mathrm{pp}$., 14 figs.

226. Method of Mechanical Impedance and the Electrical Analogy, by R.T. McGoldrick. Sep 1947. 21 pp., 5 figs.

240. Dynemic and Static Compression Testing of 3/8-Inch Copper Balls, by D.E. Abkowitz. Jul 1947. 22 pp., 10 figs.

241. Tests to Determine the Flooding Rate of the Tail Cone of the 325-Pound Mark 17 Depth Bomb, by M. Kirstein. Oct 1944. 10 pp., $10 \mathrm{figs.}$

243. A Brief Study of the Plastic Behavior of Steel in Way of the Tensile Fractures in a Group of Plate Specimens, by Capt. W.P. Roop, USN. Jul 1944. 27 pp., 14 figs.

244. Progress Report on Underwater Explosion Research - Bureau of Ships Symbol E139. Apr 1944.

Part 6 - Notes on the Shock in Ships Due to an Underwater Explosion, by Dr. E.H. Kennard. pp. 1-3.

Part 7 - A Family of Surfaces of Revolution Representine Shapes of Deformed Circular Dlaphregms, by Dr. G.E. Hudson. pp. 4-1l, figs. $1-5$. 


\section{R- SERIES}

Part 8 - The Effect of Temperature Changes on Calibration of Piezoelectric Gages, by Dr. A. Borden. pp. 12-13.

Part 9 - The Termination of Transmission Lines Used with Piezoelectric Gages, by J.J. Donoghue and R.B. Baxter. pp. 14-18, figs. 6-7.

245. The Calculated Pressure Distribution about the Mark 19 Torpedo, by Dr. M.A. Garstens. Jan 1945. 5 pp., 2 fizs.

246. Experimental Determination of the Suitability of Crystal Accelerometers for Shock Measurements, by W.F. Curtis and H.I. Rich. May 1944. 6 pp.; 1 fi்.

247. Index of Technical Information. Part 6 - Numerical Index of Translations. Niay 1944. 25 pp. Superseded by Report 1160.

248. Procress Report on Underwater Explosion Research - Bureau of Ships Symbol II3G. May 1944.

Part 10 - A Method for Determining the Energy Absorption of Thin Steel Diaphragins under Jydrostatic Pressure, by M.A. Greenfield. pp. 1-10, figs. 1-7.

Part 11 - Errors Encountered in Calibrating Piezoelectric Gages with Slow-Recording Instruments, by Dr. A. Borden. pp. 11-21, figs. 8-17.

Part 12 - Damage to a Vertical Diaphragm As a Function of Depth, by C.T. Johnson. pp. 22-26, figs. 18-20.

Part 13 - Time-Displacenent Studies of Diaphragms Deformed by ExnIosive Loading, by Dr. G.E. Hudson. pp. 27-41, figs. 21-35.

Part 14 - Plastic Deformation of and Absorption of Energy by Thin CircuIar Plates under Normal Loading, by Dr. A.N. Gleyzal. pp. 42-56, figs. $36-46$.

249. Welding Test 207 - Tensile Strength of Butt Welds in Special-Treatment Steel Plate, by J.W. Day. Nov 1947. 12 pp., 3 figs.

251. Catamaran Float Arrangement for Towing the Outboard Projector of a Model NK2 Portable Supersonic Depth Recorder - Instructions for Assembling and Towing, by P. Eisenberg. Jun 1944. 8 pp., 7 figs. 
252. A Study of the Surface Effects Caused by an Underwater Explosion. Part 1 - 1750 Pounds of Torpex near the Bottom in 40 Feet of Water, by Capt. H.I. Saunders, USN, and It. D.C. Campbell, USNR. Jul 1944. $16 \mathrm{pp} ., 14$ figs.

254. Progress Report on Underwater Explosion Research - Bureau of Ships Symbol E139. Jun 1944.

Part 15 - Effect of Dielectric Absorption in a Cable upon the PressureTime Record of an Underwater Explosion, by M.M. Shapiro and E.T. Habib. pp 1-5, figs. 1-2.

Part 16 - Additional Data on the Pressure-Time Curve for Underwater Explosions of Very Small Charges of Tetryl, by M.M. Shapiro and E.T. Habib. pp. 6-7, figs. 3-4.

Part 17-- Resistance-Strain Characteristics of Stretched Fine Wires, by W.J. Sette. pp. 8-10.

Part 18 - A Theory of the Impulsive Plastic Motion of a Thin Diaphragm Normal to Its Initial Plane, by Dr. G.E. Hudson. pp. 11-30, figs. 5-10.

255. Model Tests and Analysis of a Cylindrical Foundation for a 5-Inch 38-Caliber Gun, by E. Wenk, Jr. Feb 1948. 71 pp., 19 figs.

259. Tactical Curves for Frigates PF3 Class - PF3 to 94 and PF99 to 102. Jun 1944. $22 \mathrm{pp}$.

260. Schlieren and High Speed Photography. A Bibliography, Compiled by R.G. Hill and F.A. Raven. Jun 1944. 16 pp.

265. Progress Report on Underwater Explosion Research - Bureau of Ships Symbol E139. Jul 1944.

Part 19 - Notes on the Conditions of Brittle Rupture of Ship Plates of Medium Steel, by Capt. W.P. Roop, USN. pp. 1-16, figs. 1-5.

Part 20 - Calculation of the Principal Strains of Small, Thin Diaphragms Dynamically Loaded, by B. Stiller and A.R. Cohen. pp. 17-29, figs. $6-15$.

267. Experimental and. Theoretical Investigations of the Mass-Plug Accelerometer, by D.M. Smith. Mar 1946. 20 pp., 14 figs.

269. Calibration of Piezoelectric Gages at the David Taylor Model Basin, by Dr. A. Borden. Nov 1944. 20 pp., 13 figs. 


\section{R- SERIES}

271. Additional Notes on the Conditions of Fracture of Niedium Steel Ship Plates, by Dr. D.F. Nidenburg and Ccpt. W.P. Roop, USN. Jur 1945. $19 \mathrm{pp} ., 7$ figs.

274. Reslstance Tests of Two Small Torpedo Forms, by W.H. Bowers. AuE 1945. 5 pp., 4 figs.

276. Notes on the Conditions of Brittle Rupture of Ship Plates of Medium Steel, by Capt. W.P. Roop, USN. Jul 1944. 17 pp., 5 figs.

277. A Time-Saving Method of Compiling, Tabulating, and Indexing Iarge Groups of Data, by M.C. Roemer. Sep 1944. 11 pp., 9 figs.

279. Progress Report on Underwater Explosion Research - Bureau of Ships SymboI E139. Dec 1944.

Part 21 - Vibration of Elastically Clamped Beams, by R. Specht, pp. 1-11, figs. 1-3.

Part 22 - The Effect of a Contact or Near-Contact Explosion on a Freely Suspended Plane Target, by C.T. Johnson. pp. 12-16, figs. $4-7$.

Part 23 - Notes on Plastic Deformation of Elliptical Plates under Hydrostatic Pressure, by M. Levenson. pp. 17-19.

280. Plastic Deformation and Energy Absorption of a Thin Rectangular Plate under Hydrostatic Pressure, by Dr. A.N. Gleyzal. Jan 1945. 18 pp., 3 figs.

282. Comparative Test of the NDRC Tourmaline and the TMB Diaphragm Air-Blast Gages, by B. Sussholz. Aug 1946. 33 pp., 19 figs.

284. (Aero 692). Wind-Tunnel Tests of Parachutes, by R.H. Helmholz. Jan 1949. $22 \mathrm{pp}, 11$ figs.

287. (Aero 694). Airflow Tests over Flight Deck of 1/48-Scale Model CVL48 with Vurious Leading Edges, by J. Norman Fresh. Jan 1945. 14 pp., 10 f1gs.

289. Model Tiests of Weld Reinforcements for the Hatch Corners of Welded Ships, by Comdr. G.I. Smith, USN (Ret). Nov 1944. 29 pp., 24 figs. 


\section{R- SERIES}

292. (Aero 696). Wind-Tunnel Test of Multiple Frequency Antenna, AN/UP $\dot{A}-2$. May 1950. $11 \mathrm{pp} ., 10$ figs.

293. (Aero 697). Iift and Drag Coefficients for Various Types of Radar Antenna Screens. Feb 1951. 8 pp., 5 figs.

294. Investigation of Hull Vibration of USCGC PONTCHARTRAIN (WPG7O), by R.B. Allnutt. Aug 1946. 9 pp., 6 figs.

295. Measurements of Strain in the Radial Webs of the Base Rings of the Mark-37 Gun Director, by E. Wenk, Jr. Jan 1946. 14 pp., 4 figs.

296. Progress Report on Underwater Explosion Research - Bureau of Ships System E139. Apr 1945.

Part 24 - Analysis of the Explosion Damage from Two Small Charges Fired against the Hull of a Liberty Ship, by Dr. G.E. Hudson and Dr. M.A. Greenfield. pp. 1-15, f'lgs. 1-15.

Part 25 - Energy Absorption of Steel Plates of Different Thicknesses under Dynamic or Static Loading, by A.R. Cohen, Chief Specialist (X), USNR, and B. Stiller, Speclalist (X) I/c, USNR. pp. 16-23, figs. $17-22$.

Part 26 - The Resistance of Thick Fused-Quartz and Plastic Plates to Static and Underwater Explosion Pressures, by J.J. Donoghue, C.T. Johnsom, and R.G. Hill. pp. 24-38, figs. 23-25.

298. Measurements of Strains in the Cylindrical Gun Foundations of the USS SARSFIEID (DD837), by E. Wenk, Jr. Sep 1946. 14 pp., 8 figs.

299. (Aero 698). Aerodynamic Forces and Moments for AN/UPA-4 Antenna and Pedestal at Several Wind Speeds. Dec 1948. 27 pp., 23 figs.

302. (Aero 699). Wind Tunnel Tests on Stabilizing Shields of Signal and Eoming Lights for Alrcraft Carriers, by J. Norman Fresh. May 1945. 17 pp., 10 figs.

303. Free-Fall Test of a Model of the Gate of an ARDI2-Class Floating Drydock, by M. Gertler. Aug 1946. 23 pp., 14 flgs. 
304. A Study of the Surface Effects Caused by an Underwater Explosion. Part 2 - 1750-Pound Charges of Torpex near the Bottom and 40 Feet below the Surface, in 96 Feet of Water, by It. D.C. Campbell, USNR. May 1945. $17 \mathrm{pp} ., 12$ figs.

305. Experiments in Photographic Measurement of Velocity and Acceleration with the Type P Airplane Catapult, by It. D.C. Campbell, USNR. Jul 1945. 9 pp., 9 figs.

310. Model Tests to Determine the Forces on the Stern-Gate Operating Mechanism of the ARDI2 Class of Floating Drydocks in Waves, by M. Gertler. Feb 1947. 27 pp., 20 figs.

313. A Photographic Method of Printing Templates on Wood, by F.B. Kaye. Jul 1946. $6 \mathrm{pp} ., 3$ figs.

316. Model Basin Towing Tests to Study the Strength of Radomes, by $M$. Kirstein and S. Cohen. Dec 1946. 8 pp., 7 figs.

317. Hydrodynamic Forces on an Anchor Cable, by I. Landweber. Nov 1947. $13 \mathrm{pp} ., 6$ figs.

318. Photographic Methods of Observation at the David Taylor Model Basin. Part 1 - A Simple Spark Timer for the Eastman High-Speed Camera, Type III, by Lt. Comdr. D.C. Campbell, USNR. Jun 1946. 9 pp., 11 figs.

320. Photographic Methods of Observation at the David Taylor Model Basin. Part 3 - A Comparison of Two Photographic Flash Iamps Used in Photographing Objects Moving at Very High Speeds, by F.B. Kaye. Feb 1947. $15 \mathrm{pp} ., 14 \mathrm{figs}$.

322. (Aero 738). Wind-Tunnel Tests of the Mark 19 Antenna Mount with the Mark 28 and Mark 34 Radar Antennas, by A.W. Sherwood. Feb 1947. 17pp., 15 figs.

328. (Aero 729). Vibration and Drag Tests on the AN-148-A Radar Antenna, by H.B. George and Lt. R.C. Barningham, USNR. Sep 1946. 10 pp., 8 figs.

331. (Aero 717). Wind-Tunnel Tests of Radar Reflectors $\mathrm{MX}-137 / \mathrm{A}$ and $\mathrm{MX}-138 / \mathrm{A}$, by M.J. Bamber. Mar 1946. 11 pp., 8 figs. 
332. (Aero 714). Wind-Tunnel Tests to Determine Alr Loads on Multiple-Ship Moorings for Destroyers of the DD692 Class, by Lt. (jg) M.E. Long, USNR. Dec 1945. 21 pp., 16 figs.

334. Information for Companies Desiring Ship Model Tests. Jan 1946. $3 \mathrm{pp}$. Superseded by Report 652 .

335. A Summary of Information on the Application of Hydrofoils to HighSpeed Surface Craft, by J.H. Curry. Sep 1948. 41 pp., 25 figs.

338. Performance of Controllable-Pitch Propellers on Trials of the USS DAHIGREN (DD187), by C.R. Olson. Aug 1048. $20 \mathrm{pp} \cdot, 15$ figs. Distributed only upon authorization of Bureau of Ships.

340. Development and Performance of a Catamaran-Float Arrangement for Towing a Portable Fathometer, by P. Eisenberg. Oct 1947. 23 pp., 21 figs.

343. (Aero 726). Specification for Drawing and Data Required for Use in Construction of Wind Tunnel Models for Test in the Atmospheric Wind Tunnels at the David Taylor Model Basin. Jul 1946. $6 \mathrm{pp}$.

344. (Aero 708). Wind-Tunnel Tests of 1/12-Scale Model of Towing Dynamometer No. 5. Apr 195I. $10 \mathrm{pp}, 6$ figs.

345. A Twenty-Iens Eigh-Speed Motion-Picture Camere Developed at the Divid Taylor Model Basin, by Lt. (jg) N.T. Partch, USNR, and C.W. Wyckoff. Jun I, 48.37 po., 24 figs.

347. Tensile Tests of Small-Scale Welded Joints, by T.D. Tuft. Mar 1948. $20 \mathrm{pp}$., 8 figs.

348. Underwater Explosion Tests of Simple Structures Fabricated with Everdur Brazing, by T.D. Tuft. Dec 1947. 29 pp., 20 figs.

350. Constructive Suggestions and Inventions by Personnel in the Naval Establishment, a Reprint of AINAV 227 dated 8 May 1946. Sep 1946. 5 pp.

351. Operating and Service Manual for the TMB Type LA Strain Indicator, by W.S. Campbell. Jul 1947. 32 pp., 19 figs.

353. (Aero 744). Cavitation Test of 1/20-Scale Model of the F4U-I Airplane with External Stores, by A.W. Sherwood, C.E. Lauritsen, and T.G. Reed. Aug 1947. $18 \mathrm{pp} ., 9$ figs.

355. (Aero 714). Wind-Tunnel Tests of Multiple Ship Moorings. Part 2 EC2 Class Liberty Ships, M.E. Long. Jan 1949. 20 pp., 16 figs. 


\section{R- SERIES}

356. Instructions for Preparing Correspondence for Duplication by the Ditto and DuplimaT Processes. May 1947. 6 pp., 2 figs.

359. Investigation of Lamp Feilures on Earth-Moving Equipment, by E.0. Berdahl. Dec 1947. 27 pp., 18 figs.

360. Investigation of Methods of Sweeping Y-Type Acoustic Mines, by R.T. McGoldrick. Dec 1947. 26 pp., 19 figs.

364. Water-Tunnel Cavitation Tests on a System of Tandem Sound Domes, by H. Eggers. May 1948. 8 pp., 10 figs.

365. The Dairy of an Inspection Trip to Europe in October-December 1045, by Capt. H.E. Saunders. Jul 1947. 193 pp., 69 figs.

366. Model Basin Tests of Floats for Astern Fueling, by P. Eisenberg. Oct 1947. 16 pp., 11 figs.

367. Photographic Measurement of Velocity and Acceleration of the Type $P$ Airplane Catapult Launching Dead Loads of 6800 and 9300 Pounds, by B.F. Von Bernewitz. Sep 1947. 7 pp., 8 figs.

375. (Aero 722). Wind-Tunnel Tests of a Full-Scale Model Underwater Sound Signal (Preliminary Data), by W. Barnett and R.T. Patterson. Aug 1951. 22 pp., 11 figs. 


\section{UNCLASSIFIED C - REPORTS}

C-3. Vibration Measurements Made II July 1947 on the USS ODAX (SS484), Research Project SRD265 (C-172-34), by Samuel Davidson. Aug 1947. 9 pp., 2 figs.

C-6. Vibration Measurements Made on the USS PHILIPPINE SEA (CV47) during Standardization and Miscellaneous Trials of 5 June to I July 1947, Research Project SRD265 (C-172-33), by V.S. Hardy. Aug 1947. 9 pp., 4 flgs.

C-7. A Presentation of the Problem of Rudder-Travel Rates, by S.C. Gover and G.R. Hagen. Aug 1947. 7 pp., 1 flg.

C-8. (Aero 737). Wind-Tunnel Tests of Underwater Sonar Domes. Part I Pressure Distribution and Alr Flow Studies of 1/2-Scale Models of 60-Inch and 120-Inch Chord Domes of TMB Section Profiles, by J.F. Huggins and J.E. Blalock. Sep 1947. 30 pp., 21 figs.

FOR OFFICIAL USE ONLY.

C-11. (Aero 725).

C-12. (Aero 725).

C-13. Research on the Development and Propagation of Hydrodynamic Noise. Progress Report 1 - The Development of Facilities and Photographic Methods for the Study of Turbulence in Water, by P. Elsenberg, M.S. Macovsky, and C.E. Lemich. Sep 1947. 19 pp., 9 flgs. FOR OFTICIAL USE ONLY.

C-19. Propellers for the Mark 25 Torpedo, TMB Research E202, by J.G. Hill. Sep 1947. 23 pp., 15 figs.

C-26. Characterization of Torpedo Exploder Impellers, Project GIRDIR, by H.A. Eggers. Oct 1947. 14 pp., 9 figs.

C-29. Description of Instruments Employed in the Operational Tests of the Gun-Elevating Systems of the CAl39 Class P1lot Turret, by L. Mason Deland. Oct 1947. 9 pp., 2 figs.

C-30. Performance of Concussion Valves in Vent1lation Ducts, by Drewry Smith. Nor 1947. 15 pp., 8 figs.

C-31. (Aero 725). 
C-32. (Aero 725).

C-34. Vibration Measurements Made 18 August 1947 on the USS AMBERJACK (SS522), by Samuel Davidson. Nov 1947. 13 pp., 5 flgs.

C-36. (NS. 712-059). Structural Vibration Problems of Ships - A Study of the DD692 Class of Destroyers, by Norman H. Jasper. Feb 1950. $117 \mathrm{pp} ., 61$ figs.

C-37. Measurements of Streins and Deflections of a 1/10-Scale Model of the 8-Inch Gun Turrets for Cruisers of the CA68 Class, by L. Mason DeIand. Unpublished.

C-38. Description of Test of Hydraulic Training Buffer of CAl39-Class Pllot Turret, by I. Meson DeIand and Joseph F. Rhodes. Feb 1948. 30 pp., 23 flgs.

C-41. Static Tests of a 1/5-Scale Model of the Mark 1 Mod 1 Breechblock and Housing for the 8-Inch Mark 16 Gun, by Charles A. Wagley. oct 1949. $13 \mathrm{pp} ., 6 \mathrm{flgs}$.

C-43. The Performance of Watertight Doors under Explosive Loading, by Drewry Smith. Nov 1949. $55 \mathrm{pp} ., 31 \mathrm{figs}$.

C-50. Gun-Blast Tests of Watertight Doors in a S1mulated Deck House, by Drewry Smith. Jan 1948. $4 \mathrm{pp}, 1 \mathrm{fig}$.

C-64. (Aero 749). Wind-Tunnel Tests to Determine Aerodynamic Forces and Moments on ShIps Heeled in Beam Winds. Part I - DD692 Class Destroyers, by M.E. Long and C.I. Benedum. Dec 1947. 21 pp., 13 I1gs.

C-75. Two Floats Proposed by the David Taylor Model Basin for a Naval Ordnance Laboratory Acoust1c Transducer, by Leo F. Fehlner and Leonard Pode. Feb 1948. $12 \mathrm{pp}$. $1 \mathrm{flg}$.

C-77. The Hydrodynamic Characteristics of the NRL ShIp-Towed Sonar Projector Housing, by Leo F. Fehiner. Apr 1948. 8 pp., 2 figs.

C-79. Structural Tests and Analysis of Models of Rig1d Knees for FlightDeck Bents of the USS ESSEX (CV9), by Francis F. Vane. Jul 1949. $85 \mathrm{pp} ., 55$ flgs. 
C-80. Vibration Studies of Ship Hulls by Means of Vibration Generators, by Virg1l s. Hardy. Nov 1949. 32 pp., 11 figs.

C-82. Natural Frequencles Measured on the CAl39-Class Pilot Turret, by Samuel Davidson. Dec 1948. 13 pp., 8 flgs.

C-84. (Aero 751).

C-106. (Aero 751).

C-125. Rudder Des1gn Data for Hunter-K1ller Sh1p (CIK 1) Obtained from Tests on Flve Model Rudders, by Grant R. Hagen. Jun 1948. 14 pp., 6 figs .

C-128. Wind-Tunnel Tests of a 1/2-Scale Model of the Type AR-60-SF2 Sonar Dome to Determine Forces and Moments in Yaw, by J.B. H1ppler and M.S. Macovsky. Jun 1948. 11 pp., 5 11gs. FOR OFFICIAL USE ONLY.

C-130. (Aero 757). Wind-Tunnel Tests to Determine Air Loads on Moored Floating Drydocks. Part I - The ARD-12 and AFD-1 in Varlous Configurations, by James E. Blalock and Frank A. Nickols. Jul 1948. 28 pp., 14 figs.

C-135. Resistance of the Mark 13-2 Torpedo with Suspension Bands - Project TMB E228, by J.G. H1ll. Jul 1948. 11 pp., 7 figs.

C-146. Model Tests and Prediction of Full-Scale Forces and Moments on the Retractable NRL 120-Inch Sonar Dome, by Phlllip Elsenberg, Morris S. Macorsky, and Walter L. Stracke. Apr 1949. 28 pp., 17 f1gs. FOR OFFICIAL USE ONLY.

C-149. Vibration and Nolse Tests of Timken Trunnion Roller Bearings on ISM297, by Virg1l S. Hardy and Norman H. Jasper. Dec 1048. 9 pp., 8 figs .

C-158. The Influence of Metacentric Stability on the Dynamic Longitudinal Stability of a Submerine, by E.D. Hoyt and F.H. Imlay. Oct 1948.20 pp., 5 figs.

C-163. (NS 731-002). The Measurement of Performance of the Gun-Elevating System of the 8-Inch 55-Callber P1lot Turret, by W1lliam D. Hunter. Feb 1951. 33 pp., 11 figs.

C-164. (NS 731-002). The Measurement of Performance of the Training System of the 8-Inch 55-Caliber P1lot Turret, by Vicent J. Mildenberg. May 1950. 28 pp., 7 flgs. 
C-165. (NS 731-002). Experimental Analysis of the Recoll System of the 8-Inch 55-Caliber Guns Mark 20, Mod 1, by E.T. Hab1b. Mar 1950. 70 pp., 36 figs.

C-166. (NS 731-002). The Elastic Behavior of the Rotating Structure of the CAl39-Class Pilot Turret under Static Loading, by Edward Wenk, Jr. and Charles A. Wagley. Mar 1950. 52 pp., 25 figs.

C-170. Vibration Measurements Made 11 August 1948 on the USS ODAX (SS484), by Norman H. Jasper. Jan 1949. 10 pp., 5 f1gs.

C-174. The Measurement and Control of Keel-Block Loads During Drydocklng Tests of the USS CEARIES R. WARE (DD865), by Edward Wenk, Jr. Aug 1949. 28 pp., 7 figs.

C-188. (NS 712-045). The Effective Horsepower of the Type 4 (Radar) Periscope Reduced Head Section, by A. Hoyt. Dec 1948. 6 pp., 2 Pigs.

C-199. (Aero 725).

C-217. (NE 051-237). The Flow of Large Air Bubbles About a 54-Inch Sonar Dome, by M.L. Lasky and W.I. Stracke. July 1951. 18 pp., 8 Iigs. FOR OFFICIAL USE ONLY.

C-231. (NS 731-002). The Elastic Behavior of the CA139-Class P1lot Turret with Gunfire Loading, by L.M. DeLand. Oct 1950. 33pp., 27 flgs.

C-235. (Aero 757). Wind-Tunnel Tests to Determine Air Loads on Moored Floating Drydocks. Part 2 - I/245-Scale Model AFDB4-Class Floating Drydock in Various Conflgurations, by Frank A. Nickols and James M. Lee. Jul. $1949.21 \mathrm{pp} ., 11 \mathrm{flgs.}$

C-245. (Aero 773).

C-253. Model Rudder Torque Tests, DD927 Class, by S.H. Brooks. Aug 1949. $6 \mathrm{pp}, 3 \mathrm{figs}$.

C-268. (NS 712-067). Vibration Survey of the USS CORAI SEA (CVB43) Conducted during Ship Trials, by Ralph B. Allnutt. Oct 1949. 26 pp., Q. Iligs.

C-280. (Aero 776).

c-282. (Aero 782).

$$
\begin{aligned}
& \text { C-297 Resistance experments on a systemalec peries } \\
& \text { of strean -lined bodies of ruolutwon. apr } 1950 \\
& \text { NTIS no. ATI-86478 }
\end{aligned}
$$


UNCIASSIFIED C - REPORTS

C-301. (NS 715-007). Report on Rudder Torque Obtained from Tests of ExPT8 Motor Torpedo Boat, by J.E. Curry. Apr 1950. 39 pp., 22 figs.

C-310. The Effect of Bottom Form of a Sonar Dome on Cavitation and Separation, by S.H. Brooks. Mar 1950. 24 pp., 15 flgs. FOR OFFICIAL USE ONLY.

C-330. (NS 712-079). An Aluminum Tripod Mast - Its Structural Characteristics and Response under Static and Dynamic Load, by Norman H. Jasper. Nov 1950. 74 pp., 21 f1g8.

C-335. Study of the Dynamic Stability of the Mark 13 Torpedo in Pitch and Yaw, by Joseph E. Joers. Dec 1950. 19 pp., 7 figs. Revised edition October 195l. 19 pp., 7 figs.

C-339. (NS 713-049). Acoustic Measurements in an Echoic Tank, by H.M. Fitzpatrick and T.E. Conway. Aug 1950. 21 pp., 10 IIgs.

C-355. (Aего 758).

C-356. (NS 715-090). Activated Antirolling Tanke Tested on the USS PEREGRINE (E-AM373), by Francis F. Vane. Jun 1951. 169 pp., 58 flgs.

C-399. (Aero 799).

C-412. (Aero 799).

C-413. (Aero 799).

C-415. (NS 731-037). Structural Test of DMS23 PO_e Mast and Rigging during Depth-Charge Firing, by Horman H. Jasper. Jun 1951. 19 pp., 6 I1ge.

C-452. (NS 712-068). Hydrodynamic Induced Vibrations of Cylinders Towed in Various Combinations, by Dr. A. Borden, D.B. Young, and W.M. Ellsworth, Jr. Sep 1951. 12 pp., 5 figs.

C-454. The Development of a Buoy for Meterological Set AN/SMI-1 ( ) and the Ground Tackle for Anchoring, by Roland A. Ebner. Dec 1951. 20 pp., 4 figs.

C-462. (NS 632-004). A Photoelastic Investigation of the Streases in a Controllable-Pltch Propeller Hub, by Joseph S. Brock. Sep 1952. $19 \mathrm{pp.,} 6 \mathrm{flgs}$. 
UNCIASSIFIED C - REFORIS

C-479. (NS 715-102). Approximate Theory of Heaving and Pitching of Hydrofolls in Regular Shallow Waves, by Dr. Georg P. Weinblum. Oct 1954. 38 pp., 4 figs.

C-487. (NS 715-086). Effects of Varlations in Thickness/Chord Ratio of Rudders in a Slipstream, by G.R. Hagen. Jan 1952. 9 pp., 3 figs.

C-490. Deformation of the Rubber Bottom of a 60-Inch Sonar Dome Due to Hydrodynamic Pressures, by Morris S. Macovsky and William M. Ellsworth, Jr. Feb 1952. 16 pp., 8 flgs. FOR OFFICIAL USE ONLY.

C-498. (NR 252-001). Studies to Develop a H1gh-Speed Landing Craft Having the Same Proportions as the World War II ICVP, by J.H. Curry. May 1952. 26 pp., 11 figs.

C-527. (Aero Data Report 1). Wind-Tunnel Tests of the 0.30- and 0.38-Scale Model Roll-Stabilization Fins, by George C. Newcome, Jr. Feb 1953. 18 pp., 10 flgs.

C-548. (NE 051-012). Test for Fallure of $\mathrm{CW}-177 \mathrm{~A} / \mathrm{U}$ and AN/SQG-4 Type Sonar Domes with Hydraulic Loading, by M.S. Macovsky, W.L. Haberman and M. Dean. May 1953. 43 pp., 32 figs. FOR OFFICIAI USE ONLY

C-555. (NS 731-037). On the Structural Design of the Midship Section, by M. St.Den1s. Oct 1954. 111 pp., 37 f1gs. FOR OFFICIAL USE ONLY.

C-566. Section Characteristics of the AT-350/BRC Submarine Whip Antenna, by

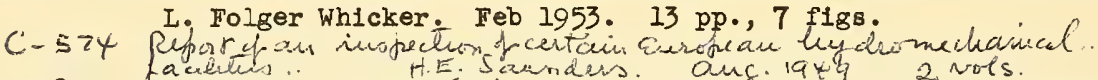
C-580. (NR 255-002, NE 020-632). Television Identification of a sunten Submarine, by F.B. Temple. Jul 1953. 11 pp., 3 figs.

C-582. Tactical Trials of NRP PONTA DEIGADA (EX USS ADJUTANT, AMS60). by W.G. Surber, Jr. Aug 1953. 12 pp., 5 flgs.

C-583. SGT. TRUMAN 0. OLSON (YMP-2) Equipped with Voith-Schnelder Cyclodial Propellers. Standardization Trial Analysis and Model Resistance Test Results, by George K. Brown. Jul 1953. 22 pp., 4 figs.

C-658. (Aero 869). Bow-Wave-Detachment Distance for Spheres at Low Supersonic Mach Numbers, by William C. Volz. Aug 1954. 21 pp., 8 figs. 


\section{TRANSIATIONS}

1. Calculation of the Pressure Distribution on Airship Hulls [Berechnung der Druckverte1lung über Luftsch1ffkörper], by Prof. Dr.-Ing. Theodore von Karman. Abhandlungen aus dem Aerodynamischen Institut an der Technischen Hochschule, Aachen, 1927. Translated by D.F. Windenburg. Mar 1930. 11 pp., 3 figs.

2. Strength of Ships [Festigke1t der Schiffe], by Felix Pietzker. Ernst Slegfried Mitgler and Son, Berlin, 1914. Unpublished. Partial Draft in TMB File.

3. New Experiences and Developments in the Technique of ShIp Trials [Neue Betriebserfahrungen und Entwicklungen der Schiffbau-Versuchstechnik], by Dr. Günther Kempr. Werft-Reedere1-Hafen, Vol. 11, No. 21, 1 Nov 1930, pp. 437-442. Translated by M.C. Roemer. Dec 1930. 18 pp.

4. Introduction to the Theory of Elast1c1ty [E1nfuhrüng in de Elastiz1tätstheorle], by August Föppl. Excerpts from Vorlesungen über techn1sche Mechan1k, Vol. 3, B.G. Teubner, Le1pz1g and Berlin, 1923. Translated by W.P. Roop. Apr 1931. 114 pp., 27 figs.

5. The Critical External Pressure of Cylindrical Tubes [Der kritische Aussendruck zylindrischer Rohre], by $R$. von Mises. VDI-Ze1tschrift, Vol. 58, No. 19, May 1914 , p. 75. Translated and annotated by D.F. Windenburg. Aug 1931. 17 pp., 8 f1gs.

6. The Critical External Pressure of Cylindrical Tubes under Uniform Radial and Axial Load [Der kritische Aussendruck für allse1ts belastete zylindr1sche Rohre], by R. von Mises, Stodolas Festschr1ft, Zur1ch, 1929, pp. 418-430. Translated and annotated by D.F. WIndenburg. Aug 1931. 19 pp., 8 figs.

7. The Calculation and Measurement of Elast1c Natural Frequencies of Sh1p Hulls [Über Rechnung und Messung der elastischen E1genschwingungen von Schiffskörpern], by Dr.-Ing. E. Schadlofsky. Jahrbuch der Schiffbautechnischen Gesellschaft, Vol. 33, 1932, pp. 280-335. Translated by R.T. McGoldrick and M.C. Roemer. Jun 1934. 55 pp., 29 flgs. Also Supplement to Translation 7. Nov 1935. 15 pp., 4 flgs.

8. On the stability of stiffened Plates [Über die stab1lität verstelfter Platten], by Prof. S. TImoshenko. Der E1senbau, Vol. 12, 1921, pp. 147163. Translated and annotated by M.C. Roemer and D.F. Windenburg. Jul 1935. 23 pp., 6 flgs.

9. Cavitation Tests with Systematically Varied Model Propellers [Kav1tationsversuche mlt systemat1sch veränderten Propellermodellen], by Hermann Lerbs, Hamburg Model Basin. Werft-Reederel-Hafen, Vol. 13, No. 17, 1 Sep 1932, pp. 253-255. Translated by M.C. Roemer. Feb 1936. 4 pp., 4 figs. 


\section{TRANSLATIONS}

10. On the Setting-up of Cavitation [Zur Frage des Kavitationseintritts], by Hermann Lerbs. 80th Communication of the Hamburg Model Basin. WerftReedere1-Hafen, Vol. 12, No. 13, 1 Jul 1931, pp. 243-244. Translated by M.C. Roemer. Feb 1936. 11 pp., 4 flgs.

11. The Loading of a Ship in a Seaway [Die Beanspruchung des Schiffes im Seegang], by George Schnadel. Jahrbuch der Schiffbautechnischen Gesellschaft, Vol. 37, 1936, pp. 129-152. Translated by M.C. Roemer. Jan 1936. 28 pp., 21 flgs.

12. Vibration Neutralizer for Ships [Neutralizzatore di vibrazioni per nav1], by Ing. Ugo Loser. Ricerche di Ingegnerla, Vol. 12, No. 1, Jan-Feb 1934, pp. 28-35. Translated by R.T. McGoldr1ck. Jan 1936. 12 pp., 15 flgs.

13. Recording High Frequency Vibrations by the Scratch Process [Aufze1chnen schneller Schwingungen nach dem Ritzverfahren], by Wilhelm Pabst. VDIZe1tschrift, Vol. 73 , No. 46, Nov 1929, pp. 1629-1633. Translated by M.C. Roemer. Feb 1936. 14 pp., 14 flgs.

14. The Cavitation Tank of the Hamburgische Schiffbau-Versuchsanstalt [Der Kav1tat1onstank der Hamburgischen Schiffbau-Versuchsanstalt], by Hermann Lerbs. 83rd Communication of the Hamburg Model Basin. WerftReedere1-Hafen, Vol. 12, No. 11, 1 Jun 1931, pp. 191-194. Trenslated by M.C. Roemer. Feb 1936. 13 pp., 6 flgs.

15. The Betz-Prandtl Vortex Theory of the Screw Propeller As Adapted to the Technical Method of Calculation [D1e Betz-Prandtlsche W1rbeltheorle der Treibschraube und ihre Ausgestaltung zum technischen Berechnungsverfahren], by H.B. Helmbold. Werft-Reedere1-Hafen, Vol. 7, 1926, pp. 565-569, 588-595. Translated by M.C. Roemer. Feb 1936. 35 pp., 13 figs.

16. Welding in Shipbuilding [Schwe1ssen im Schiffbau], by Hermann Lottmann. Sch1ffbau, Sch1ffahrt und Hafenbau, Vol. 33, Nos. 13, 14, 15, and 16, 1932, pp. 3-31 (reprint). Unpublished. Rough Draft in TMB translation file.

17. The Problem of Strength in Any Direction in Shipbuilding [Das Raumfestigke1tsproblem Im Sch1ffbau], by Dr.-Ing. Gustav Wrobbel. Jahrbuch der Sch1ffbautechnischen Geselischaft, Vol. 28, 1927, pp. 447-492. Unpublished. Rough Draft in TMB translation file.

18. Studies of Propeller Sections with Reduced Susceptibility to Cavitation [Untersuchungen über Propellerproflle mit herabgesetzter KavitationsEmpfindlichkeit], by $\mathrm{H}$. Holl. Technlsche Mechanik und Thermodynamik, Forschung auf dein Geblete des Ingenleurwesens, Vol. 3, No. 3, May-Jun 1932. Translated by M.C. Roemer. Feb 1936. 20 pp., 22 flgs.

19. Analysis of Propeller Tests [Auswertung von Schraubenversuchen], by Prof. Dr.-Ing. H. Horn. Schiffbau, Schiffahrt und Hafenbau, Vol. 36, No. 18, 15 Sep 1935 (reprint). Translated by M.C. Roemer. Feb 1936. 33 pp., 7 figs. 


\section{TRANSLATIONS}

20. Experimental and Theoretical Investigation of Cavitation in Water [Experimentelle und theoretische Untersuchungen iber Hohlraumbildung (Kav1tation) Im Wasser], by $J$. Ackeret. Technische Mechanik und Thermodynamik, Vol. 1, No. 1, Jan 1930, pp. 1-22, 63-72. Translated by M.C. Roemer. Feb 1936. 85 pp., 39 figs.

21. Tests of Sections under Cavitation [Profilmessungen be1 Kavitat1on], by ot to Walchner. Hydromechanische Probleme des Schiffsantriebs, Hamburg, 1932, pp. 256-267. Translated by M.C. Roemer. Feb 1936. 19 pp., 8 f1gs.

22. Cavitation [Kavitation - Hohlraumb1ldung], by $J$.Ackeret. Handbuch der Experimentalphys1k, Vol. 4, Part 1, pp. 463-486. Translated by M.C. Roemer. Jun 1933. $22 \mathrm{pp} ., 30 \mathrm{f1gs.}$

23. Results of Measurements on Propeller Sections [Ergebnisse von Messungen an Propellerprofilen], by G. Flügel. Technische Hochschule, Danzig, pp. 315-321. Hydrodynam1sche Probleme des Schiffsantriebs, Hamburg Congress 1932. Translated by R.C. Darnell. Jun 1933. 6 pp., 6 figs.

24. Cavitation Limits According to Series Tests [Kavitationsgrenzen nach Serienversuchen], by Hermann Lerbs. Werft-Reedere1-Hafen, Vol. 16, No. 22, 15 Nov 1935, pp. 338-340. Translated by M.C. Roemer. Jun 1936. 7 pp., 3 figs.

25. Principles of Testing open Water Propellers in the H.S.V.A. Water Tunnel [D1e Grurdlagen der Messung fre1fahrender Schrauben im Kavitationstank der Hamburg1schen Schiffbau-Versuchsanstalt], by Hermann Lerbs. WerftReedere1-Hafen, Vol. 14, No. 12, 15 Jun 1933, pp. 169-172. Translated by M.C. Roemer. Jun 1936. 26 pp., 10 flgs.

26. High Seas Test Trip - Oscillation and Acceleration Measurements [Hochseemessfahrt. Schwingungs- und Beschleunigungsmessungen], by H. Horn. Jahrbuch der Schiffbautechnischen Geselischaft, Vol. 37, 1936, pp. 153213. Translated by M.C. Roemer. Jun 1936. 69 pp., 57 figs.

27. Experimental Investigation of Airfoll Sections in Grid Arrangement [Experimentelle Untersuchung eines Tragflügelprof1ls be1 Gitteranordnung], by $K$. Christian1. Report of Aerodynamic Laboratory of Kaiser W1Ihelin. Institute. Luftfahrtforschung, Vol. 2, No. 4, 27 Aug 1928, pp. 1-110. Translated by M.C. Roemer. Jun 1936. 73 pp., 37 figs.

28. The Stress Distribution in the Flanges of Thin-Walled Box Girders [D1e Spannungsvertellung in den Flanschen dünnwandiger Kastenträger], by $\mathrm{Dr}$. Ing. George Schnadel, Jahrbuch der Sch1ffbautechnischen Geselischaft, Vol. 27, 1926, pp. 206-291. Translated and annotated by D.F. Windenburg and E.O. Ebel. Jun 1936. 83 pp., 27 f'lgs.

29. Recent Experimental Contributions to the Buckling Problem [Neuere exper1mentelle Belträge zur Frage der Knlckfestigke1t], by K. Memmler. Proceedings of the Second International Congress for Applied Mechanics, Zur1ch, 12-17 Sep 1926, pp. 357-363. Unpubl1shed. Rough Draft in TMB translation file. 


\section{TRANSLATIONS}

30. Theory and Design of Compression Members [Theorle und Berechnung der e1sernen Brucken], by Dr.-Ing. Frledrich Ble1ch. Jul1us Springer, Berlin, 1924. Translated by M.C. Roemer. Annotated by D.F. Windenburg and J.M. Frankland. Jan 1942. 111, 50 pp., 32 f1gs.

31. The Buckling of Stiffened Plates in Shear [Das Auskn1cken verste1fter Bleche unter Schubbeanspruchung], by C. Schmleden, Ze1tschrift für Flugtechnik und Motorluftsch1ffahrt, Vol. 21, No. 3, 1930, pp. 61-65. Translated by M.C. Roemer. Jun 1936. 12 pp., 4 flgs.

32. On the Buckling of Plates [Über die Knlckung von Platten], by Dr.-Ing. George Schnadel. Jahrbuch der Schlffbautechnischen Gesellschaft, Vol. 30, 1929, pp. 170-194. Translated by M.C. Roemer. Feb 1938. 18 pp., 9 figs.

33. On Stab1l1ty Problems in Thin Cylindrical Shells [über Stab1litatsprobleme dünner Kre1szylindrischer Schalen], by $K$. von Sanden and $F$. Tolke. Ingenleur-Arch1v, Vol. 3, 1932, pp. 24-66. Translated by F.A. Raven and annotated by D.F. Windenburg. Dec 1949.66 pp., 15 figs.

34. The Economic Propulsion of Sh1ps [WIrtschaftlicher Sch1ffsantrieb], by Dr.-Ing. Günther Kempf. VDI-Ze1tschr1ft, Vol. 71, No. 30, 23 JuI 1927 , pp. 1049-1052. Jun 1936. 13 pp., 7 f1gs.

35. Local Control of Wake [Örtl1che Nachstromregelung], by Dr.-Ing. Günther Kempf. Werft-Reedere1-Hafen, Vol. 1, No. 24, 1920, pp. 550-554. Translated by F.A. Raven, Revised Edition, Dec 1948. 11 pp., 6 figs.

36. Notes on the Theory of Propellers. Calculation of Torques and Thrust, Determination of Local Pressures, Predicting Cavitation [Note sur la théorle des hél1ces. Calcul des couples et des poussées], by Roger Brard. Bulletin de l'Assoclation Technlque Marltıme et Aéronautique, No. 36, 1932, pp. 713-748. Translated by M.C. Roemer. Jun 1936. 13 pp.

37. Scale Effect in Model Propeller Experiments [Kennwerteinflüsse be1 Schiffsschrauben Modellversuchen], by Fritz Gutsche. Jahrbuch der Schiffbautechnischen Gesellschaft, Vol. 37, 1936, pp. 277-279. Translated by M.C. Roemer. Jun 1936. 23 pp., 13 flgs.

38. The Strength of Cylindrical Shells, Stiffened by Frames and Bulkheads, under Uniform External Pressure on All Sides [Uber das Festigkeitsproblem Guerstelfter Hohlzylinder unter Allseitig Glelchmassigem Aussendruck], by K. von Sanden, Kiel and K. Gunther, Danzig. Werft and Reedere1, Vol. I (1920), No. 8, pp. 163-168, No. ?, pp. 180-108, No. 10, pp. 216-221; Vol. 2 (1921), No. 17, pp. 505-510. Translated by Dr. E.N. Labouvie and annotated by Dr. E. Wenk, Jr. and Dr. W.A. Nash, Mar 1952. 86 pp., 34 figs.

39. Reduction of Disturbing Vibration of Shaft Bearings for a Constant ExcitIng Frequency [Die Beruhigung storend Schwingender Welienlager bei konstanter Erregerfrequenz], by Erich Hahnkamm. Annalen der Physik, Vol. 14, 1932, pp. 683-698. Translated by R.T. McGoldrick. Oct 1936. 15 pp., 10 figs. 
40. Reduction of Foundation Vibration for a Varlable Exc1ting Frequency [D1e Dämpfung von Fundamentschwingungen be1 veränderlicher Erregerfrequenz], by Erich Hahnkamm. Ingenleur-Arch1v, Vol. 4, 1933, pp. 192-201. Translated by R.T. McGoldrick. Oct 1936. 15 pp., 10 flgs.

41. Anomalles in the Propagation of Sound Waves of High Amplitude [Anomalle nella propagazione di onde acust1che di grande amplezza], by E.F. Gh1ron. Excerpt from Alta Frequenza, Vol. 4, No. 5, 1935, pp. 3-54. Unpubl1shed. Rough draft, (lacking equations) in TMB translation file.

42. Invest1gations of Ships in Steering Maneuvers [Untersuchungen an Schiffen be1 Rudermanövern], by Dr.-Ing. K. F1scher. Werft-Reedere1-Hafen, Vol. 17 , Nos. $7,8,9,10$, and 11,1 Apr to 1 Jun 1936, pp. 81-86, $102-$ 106, 116-119, 159-161, 166-169. Translated by M.C. Roemer. Dec 1936. 43 pp., $24 \mathrm{figs}$.

43. On Photomechanical Printing (D1azotype) [Iets over Lichtdrukken; Diazotyple], by $P$. Cohen Henriquez. Chemlsch Weekblad, Vol. 33, No. 16, Apr 1936, pp. 242-246. Translated by M.C. Roemer. Unpublished.

Rough draft in TMB translation file.

44. On the Act1ve Stabil1zation of Ships - "Scheinlot" Stab1lization [über die akt1ve stabilisierung von Schiffen], by Carl yon den stelnen. Sch1ffbau, Schiffahrt und Hafenbau. Vol. 36, No. 17, 3 sep 1935 (reprint). Translated by M.C. Roemer. Feb 1937. 9 pp., 4 figs.

45. Elastic1ty, Theory and Research [Elast1z1tätstheorle und Versuch], by Prof. Dr.-Ing. George Schnadel. Jahrbuch der Schiffbautechn1schen Gesellschaft, Vol. 32, 1931, pp. 153-181. Unpubl1shed. Rough draft, (lacking equations, tables, and illustrations) in TMB translation file.

46. Study of Cavitation on Screw Propellers [Untersuchung der Kavitation an Schraubenpropellern], by Dr.-Ing. Hermann Lerbs. Report No. 131, Ham= burg1sche Schiffbau-Versuchsanstalt, Hamburg, 1936. Booklet, $92 \mathrm{pp}$. Translated by M.C. Roemer. Apr 1937. 84 pp., 38 f1gs.

47. Restrained Deformation in Welded Jolnts [Behinderte Formänderung in Schwe1ssnähten], by Franz Bollenrath. Stahl und Elson, Vol. 54, No. 24, 1934, pp. 630-634. Unpubl1shed.

48. Advances in the Theory of Flow in Englneering and Shipbuilding [Fortschritte der Strömungslehre im Maschinenbau und Sch1ffbau], by $H$. Fottinger. Jahrbuch der Schiffbautechnischen Gesellschaft, Vol. 25, 1924, pp. 295-344. Trans. by M.C. Roemer. May 1952. 64 pp., 46 figs.

49. In the Field of Explosives - The Now Primers [Nel campo degl1 explosiv1 1 nuov1 Innoscant1], by $F$. Grottanell1. La ChImica $\in$ I'Industr1a, Vol. 18, No. 5, May 1936, pp. 232-235. Translated by M.C. Roomer. Unpub11shed. Rough draft in TMB translation file.

50. The Effective WIdth In Box Girders and in the Double Bottom [DIe mittragende Bre1te in Kastenträgern und im Doppelboden ], by Dr.-Ing. Goorge Schnadel. Werft-Reedere1-Hafen, Vol. 9, No. 5, 7 Mar 1928, pp. 92-101. Translated by M.C. Roemer and annotated by R.D. Conrad and D.F. Windenburg. Jan 1938. 37 pp., $8 \mathrm{flgs.}$ 
51. Theory and Practice of Vibration Testing Machines (Theorie und Praxis der Schwingungsprüfmaschinen], by Dr.-Phil. Wilhelm Späth. Julius Springer, Berlin, 1934, 98 pp. Translated by M.C. Roemer and R.T. McGoldrick. Mar 1938. $94 \mathrm{pp} ., 48 \mathrm{figs}$.

52. Calculation of Rudder Force [Berechnung der Ruderkraft], by Dr.-Ing. K. F1scher. Werft-Reedere1-Hafen, Vol. 19, No. 17, 1 sep 1938, pp. 259261. Translated by M.C. Roemer. Nov 1938. 8 pp., 3 figs.

53. Investigations of Pressure and Flow on a Ship Model [Untersuchungen Uber Druck und Strömungsverlauf an einem Schiffsmodell], by Dr.-Ing. Wilmar Laute. Jahrbuch der Schiffbautechnischen Geselischaft, Vol. 34, 1933, pp. 403-460. Translated by M.C. Roemer and annotated by R.D. Conrad. Mar 1939. 71 pp., 49 figs.

54. Roughness and Scale Effect on Marine Propellers [Rauhigkeits- und Kennzahleinfluss bei Schiffschrauben], by Dr.-Ing. Günther Kempf. WerftReedere1-Hafen, Vol. 19, No. 11, 1 Jin 1938, cp. 145-148. Translated by M.C. Roemer and annotated by R.D. Conrad. Nov 1939. 8 pp., $4 \mathrm{figs}$.

55. On the Theory of Steering Processes in Ships [Zur Theorie des Steuervorganges be1 Schiffen], by $W$. Kucharski. Werft-Reedere1-Hafen, Vol. 13, No. 3, 1 Feb 1932, pp. 35-42. Translated by M.C. Roemer. Nov 1939. 24 pp., 4 figs.

56. Sh1p Resistance in Water of Limited Depth - Resistance of Seagoing Vessels in Shallow Water [Schiffswiderstand auf beschränkter Wassertiefe Widerstand von Seeschiffen auf flachem Wasser], by otto Schlichting. Jahrbuch der Schiffbautechnischen Gesellschaft, Vol. 35, 1934, pp. 127148. Translated by M.C. Roemer. Jan 1940. 26 pp., 17 figs.

57. Wake Measurement with Ship Models [Mitstrommessung an Schiffsmodellen], by C.W. Prohaske ad W.P.A. van Lammeren. Schiffbau, Schiffahrt und Hafenbau, Vol. N5, No. 16, 15 Aug 1937, pp. 257-262. Translated by M.C. Roemer. Aug 1940: 10 pp., 6 flgs.

58. Measurement and Evaluation of Propeller Thrust [Messung und Wertung des Propellerschubes], by Reinhold Schulze. Werft-Reedere1-Hafen, Vol. 14, No. 21,1 Nov 1933, pp. 303-304. Unpublished. Rough draft in TMB translation file.

59. Recent Measurement of Propeller Thrust [Neuere Messungen des Propellerschubes ], by Dr. G. Bauer. Werft-Reedere1-Hafen, Vol. 2, No. 23, 7 Dec 1921, pp. 718-720. Translated by M.C. Roemer. Oct 1942. 4 pp.

60. Experimental Definition of Wake [Définition experimentale du sillage], by E.G. Barrilion. Report of Parls Model Basin. Translated by F.A. Raven. Oct $1942.11 \mathrm{pp} ., 1 \mathrm{fig}$.

61. Correlation of Model Tests and Full-Scale Trials [La Mise en parallèle des essals de modèles et des essals à la mer], by E.G. Barrillon. Bulletin de l'Association Technique Maritime et Áéronautique, No. 29, Session de 1925, pp. 339-388. Also reprint from Bulletin, May 1925, 49 pp. Translated by F.A. Raven. Unpublished. $38 \mathrm{pp}$., $11 \mathrm{figs}$. Reference copy available in TMB Library 
62. Thrust Deduction [Vom Sog], by Dr.-Ing. H.M. We1tbrecht. Sch1ffbau, Schiffahrt und Hafenbau, Vol. 39, No. 11, 1 Jun 1938, p. 180. Translated by M.C. Roemer. Sep 1940. 3 pp.

63. The Central Test Station Aboard the S.S. NJASSA [Zentral-Messzelle NJASSA], by Dr.-Ing. H. Hoppe. Werft-Reedere1-Hafen, Vol. 19, No. 14, $15 \mathrm{JuI}$ 1938, pp. 217-222. Translated by M.C. Roemer. May 1940. 14 pp., 22 figs.

64. Exceeding the Buckling Limit in Thin Plates [D1e Überschreitung der Knlckgrenze bei dünnen Platten], by Prof. Dr.-Ing. George Schnadel. Proceedings of the Third International Congress of Applied Mechanics, Stockholm, 1930, Vol. 3, pp. 73-81. Translated by M.C. Roemer. Dec 1949. $12 \mathrm{pp} ., 5$ figs.

65. Dynamic Stress Measurements [Dynamische Spannungsmessungen], by Dr.-Ing. S. Berg. VDI-Ze1tschr1ft, Vol. 81, No. 10, 6 Mar 1937, pp. 295-298. Translated by M.C. Roemer. Jan 1942. 8 pp., 13 flgs.

66. Buckling of Sh1ps 1 Plates [Knickung von Schiffsplatten], by Prof. Dr.Ing. George Schnadel. Werft-Reedere1-Hafen, Vol. 11, No. 22, 5 Nov 1930, pp. 467-465. Trans lated by M.C. Roemer. Sep 1950. 26 pn., 12 figs.

67. Results of a Serles of Tests with a Wholly and Partlally Roughened Ship Model [Ergebn1sse aus elner Versuchsre1he, ausgerührt mit elnem ganz und teilwe1se rauh gemachten Schiffsmodelij, by Dr.-Ing. W.P.A. van Lameren. Reprint from Schiffbau, Schiffahrt und Hafenbau, Vol. 39, No. 11, 1938. Translated by M.C. Roemer. Jan 1942. 9 pp.

68. Analysis of Propulsion Components in Relation to Scale Effect by Means of Model Tests [Zerlegung der Antrlebskomponenten in Abhänglgke1t vom Maszstabseinfluss mit H1lfe von Schiffsmodellversuchen], by Dr.-Ing. W.P.A. van Lammeren. Werft-Reedere1-Hafen, Vol. 19, No. 17, 1 Sep 1938, pp. 261-265. Translated by M.C. Roemer. Sep 1950. 14 pp., 12 figs.

69. Hull Form of Minimum Res1stance [Forme de carène de molndre résistance], by V. Yourkevitch, Naval Architect. Bulletin de l'Association Technique Marltime et Aéronaut1que, No. 36, 1932, pp. 687-711. Unpubl1shed. Rough draft in TMB translation file.

70. Measurements and Investigations of Marine Propellers [Messungen und Untersuchungen an Schiffsschrauben], by Dr. G. Bauer. Jahrbuch der Schiffbautechnischen Gesellschaft, 1923, pp. 236-268. Unpublished. No copy available.

71. Studies of Cavitation and Corrosion in Turbines, Centrifugal Pumps, and Propellers [Untersuchungen über Kav1tation und Korrosion be1 Turbinen, Turbopumpen, und Propellern], by H. Föttinger. From Hydraulische Probleme, pp. 14-64, VDI, Berlin, 1926. Unpublished.

72. Analysis of Several Wake Tests with a Sh1p Model [Analyse einiger Mitstrommessungen an einem Schiffsmodell], by Dr.-Ing. W.P.A. van Lammeren. Reprint from Schiffbau, Schiffahrt und Hafenbau, Vol. 39, No. 19, 1 Oct 1938, pp. 343-350. Translated by M.C. Roemer. Jun 1942. 15 pp., 12 figs. 
73. On the Treatment of Stab111ty Problems by Means of the Energy Method [Über die Behandlung von stab1l1tätsproblemen mit H1]fe der energet1schen Methode], by K. Marguerre. Ze1tschr1ft für angewandte Mathematik und Mechanik, Vol. 18, No. 1, 1 Feb 1938, pp. 57-73. Unpublished.

74. Theory of Notch Stresses: Principles for Exact Stress Calculation [Kerbspannungslehre, Grundlagen für genaue Spannungsrechnung], by H. Neuber, Jullus Springer, Berlin, 1937, pp. 1-160. Translated by F.A. Raven and annotated by J.S. Brock. NOv 1945. 180 pp., 106 flgs. FOR OFFICIAI. USE ONLY.

75. Resistance and Stability Tests with Three Trawler Models [W1derstandsund Stabilitätsversuche mit drel Fischdampfermodellen], by W. Graff and E. Heckscher. Werft-Reederei-Hafen, Vol. 22, No. 8, 15 Apr 1941, pp. 115-120. Translated by F.A. Raven. Jun 1942. 15 pp., 8 f1gs.

76. On the Load Capacity of a Longitudinally stressed Plate Panel after the Buckling Load Has Been Exceeded [Über die Tragfähigke1t elnes längsbelasteten Plattenstrelfens nach Uberschreiten der Beullast], by $K$. Marguerre and $E$. Trefftz. Zeitschrift für angewandte Mathematik und Mechanik, Vol. 17, No. 2, Apr 1937, pp. 85-100. Unpubl1shed. Copy in T.M translation file.

77. Pract1cal Methods of Solving Equat1ons [Prakt1sche Verfahren der Gle1chungsauflösung], by $R$. von Mises and H. Pollaczek-Gelringer, Ze1tschr1ft für angewandte Mathemat1k und Mechanik, Vol. 9, No. 1, Feb 1929, pp. 58-77, and No. 2, Apr 1929, pp. 152-164. Unpubl1shed: Rough draft in TMR translation file.

78. Buckling Stresses of Rectangular Plates with Long1tudinal stiffeners under Un1form Compress1on [Beulspannungen von Rechteckplatten m1t Längsste1ffen be1 gle1chmässiger Druckbeanspruchung], by D1pl.-Ing. Rudolf Barbré. Der Baulngenleur, Vol. 17, No. 25/26, 26 Jun 1936, pp. 268-273. Translated by M.C. Roemer. Jul 1943. 16 pp., 7 figs.

79. The General stab1l1ty Problem of a Compressed Plate St1ffened w1th Angles at Its Edges [Das allgemeine Stab1litätsproblem der gedrückten, durch Randwinkel verstärkten Platte], by $\mathbf{E}$. Chwalla. Ingenleur-Arch1v, Vol. $5,1934, \mathrm{pp} .54-65$. Unpubl1shed. Copy in TMB translation file.

80. Additional Notes Concerning the Construction and Arrangement of the New Dutch Model Basin [We1tere Mittellungen über Bau und E1nrichtung des neuen holländ1schen Versuchstanks]. Werft-Reedere1-Hafen, Vol. 13, No. 12 , 15 Jun 1932, pp. 178-180. Unpublished. No copy avallable.

81. The Establishment of a Modern Naval Experimental Station [Utber die E1nrichtungen elner modernen Sch1ffbautechn1schen Versuchsanstalt], by Dr.-Ing. Frledr1ch Gebers, V1enna. De Ingenleur, No. 13, 31 Mar 1928, p. 107. Unpubl1shed. Copy in TMB translation file.

82. Remodeling F1ghting Sh1ps [Der Umbau von Krlegsschiffen], by H. Evers. Werft-Reedere1-Hafen, Vol. 15, No. 6, 15 Mar 1934, p. 75. Unpublished. Copy in TMB translation file. 
83. New Viewpoints in the Design of Ship Rudders [Neuere Gesichtspunkte für den Entwurf von Schiffsrudern], by Dr.-Ing. W. Kucharsiki. Jahrbuch der Schiffbautechnischen Gesellschaft, Vol. 32, 1931, pp. 206-257. Unpublished. Rough draft in TMB translation file.

84. On Ship Resistance in Shallow water [über Schiffswiderstand auf beschränkter Wassert1efe], by Dr.-Ing. H.M. We1tbrecht. Jahrbuch der Sch1ffbautechnischen Geselischaft, Vol. 21, 1920, pp. 122-160. Unpublished. Rough draft in TMB translation file.

85. The Distribution of the Displacement Flow around the Hull of a Ship [Die Vertellung der Verdrängungsströmung neben der Schiffswand], by Hermann Lerbs. Werft-Reedere1-Hafen, Vol. 9, No. 13, 7 JuI 1928, pp. 263-266. Translated by R.C. Darnell. Nov 1943. 10 pp., 4 figs.

86. Some Contemporary Problems of Aerodynamics [Quelques problèmes actuels de l'aérodynamique], by Theodore von Kármán. Journées Techniques Internationales de I'Aér'onautique, $28 \mathrm{Nov}$ and $2 \mathrm{Dec}$ 1932. Chambre Syndicale des Industries Aéronautiques, Paris. Translated by M.C. Roemer. Jan 1944. 22 pp., 15 figs.

87. The Naval Experimental Station at Lichtenrade [Die Marineversuchsanstalt in Iichtenrade], by otto Schlichting. VDI-Zeitschrift, Vol. 67, No. 16, 21 Apr 1923, pp. 385-389. Unpublished. Rough draft in TMB translation file.

88. Motor Torpedo Boats - Schnellboote [Motortorpedoboote - Schneliboote], by D1pl.-Ing. W1lhelm Hadeler. VDI-2e1tschrift, Vol. 83, No. 32, 12 Aug 1939, pp. 917-924. Translated by M.C. Roemer. Jan 1940. 18 pp., 15 figs.

89. New Cavitation Research [Neue Kavitationsversuche], by Dr. Hermann Lerbs. Werft-Reedere1-Hafen, Vol. 20, No. 16, 15 Aug 1939, pp. 258-260. Translated by L. Rubinowitz. Jan 1940. 4 pp., 2 figs.

90. The Development of Ship Model Testing Since 1900 [D1e Entw1cklung des Schiffbauversuchswesens se1t der Jahrhundertwende unter besonderer Berücks1cht1gung der deutschen Inst1tute], by Dr.-Ing. Günther Kempr. Werft-Reedere1-Hafen, Vol. 20, No. 15, 1 Aug 1939, pp. 235-239. Translated by M.C. Roemer. May 1940. 12 pp., 2 figs.

91. Results of Full-Scale Propeller Tests on S.S. TANNENBERG [Ergebnisse Naturgrosser Schraubenversuche auf Dampfer "Tannenberg" $]$, by Dr.-Ing. Günther Kempf. Werft-Reedere1-Hafen, Vol. 20, No. 12, 15 Jun 1939, pp. 167-174. Translated by M.C. Roemer. Jul 1941. $18 \mathrm{pp}$., 18 figs.

92. Recent Tests of the Tensile Strength of Ship Members [Neue Versuche über Zugfest1gke1t von Sch1ffsverbänden], by Prof. Dr.-Ing. George Schnadel. Werft-Reedere1-Hafen, Vol. 20, No. 16, 15 Aug 1939, pp. 256-258. Translated by M.C. Roemer. Dec 1947. 7 pp., 4 figs.

93. Effect of Welding Conditions on the Warping of Girders with off-Center Welds [EInfluss der Schweissbedingungen auf die Trägerkrümmung be1 aussermittiger Schwe1ssung], by Dr.-Ing. R. Malisius. Elektroschweissung, Vol. 11, No. 8, 1940, pp. 131-134. Translated by M.C. Roemer. Jul 1941. 12 pp., 9 figs. 


\section{TRANSLATIONS}

94. The Entropy Diagrams of Internal Combustion Engines Including Gas Turblues [Die Entrople-Diagramme der Verbrennungsmotoren einschliesslich der Gasturbine], by Dipl.-Ing. P. Ostertag. Julius Springer, Berlin, 1928. Translated by W.J. Quentin, Bureau of Yards and Docks. Oct 1941. 11, 73 pp., 16 figs.

95. Sealed Contact Joints in Stationary Machine Parts [Berührungsdichtungen an ruhenden Maschinenteilen], by Karl Trutnovsky. VDI-Ze1tschrift, Vol. 84, No. 17, 27 Apr 1940, pp. 277-282. Translated by Marion Saunders and M.C. Roemer. Nov 1941. 14 pp., 27 flgs.

96. A New Torsiograph Sultable for High RPM's [Ein neuer für hohe Drehzahlen geelgneter Torsiograph], by Dr.-Ing. J. Geiger. Werft-Reedere1-Hafen, Vol. 21 , No. 10, 15 May 1940, pp. 132-135. Translated by F.A. Raven. Dec 1941. 8 pp., 14 figs.

97. Contribution to strength Testing on Sh1ps Underway [Beitrag zur Festigkeitsmessung am fahrenden Schiff], by Dr. W. Dahlmann and Ing. K. Remmers. Sch1ffbau, Schiffahrt und Hafenbau, Vol. 41, No. 1, 1 Jan 1940 , pp. 6-12. Translated by M.C. Roemer. Jan 1942. 12 pp., 9 figs.

98. Varlable Pressure Water Tunnel - Netherlands Model Testing Basin [De Cavitatietank. Excerpt from "Inrichting en Bedrilf van het Neederlandsch Scheepsbouwkundig Proefstat1on"], by Dr.-Ing. J.G. Kon1ng, Report 47 of the Netherlands Model Basin, Marineblad, Jun 1941. Translated by F.A. Raven. Dec 1941. 5 pp., $1 \mathrm{flg}$.

99. The Effect1veness of Fillers in Double Walls against Penetration of AlrBorne Sound [Dle W1rksamke1t von Füllstoffen in Doppelwänden gegen den Durchgang von Luftschall], by A. Jacobsen. Der Baulngenleur, Vol. 20 , No. $47 / 48,5 \mathrm{Dec} 7939$. pp. 572-576. Translated by M.C. Roemer. Jun 1942. $10 \mathrm{pp}$., $8 \mathrm{flgs.}$

100. Prediction of the Movements of Large Ships in Launching [Vorausbestimmung der Bewegungsvorgänge belm Stapellauf grosser Sch1ffe], by Henry Stemmer. Schiffbau, Schiffahrt und Hafenbau, Vol. 41, No. 17, 1 Sep 1940, pp. 229-234. Translated by F.A. Raven. May 1942. 12 pp., 7 flgs.

101. Lightweight Steel Design of Machine Tools [Stahlleichtbau bei Werkzeugmaschinen], by Dr. -Ing. C. Krug. VDI-Zeitschrift, Vol. 84, No. 1, 6 Jan 1940, pp. 11-16. Translated by M.C. Roemer. Jul 1942. 13 pp., $20 \mathrm{flgs}$.

102. The Determination of Pressure in Atmospher1c Shock Waves Due to Blasting and the Firing of Guns [Untersuchungen zur Bestimmung des Druckes in den beim Sprengen und Schiessen entstehenden Luftstosswellen], by W11helm Schnelder. Zeitschrift für das gesamte Schless- und Sprengstoffwesen, Aug to Dec 1939, pp. 230-331. Translated by F.A. Raven. Apr 1943. v, $32 \mathrm{pp} ., 20$ f1gs.

103. Elastic Stresses in a Plane System with a Reinforced Opening [Sollecitazioni elastiche di un sistema piano con foro rinforzato], by L. Sobzero. Rome Memorie della Ciasse di Sclenze Fislche, Matematiche e Naturali, Vol. 10, No. 4, 1939, pp. 105-141. Translatec by F.A. Raver. Annotated by J.S. Brock. Sep 1951. $36 \mathrm{pp} ., 20 \mathrm{figs}$. 
TRANSLATIONS

104. The Effect of Rest Periods on the Time and Fatigue Strengths of Metallic Materials [Der Einfluss von Betriebspausen auf die Ze1t- und Dauerfestigkeit metallischer Werkstoffe], by Franz Bollenrath and H. Cornelius. VDI-Zeitschrift, Vol. 84, No. 18, 4 May 1940, pp. 295-299. Translated by F.A. Raven. Oct 1942. vi, 14 pp., 19 figs.

105. Launching of the Battleship SCHARNHORST [Ablauf des Schlachtschiffes SCHARNHORST], by F. Riecke. VDI-Ze1tschrift, Vol. 81, No. 13, 27 Mar 1937, p. 372. Translated by F.A. Raven. Oct 1942. 3 pp., 2 figs.

106. Stopping and Reversing of Marine Engines [Abstoppen und Umsteuern von Schiffsmaschinenanlagen], by Dr.-Ing. F. Schmidt. Werft-Reedere1Hafen, Vol. 21, No. 18, 15 Sep 1940, pp. 231-235. Translated by F.A. Raven. Unpublished. $15 \mathrm{pp} ., 8 \mathrm{flgs}$. Reference copy available in TMB Library.

107. Recent Results In Spark Cinematography [Neuere Ergebnisse der Funkenkinematographie]; by Dr.-Ing. Hubert Schardin and W. Struth. Ze1tschrift für technische Physik, Vol. 18, No. 11, Nov 1937. Translated by F.A. Raven. Dec 1942. 10 pp., 17 figs.

108. On the size of Gas Bubbles and Droplets in Liquids [Über die Grösse von Gasblasen und Flüssigke1tströpfchen in Flüssigkeiten], by Siegfried Halberstadt and Paul H. Prausnitz. Ze1tschrift für angewandte Chemle, Vol. 43, 1930. Translated by F.A. Raven. Mar 1943. i, 19 pp., 8 figs.

109. Natural Vibration and Damping of Gas Bubbles in Liquids [E1genschwingung und Dämpfung von Gasblasen in Flüss1gke1ten], cy Erwin Meyer and Konrad Tamm. Akustische Zeitschrift, Vol. 4, No. 3, May 1939. Translated by F.A. Raven. Apr 1043. 12 pp., 8 flgs.

110. The S1ze of Gas Bubbles in Liquids [Dle Grösse von Gasblasen in Flüssigkeiten], by Robert Schnurmann. Zeitschrift für physikalische Chemie, Vol. 143, Nos. 5 and 6 , Sep 1929, pp. 456-474. Translated by F.A. Raven. Mar 1943. 18 pp., 2 figs.

111. On the S1ze of Gas Bubbles in Liquids [über die Grösse von Gasblasen in Flüsigke1ten], by Robert Schnurmann. Kollo1d-2e1tschrift, Vol. 80, No. 2, Aug 1937. Translated by F.A. Raven. Apr 1943. 6 pp., 3 figs.

112. On Disperse Gases [Über Disperse Gase], by Rudolph Auerbach. Kollo1dZeitschrift, Vol. 77, No. 2, Nov 1936. Translated by F.A. Raven. Unpublished. $10 \mathrm{pp}$, $14 \mathrm{figs.} \mathrm{Reference} \mathrm{copy} \mathrm{available} \mathrm{in} \mathrm{TMB} \mathrm{Library.}$

113. Disperse Gases, I: Thermodynamics and Product1on [Disperse Gase I: Thermodynamik und Herstellung], by Rudolph Auerbach. Forschungs-Institut der AEG, Kollold-Ze1tschrift, Vol. 74, No. 2, Feb 1936, pp. 129-138. Translated by F.A. Raven. Unpublished. 15 pp., 19 figs.

Reference copy available in TMB Library.

114. D1sperse Gases, II: General Properties of Gas Dispersions [Disperse Gase II: Allgemeine Elgenschaften von Gasdispersionen], by Rudolph Auerbach. Kollo1d-Zeltschrift, Vol. 80, No. 1, Jul 1937, pp. 27-31. Trans= lated by F.A. Raven. Unpublished. $8 \mathrm{pp}$. Reference copy available in TMB Library. 
115. Disperse Gases, III: Bubble Size and Time of Rise [Disperse Gase III: Blasengrösse und Aufstiegze1t], by W. Luchsinger. Kollold-Ze1tschrift, Vol. 81, No. 2, Nov 1937, pp. 180-182. Translated by F.A. Raven. Unpublished. 5 pp., 2 figs. Reference copy available in TMB Library.

116. Pressure Distribution on Gable and Hip-Roofs [Druckverteilung an Giebelund Walmdächern], by Prof. Dr.-Ing. H. Müller. Der Bauingenieur, Vol. 20, No. 25/26, 30 Jun 1939, pp. 343-347. Translated by B.A. Wiener. Nov 1939. $10 \mathrm{pp}$., 10 figs.

117. Concerning an Instrument for Determining the Pressure and the Direction of Velocity in a Fluid [Sur un appareil permettant de déterminer le module et la direction de la vitesse dans un fluide], by J. Kampe de Fériet, A. Martinot-Lagarde, and G. Rollin. Excerpt from Comptes Rendus des Séances de l'Académie des Sciences, Meeting of Nov 1938. Translated by M.C. Roemer. Jan 1943. $4 \mathrm{pp}$.

118. Experimental Determination of the Hydrodynamic Increase in Mass in Oscillating Bodies [Die experimentelle Bestimmung des hydrodynamischen Massenzuwachses bel Schwingkörpern], by Rolf Brähmig. Schiffbau, Schiffahrt und Hafenbau, Vol. 41, No. 11, 1 Jun 1940, pp. 159-163, and No. 12, 15 Jun 1940, p. 173. Translated by F.A. Raven. Nov 1943. 22 pp., 8 ilgs.

119. Canceled.

120. Recent Applications of the P1ezo-Electric Measuring Methods in Ballistics Neuere Anwendungen des piezoelectrischen Messverfahrens in der Ballistik], by H. Illgen. Zeltschrlft für technische Physik, Vol. 18, No. 11, Nov 1937. Translated by F.A. Raven. Oct 1943. 6 pp., 6 figs.

121. Mult1ple-Spark Photography of Explosive Phenomena by Toepler's Shimmer Method [Mehrfachfunkenaufnahmen von Explosionsvorgängen nach der Toeplerschen Schlierenmethode], by Dr.-Ing. Werner Lindner. Forschungsarbeiten auf dem Gebiete des Ingenleurwesens, Bulletin 326, Berlin, $1930,18 \mathrm{pp}$. Translated by F.A. Raven and annotated by J.S. Brock. Unpublished. i, $35 \mathrm{pp}$., 31 flgs. Reference copy available in TMB Library.

122. Factors Affecting the Time and Fatigue Strength of Materials [Einflüsse auf die Zeit- und Dauerfestigke1t der Werkstoffe], by Franz Bollenrath. Luftfahrtforschung, Vol. 17, No. 10, 1940, pp. 320-328. Translated by F.A. Raven. Apr 1944. 19 pp., 24 flgs.

123. The "Singing" of Ships' Propellers [Das Singen von Schiffsschrauben], by Dr.-Ing. Fritz Gutsche. VDI-Ze1tschrift, Vol. 81, No. 27, 3 Jul 1937 , pp. 822-823. Translated by F.A. Raven. Unpublished. 4 pp., 2 figs. Reference copy available in TMB Library.

124. Graphic Integrator and Differentiator for Ship Calculations [Graphischer Integrator und Differentiator für Schiffsberechnungen], by David L. Evans. Werft-Reedere1-Hafen, Vol. 18, No. 21, 1 Nov 1937, pp. 312-314. Translated by M.C. Rcemer. Nov 1942. 6 pp., 8 f'igs.

125. On the Colloldal Physics of Disperse Gases (Zur Kolloidphysik Disperser Gase], by Rudolph Auerbach. Zeitschrift fur technische Physik, Vol. 19, No. 12, 1938. Translated by F.A. Raven. Jul 1943. 3 pp. 
126. Produce Good Translations [Schafft gute Ubersetzungen]! From Die Photograph1sche Industrie, Vo1. 28, No. 12, 19 Mar 1930, p. 334. Translated by F.A. Raven. Unpublished. 4 pp. Reference copy available in TMB Library.

127. Definition of Conditions for Testing Self-Propelled Models [Definitie van de voorwaarden voor het model met elgen voortstuwing]. Report No. 25. Nederlandsch Scheepsbouwkundig Proefstation, Wageningen, 1937. Unpublished. Copy in TMB translation file.

128. Motorship Oranje of the Nederland Line [Motorfahrgastschiff oranje der Stoomvaart M1j. "Nederland"]. Werft-Reedere1-Hafen, Vol. 20, No. 20, 15 oct 1939, pp. 316-323. Translated by M.C. Roemer. Nov 1939. 3 pp.

129. Advances in Anchor Design [Fortschr1tte 1m Ankerbau]. Schiffbau, Schiffahrt und Hafenbau, Vol. 40, No. 15, 1 Aug 1939, pp. 284-286. Translated by M.C. Roemer. Nov 1939. 3 pp., 3 flgs.

130. On the Induced Current and Torque of the Disk of an Alternating Current Meter, 1.e., a Watt-Hour Meter [Über die 1nduzlerte Strömung und das Drehmoment be1 der Sche1be eines Wechselstrommotorzählers], by $w$. Rogowsk1. Archiv für Elektrotechn1k, Vol. 1, No. 5, 1912, pp. 205-232. Translated by F.A. Raven. Unpublished. 56 pp., 7 fig. Reference copy available in TMB Library.

131. Effect of Cavitation on the Output of Ship Propellers [E1nfluss der Kav1 tation auf die Le1stung von Schiffsschrauben], by A. Betz. Proceedings of the Th1rd International Congress for Applied Mechanics, Vol. 1, pp. 411-416. Stockholm, 1930. Translated by F.A. Raven. Unpublished. 9 pp., 9 figs. Reference copy available in TMB Library.

132. Speed of Rise of Air Bubbles in L1quids [Ste1ggeschwindigke1t von Luftblasen in Flússigke1ten], by T. Bryn. Forschung 4, No. 1 , Jan/Feb 1933. Also a digest in VDI-Ze1tschrift, Vol. 77, No. 6, i1 Feb 1933. p. 158. Translated by F.A. Raven. Jun 1949. 9 pp., 6 flgs.

133. Erosion by Cavitation and by the Impact of Drops of Liquid [La Corrosion par cavitation et par choc de gouttes liquides], by P. de Haller. Schwe1zer Archiv für angewandte W1ssenschaft und Technik, Vol. 6, No. 3, Mar 1940. Translated by F.A. Raven. Unpublished. 22 pp., 26 figs. Reference copy available in TMB Library.

134. The Opt1mum Thrust Distribution in Propellers [D1e günstigste Schubverte1lung be1 Propellern], by Dr.-Ing. G. Flügel. Sch1ffbau, Sch1ffahrt und Hafenbau, Vol. 47, No. 8, pp. 108-112, $15 \mathrm{Apr} 1940$, and No. 18, pp. 250-252, 15 Sep 1940. Translated by F.A. Raven. Unpublishcd. 19 pp. , $5 \mathrm{flgs.}$. Reference copy available in TMB Library.

135. Plates under Lateral Impact [Platten unter seltilchem Stoss], by $K$. Karas. Ingenleur-Arch1v, Vol. 10, 1939. Translated by F.A. Raven. Apr 1951. 23 pp., 3 figs. 
136. Production of Ocean Waves to Scale in Model Tests. 59th Report of the Hamburg Model Basin [Die Erzeugung Maszstäbl1cher Meereswellen bel Modellversuchen. 59. Mittellung der Hamburgischen Schiffbau-Versuchsanstalt. G.m.b.H.\}, by Dr.-Ing. Günther Kempf and H. Hoppe. WerftReedere1-Hafen, Vol. 10, No. 10, 22 May 1929, pp. 192-196. Translated by F.A. Raven. Unpublished. $14 \mathrm{pp}, 18 \mathrm{flgs}$. Reference copy available in TMB Library.

137. Cataphores1s of Gas Bubbles [Kataphorese von Gasblasen], by Alfred Klemm. Physikalische Ze1tschrift, Vol. 39, No. 22, 15 Nov 1938, pp. 783-793. Translated by F.A. Raven. Sep 1949. 24 pp., 1 fig.

138. On the New Photolith Method [Über den neuen Filmlichtdruck], by Prof. 0. Mente. Die Photographische Industrie, No. 10, 8 Mar 1926. Translated by F.A. Raven. Unpublished. 15 pp. Reference copy available in TMB Library.

139. On the Propagation of Shock Waves in Liquids and Solids [Über Knallwellenausbre1tung in Flüssigke1ten und festen Körpern], by Oswald von Schmidt. Zeitschr1ft für technische Phys1k, Vol. 19, No. 12, 1938, pp. 554-561. Translated by F.A. Raven. Unpublished. 15 pp., 19 figs. Reference copy available in TMB Library.

140. Applications of Supersonics in Collold Research [Die Anwendungen des Ultraschalls in der Kolloldforschung], by H.A. Wannow. Kollo1d-Ze1tschrift, Vol. 81, No. 1, oct 1937, pp. 105-113. Translated by F.A. Raven. Unpublished. $30 \mathrm{pp}$., $6 \mathrm{flgs.} \mathrm{Reference} \mathrm{copy} \mathrm{avallable} \mathrm{in} \mathrm{TMB} \mathrm{Library.}$

141. On a New Accelerometer and Phenomena of Initial Vibrations in Vibration Meters [Uber einen neuen Beschleunigungsmesser und Einschwingvorgange bei Schwingungsmessern], by G. Gerloff. Forschung auf dem Gebiete des Ingenleurwesens ( $A$ ), Vol. 8, No. 3, May/Jun 1937, pp. 143-152. Translated by F.A. Raven. May 1949. 20 pp., 13 figs.

142. Measurement of Absorpt1on, Veloc1ty and Gas Expulsion in the Supersonic Range [Absorpt1ons-, Geschw1nd1gke1ts-, und Entgesungsmessungen 1m Ultraschallgeb1et], by Chr1st1an Sörensen. Annalen der Phys1k, Serles 5. Vol. 26, No.2, 17 Apr 1936, pp. 121-137. Translated by F.A. Raven. Unpubl1shed. $14 \mathrm{pp}$., $10 \mathrm{flgs}$. Reference copy available in TMB Library.

143. Calculation of the Strength of Ax1ally Symmetrical Boller Heads [Die Fest1gke1tsberechnung achsensymmetr1scher Böden und Deckel], by $F$. Schultz-Grunow. Ingenleur-Arch1v, Vol. 4, 1933, pp. 545-554. Translated by F.A. Raven. Unpublished. $15 \mathrm{pp} ., 14 \mathrm{flgg}$. Reference copy available in TMB Library.

144. Travel in Currents - Excerpts from Johow-Foorster: Manual for Sh1pbu110Ing [Johow-Foerster: Hilfsbuch für den Sch1ffbau], by Dr.-Ing. E. Foerster. 1928. Translated by F.A. Raven. Unpublished. 4 pp., 4 flgs. Reference copy available in TMB Library.

745. Canceled. 
146. Rise of Gas Bubbles in L1quids [Das Aufsteigen von Gasblasen in Flüsigkeiten], by F. Plckert. Forschung auf dem Geblete des Ingenieurwesens (B), Vol. 3, Nov/Dec 1932, pp. 308-309. Translated by F.A. Raven. Unpublished. $4 \mathrm{pp} ., 1 \mathrm{f} 1 \mathrm{~g}$. Reference copy available in TMB Library.

147. On the Dispersion of Supersonic Vibrations in Liquids [über die Dispersion des Ultraschalls in Flüssigkeiten], by A.K. Dutta. Physikalische Zeitschrift, Vol. 39, No. 5, 1 Mar 1938, pp. 186-187. Translated by F.A. Raven. Oct 1949. 5 pp., 1 fig.

148. On the Coefficient of Temperature of Quartz Plates for Longer Waves [Über den Temperaturkoefflzienten von Quartzplatton für längere Wellen], by I. Koga. Elektrische Nachrichten-Technik, Vol. 12, No. 1 , Jan 1935,2 pp. Translated by F.A. Raven. Unpublished. 3 pp. Reference copy available in TMB Library.

149. The General Electric Slow-Motion Camera, an Instrument for Recording Phenomena of Highest Speeds at Rates of 80,000 down to 16 Images/Sec [AEG-Zeitdehner, Das Film-Aufnahmegerät für Schnellste Vorgänge, 80,000 bis 16 Bilder in der Sekunde, Allgemeine ElektricitäisGesellschaft]. Allgemeine Elektricitäts-Gesellschaft TechnischPhysikalische Werkstätten, Sep 1942, 4 pp. Translated by F.A. Raven. Apr 1949. $7 \mathrm{pp} ., 6 \mathrm{flgs}$.

150. Shielding Electrodes to Produce Tough Weld Seams [Ummantellung der Elektroden zwecks Erhaltung einer zähen Schweissnaht]. Digest Elektrotechnische Zeitschrift, Vol. 56, No. 34, 22 Aug 1935, p. 50. (Avtogennoe Delo, 1935, Vol. 2.) Translated by F.A. Raven. Unpublished. $2 \mathrm{pp}$. Reference copy available in TMB Library.

151. Electrographic Oscillograph [Elektrographischer Oszillograph]. A digest in VDI-Ze1tschrift, Vol. 81, No. $31,31 \mathrm{Jul} 1937$, pp. 922923. Translated by F.A. Raven. Unpublished. 3 pp., 2 figs.

Reference copy available in TMB Library.

152. Calculation and Construction of Osc1llograph Loops [Berechnung und Konstruktion von Oszillographenschleifen]. VDI-Zeitschrift, VoI. 81 , No. 28, $10 \mathrm{JuI} 1937, \mathrm{p} .847$. Translated by F.A. Raven. Unpublished. 2 pp., 2 flgs. Reference copy available in TMB Library.

153. On an Instrument to Measure and Record Sea Waves [über ein Gerät zur Messuns und Aufzelchnung des Seeganges], by Wilhelm Pabst.

Zeitschrift füir Flugteclinik und Motorluftschiffahrt, Vol. 24, 1933 , pp. 598-600 and 616-619. Digest by G. Braun. Zentralblatt für Mechan1k, Vo1. 1, No. 9, 1934, p. 385. Translated by F.A. Raven. Unpublished. 1 p. Reference copy available in TMB Library.

154. Time Recording Device for Motion Plcture Plotographing [Kino-Ze1tbildAufnahmeeinrichtung], by Friedrich Beck. Die Kirotechnik, Vol. 12, No. 4, 20 Feb 1930 , pp. 98-99. Translated by F.A. Raven. Unpublished. $1 \mathrm{p} ., 4 \mathrm{flgs}$. Reference copy available in TMB Library.

155. Physiolog1cal Physics - Contribution to the Study of Shell Shock, Memoir by M. Marage, presented by M.R. Bourreols [Physlque Physiologique Contribution a l'étude des commotions de guerre, Note de M. Marage, presentée par M.R. Bourgeo1s]. Comptes-Rendus des Seánces de l'Academie des Sciences de Paris, 1918. Translated by $R$. W1dmer. Unpub11shed. 5 pp., $1 \mathrm{flg}$. Reference copy available in TMB Library. 
TRANSLATIONS

156. Toepler's Schlieren Method. Basic Principles for Its Use and Quantitative Evaluation [Das Toeplersche Schlierenverfahren. Grundlagen fur seine Anwengung und quantitative Auswertung], by Dr.-Ing. Hubert Schardin. Forschungsheft 367. Supplement to "Forschung auf dem Geblete des Ingenieurwesens (B), "Vol. 5, Jul/Aug 1934, pp. 1-35. Translated by F.A. Raven. JuI $1947.83 \mathrm{pp} ., 79 \mathrm{flgs}$.

157. Underwater Explosions [Sprengungen unter Wasser], by C.E. Bichel. Marine-Rundschau, Nos. 7-12, Jul to Dec 1905, pp. 1345-1357. Translated by F.A. Raven. Unpublished. $16 \mathrm{pp}$., 5 figs. Reference copy available in TMB Library.

158. On Thermal Damping in Spherically Symmetric Vibrating Gas Bubbles [Zur thermischen Dämpfung in kugelsymmetrisch schwingenden Gasblasen], by H. Pfrlem. Akustische zeitschrift, Vol. 5, Jul 1940, pp. 202-212. Translated by F.A. Raven. Unpublished. $17 \mathrm{pp}, 4 \mathrm{flgs}$. Reference copy a vailable in TMB Library.

159. Heat Transmission during H1gh-Speed Pressure Changes in Gases [Der Wärmeübergang bel schnellen Druckänderungen in Gasen], by H. Pfrlem. VDI-Ze1tschrift, Vol. 87, No. 17/18, 1 May 1943, p. 268. Translated by $R$. Widmer. Unpublished. $5 \mathrm{pp}$. Nor 1352. $13 \mathrm{pp}, 13$ figs.

160. Behavior of Several Propellers on one Shaft [Wirkung mehrerer Propeller auf elner Welle], by $H$. Schmierschalski. Hamburg Model Basin, Report 185, Werft-Reedere1-Hafen, Vol. 20, No. 17, 1 Sep 1939, pp. 278 and 279. Translated by L. Rubinowitz. Unpublished. Copy in TMB translation file.

151. Measurement of the Brilliance and Duration of Electric Sparks [Messung der Funkenhelligke1t und Funkendauer], by M. Kornetzki, V. Fomin, and R. Steinitz. Ze1tschrift für technische Physik, Vol. 14, No. 7, 1933, pp. 274-280. Translated by F.A. Raven. Nov 1952. 13 pp., 13 figs.

162. A New Micromanometer [E1n neues Mikromanometer], by A. Betz. Ergebnisse der Aerodynamischen Versuchsanstalt Göttingen, Part 4, pp. 12-13. Translated by $\mathrm{R}$. Widmer. Unpubl1shed. 4 pp., 2 flgs. Reference copy available in TMB Library.

163. Memolr on the Buonocore Propeller [Nota sull'Elica Buonocore], Fiat Motors, Inc., Torino. Supplied by United States Naval Forces Northwest African Waters, 24 Jan 1944. Translated by F.A. Raven. Unpublished. 3 pp. Reference copy available in TMB Library.

164. Extensometer Measurement w1th R1ng-Type P1ckup [Dehnungsmessung mit Ringgebern], by A. The1s. VDI-Zeitschrift, Vol. 87, No. $11 / 12,20$ Mar 1943, p. 154. Translated by R. W1dmer. Unpublished. 4 pp., 2 flgs. Reference copy available in TMB Library.

165. Effect of Bombs on Reinforced Concrete and Thickness of Concrete Required for Safety [Bombenwirkung gegen Stahlbeton und notwendige Schutzd1cken], by Dr.-Ing. 0. Speth. VDI-Ze1tschr1ft, Vol. 87, No. 13/14, Apr 1943. Translated by R. Widmer. Unpublished. 5 pp., 7 flgs. Reference copy available in TMB Library. 
166. Dynamic Investigations on Ships [Dynamische Untersuchungen an Schiffen], by Dr. Wilhelm Spath. Werft-Reederei-Hafen, Vol. 11, No. 5, 1930, pp. 92-93. Translated by R.T. McGoldrick and D.F. Windenburg. Unpublished. $5 \mathrm{pp}$. Reference copy available in TMB Library.

167. Electrography, a New Electric Recording Method by Instrument and Its Application [Elektrographie, ein neues elektrotechnisches Aufzeichnungs-Verfahren und selne Anwendungen], by $P$. Selenyi. Elektrotechnische Zeitschrift, Vol. 56, No. 35, 29 Aug 1935, pp. 961-963. Translated by $R$. Widmer. Unpublished. $10 \mathrm{pp}$., $8 \mathrm{flgs}$. Reference copy available in TMB Library.

168. Detonating Blast-Type Explosions [D1e Zündung der Sprengschüsse], by Dr. K. Drekopf and Dr.-Ing. e.h. C. Beyling. Sprengst offe und zündmittel, Julius Springer, Berlin, 1936, Part 2, pp. 150-304. Translated by F.A. Raven. Unpublished. $248 \mathrm{pp} ., 85 \mathrm{flgs}$. Reference copy available in TMB Library.

169. Large-Scale Underwater Explosions [Grössere Explosıonen unter Wasser], by Dr. C. Cranz, in Lehrbuch der Ballistik, innere Ballistik, die Bewegung des Geschosses durch das Rohr und thre Begle1terscheinungen, Jullus Springer, Berlin, 1926, pp. 179-183. Translated by R. Widmer. Unpublished. $7 \mathrm{pp}$. Reference copy available in TMB Library.

170. The Entrainment of Self-Exclted Oscillations and Their Technical Evaluation [Dle Mitnahme Selbsterregter Schwlngungen und ihre technische Verwertung], by F. Kirschstein. Translated by F.A. Raven. Unpublished. $32 \mathrm{pp} ., 19 \mathrm{flgs}$. Reference copy available in TMB Library.

171. Note on the D1splacement of Gas Globes in Water [Note sur le deplacement du front des gaz dans l'eau], by M.J. Ottenhelmer. Mémorlal de l'Art1llerle Franca1se, Vol. 102, 1933. Translated by R. Widmer. Unpublished. 9 pp. Reference copy available in TMB Library.

172. Development, Theory, and Calibration of Angularly Sensitive Pitot Tube for Two-Dimensional Flow (Cylindrical P1tot Tube) [Das Zylinderstaurohr], by Dipl.-Ing. Fritz Gutsche, in Mittellungen der Preussischen Versuchsanstalt für Wasserbau und Schiffbau. Schiffbau, Schiffahrt und Hafenbau, Vol. 32, No. 1, Jan 1931, pp. 13-19. Translated by F.A. Raven. Unpublished. $14 \mathrm{pp}$., $11 \mathrm{figs.} \mathrm{Reference} \mathrm{copy} \mathrm{available} \mathrm{in} \mathrm{TMB} \mathrm{Library.}$

173. On Turbulent Hydraulic Flow in Stralght P1pes at Very Large Reynolds Numbers [Über turbulente Wasserstromungen in geraden Rohren bel sehr grossen Reynoldschen Zahlen], by J. N1kuradse, Vortrage aus dem Geblete der Aerodynamik und verwandter Geblete. Excerpts from lectures given by A. Gilles, L. Hopf, and Theodore von Kárman. Julius Springer, Berlin, 1930, pp. 63-69. Translated by F.A. Raven. Unpublished. 10 pp., 6 flgs. Reference copy avilable in TMB Library.

174. Photoelectric Torslograph [Photoelektrischer Torslograph], by W. Spillmann. Schwelzer-Archiv für angewandte Wissenschaft und Technik, Vol. 8 , No. 8, Aug 1942, pp. 252-255. Translated by F.A. Raven. Unpublished. 12 pp., 9 flgs. Reference copy available in TMB Library. 
175. Electrical Equipment [Den Elektriska Untrustningen], by Karl Tiselius. Report of the Göteborg Model Basin, pp. 65-84. Translated by F.A. Raven. Unpublished. Rough draft in TMB translation file.

176. The Pallograph [Der Pallograph], excerpt from Applied Sclence of Vibration - A Handbook for Engineers, Physicists and Mathematiclans in Research in the Applied Technology of Periodic Phenomena [Technische Schwingungslehre - Ein Handbuch für Ingenleure, Physiker und Mathematiker bel der Untersuchung der in der Technik angewendeten period1schen Vorgänge], by Dipl.-Ing. Dr. Wilhelm Hort, 2nd Ed., Julius Springer, Berlin, 1922, pp. 80-86. Translated by F.A. Raven. Unpublished. 9 pp., 3 flgs. Reference copy a vailable in TMB Library.

177. Cycles of Gas Turbines and Attempts to Actually Produce Them [Kreis prozesse der Gasturbinen und die Versuche zu ihrer Verwirklichung], by Dr.-Ing. Rudolf Fuchs. Jullus Springer, Berlin, 1940. Translated by F.A. Raven. Apr 1945. 11, 95 pp., 59 figs.

178. Experiences with a New Fusion Welding Process for Thin Metal Sheets [of Light Metal Alloys] [Erfahrungen mit einem neuen Schmelzschweissverfahren für dünne Bleche], by Dr. -Ing. E. von Rajakovics. Maschinenbau der Betrieb, Vol. 18, No. 15/16, Aug 1939, pp. 395-397. Translated by R. Widmer. Unpublished. 7 pp., 13 figs. Reference copy availate in TMB Library. Library.

179. On the Sensitization of Polyvinyl Alcohol As a Coating Material or Agent for the Fabrication of Plates for Printing [Über die sensibilisierung von Polyvinylalkohol als Beschichtungsstof f für die Herstellung von Druckplatten], by J. Albrecht. Kollo1d-Ze1tschr1ft, Vol. 103, No. 2, 1943, pp. 160-170. Translated by F.A. Raven. Unpublished. 7 pp., 6 figs. Reference copy available in TMB Library.

180. Contribution to the Theory of Stab1lity on Course and Steering Under Way [Be1trag zur Theorie der Kursstab1lität und der Steurfahrt], by Georg Welnblum. Schiffbau, Schiffahrt und Hafenbau, Vol. 38, No. 4, 1937, pp. 57-58. Translated by F.A. Raven. Unpublished. 19 pp., 8 flgs. Reference copy available in TMB Library.

181. Documentation [Dokumentation]. VDI-Zeitschrift, Vol. 88, No. 9/10, 4 Mar 1944, pp. 125-126. Translated by R. Widmer. Unpublished. 9 pp. Reference copy available in TMB Library.

182. Launching Tests w1th Two Sh1p Models [Stapellaufversuche mit zwe1 Sch1ffmodellen], by D1p1.-Ing. Henry Stemmer. Schiffbau, Schiffahrt und Hafenbau, Vol. 38 , No. 12, 15 Jun 1937, pp. 197-200, No. 13, 1 JuI 1937. pp. 217-219. Translated by F.A. Raven. Unpublished. 12 pp., 7 figs. Reference copy available in TMB Library.

183. Investigation of the Change of Resistance in W1res Produced by Tension [Untersuchungen über die W1derstandsänderung von Drähten durch Zug], by E. Czerlinsky. Report of the German Research Institute for Aeronautics [Jahrbuch der Deutschen Luftfahrtforschung, 1938, Vol. 2, pp. 377-380. Translated by F.A. Raven. Unpublished. 10 pp., 4 flgs. Reference copy available in TMB Library. 
184. On the Separation of Eddies or Vortices and Its Prevention [über Wirbelablösung und deren Verhinderung], by Dr. L. Prandtl and Dr. A. Betz. Ergebn1sse der Aerodynamischen Versuchsanstalt zu Göttingen, 3rd Ed., 1927, pp. 6-9. Translated by F.A. Raven. Unpublished. 5 pp., 5 flgs. Reference copy available in TMB Library.

185. Ship Model Tests in the C1rculating Water Channel [Sch1ffsmodellversuche Im Strömungsgerinne], by Dr.-Ing. Hans Mueller. Schiffbau, Schiffahrt und Hafenbau, Vol. 37, No. 10, 25 May 1936, pp. 168-173. Translated by F.A. Raven. Unpubl1shed. Rough draft in TMB translation file.

186. Resistance of a Cylindrical Tube of Infinite Length, Closed at Eoth Extremities and Filled with Water under Pressure or Immersed in Water, Its Generating Lines Being Horlzontal and Its Transverse Section HavIng a Vertical Axis of Symmetry [Résistance d'un tube cylindrique de longueur infinie, fermé a ses deux extrémités et rempli d'eau sous pression ou immergé dans l'eau, les generatrices etant horizontales et la section transversale ayant un axe de symmetrie vertical], by $M$. Simonot. Bulletin de I'Association Technique Maritime, Vol. 20, 1909, pp. 247-263. Translated by F.A. Raven. Unpublished. 14 pp., 3 flgs. Reference copy available in TMB Library.

187. The Elin-Hafergut Method for Welding of Thin Metal Sheets [Das ElinHafergut Verfahren für die Dünnblechschwelssung], by H. Hauser. Bulletin Schweizerische Elektrotechnische Verein, Vol. 19, 1943, pp. 566569. Translated by R. Widmer. Unpublished. 8 pp., 9 flgs. Reference copy available in TMB Library.

188. Erosion and Cevitational Erosion [Erosion und Kavitations-Erosion], by P. de Haller. Handbuch der Werkstoffprürung, Vol. 2, Die Prüfung der Metallischen Werkstoffe, Julius Springer, Berlin, 1939, pp. 471-488. Translated by R. W1dmer Apr 1951. 30 pp., 23 figs.

189. Memoir on the Calculation of the Fatigue Strength of Submarine Hulls [Note sur le calcul des fatigues des coques de sous-marins], by Henry Lecoq. Bulletin de I'Assoclation Technique Maritime et Aéronautique, Vol. 29, 1925, pp. 59-74. Translated by F.A. Raven. Unpublished. 14 $\mathrm{pp} ., 10 \mathrm{flgs}$. Reference copy available in TMB Library.

190. The AEQ Light-Flash Stroboscope [Das AEG-L1chtblitzstroboskop], The AEQ Spark-Flash Apparatus FG6/1 [Das AEG-Funkenblitzgerät FG6/1], AEG Report. VDI-Ze1tschr1ft, Vol. 87, No. 27/28, 10 Jul 1943, back cover; No. $39 / 40,2$ oct 1943, back cover. Translated by F.A. Raven. 2 pp. Reference copy available in TMB translation file.

191. Report of the Germaniawerft Respecting Explosion or Blast Tests on Hatch Seal Locks [Erklärungen der Germanlawerft zu den Sprengversuchen an Lukenverschiüssen]. United States Naval Techn1cal Mission in Europe in 1944. Translated by F.A. Raven. Unpublished. 10 pp., 13 flgs.

Reference copy available in TMB translation file. 


\section{TRANSLATIONS}

192. A Nonlinear Boundary-Value Problem - Forced Pendulum Oscillations [E1ne nichtlineare Randwertaufgabe - Erzhungene Pendelschwingung], by $A$. Hammerstein. Jahresbericht der Deutschen Mathemat1ker Vereinigung, Vol. 39, 1930, pp. 59-63. Translated by F.A. Raven. Unpublished. 6 pp. Reference copy available in TMB Library.

193. Theory of Stationary Compression Shock [Zur Theorie des stationären Verdichtungsstosses], by F. Schubert. VDI-Ze1tschr1ft, Vol. 87, No. 51/ 52, 25 Dec 1943. Translated by R. Widmer. Unpublished. 3 pp., 7 figs. Reference copy available in TMB Library.

194. Scale Effect and Its Determination in Ship Model Tests [El efecto de escala y la determinación de ésta en los ensayos con modelos de buques], by Manuel L. Acevedo. La Rev1sta Ingenleria Naval, 1943, pp. 518-532. Translated by F.A. Raven. Unpublished. 23 pp., 6 figs. Reference copy available in TMB Library.

195. Canceled.

196. Tests at Guidonia Model Basin on Electrically Propelled Aerial Torpedo F.F.F. 120-500-360 (Esperienze Alla Vasca Idrodinamica Di Guldonia Sulla Motobomba) Ministero Dell'Aeronaut1ca Direzione Superiore Degli Studi e Delle Esperienze I Divisione - Aeromobili ed Aerodinamica Report No. 236. Translated by F.A. Raven, Ph.D. Sep 1950. 12 pp., 12 figs.

197. On Submerged Navigation of Submarines under Diesel Fower [Per la navigazione del sommergibili in immersione col Motori Diesel], by $P$. Ferrett1. Istituto di Guerra Marit1ma Sviluppo del Materiale Bellico. Translated by F.A. Raven. Unpublished. 31 pp., $19 \mathrm{flgs}$. Reference copy available in TMB Library.

198. Theoretical Investigations on Cooling of Gas Turbines [Theoret1sche Untersuchungen über Kühlung von Gasturbinen], by K.J. Müller. Deutsche Luftfahrtforschung, Forschurigsbericht No. 1918, Published by Deutsche Versuchsanstalt für Luf'ifahrt E.V., Institut fir Stromungsmaschinen, Berlin-Adlershof. Zentrale fir wissenschaftliches Berichtswesen der Luftfahrtforschung des Generalluftzeugmeisters ( $Z$ W B), Berlin-Adlershof. Translated by F.A. Raven. Mar 1946. 34 pp., 23 flgs.

199. Production Increase in Nava? Construction by Improved and Modernized. Welding Methods (Lelstungsstelgerung im Kriegssch1ffoau durch Neuzeitliche Schweissverfahren). Report given under direction of K. Malisius of the German Navei High Command. Report No. 4 of Industrial Convention held at Finsterwalde-NL, 25 and 26 November 1943. $196 \mathrm{pp}$. Digest of translation by F.A. Raven, Ph.D. Unpublished. (Typed copy in TMB translation file).

200. The General Principle of Similitude in Physics and Its Relation to the Theory of Dimensions and the Science of Scale Models [Das allgemeine Ahnlichkeitsprinzip der Physik und sein Zusammenhang mit der Dimensionslehre und der Modellwissenschaft], by Prof. Dr.-Ing. Moritz Weber. Jahrbuch der Schiffbautechnischen Gesellschaft, Vol. 31, 1930, pp. $274-354$. Translated by F.A. Raven. Unpublished. Typed copy in TMB translation file. 
201. Canceled.

202. Stability of Ships in Operation [Die Stabilităt des Schiffes im Betrieb], by Dipl.-Ing. E. Klindwort. VDI-Ze1tschrift, Vol. 87, No. 23/ 24, 12 Jun 1943, pp. 359-365. Translated by R. Widmer. inpublished. $18 \mathrm{pp} ., 5 \mathrm{figs.}$ Reference copy available in TMB Library.

203. Characteristic Curves for Breakage Radius of Window Glass Caused by Bomb Blasts [Zerstörungskennlinien von Fensterglas], by Dr.-Ing. Geppert. Ballistisches Institut der Technischen Akademie der Luftwaffe, Berlin-Gatow, 1944. Translated by R. Widmer. Unpublished.
Rough draft in TMB translation file.

204. Stereophotogrammetric Wave Photographs [Stereophotogrammetrische Wellenaufnahmen $]$, by Georg Weinblum and Walter Block. Jahrbuch der Schiffbautechrischen Gesellschaft, Vol. 37, 1936, pp. 214-250 and 259-276. Translated by F.A. Raven. Nov 1949. 79 pp., 47 figs.

205. Canceled.

206. Canceled.

207. The Eigh-Speed Spark Camera [Die Funkenzeitlupe], by Dr. Alfred Ke11. Translated by R. Widmer. Sep 1947. 13 pp., 7 figs.

208. Classified.

209. Oscillation of the Gas Globe in an Underwater Explosion [Die Gasblasenschwingung bel einer Unterwassersprengung], by Alfred Keil and Walter Wunderlich. Chemisch-physikalische Versuchsanstalt der Marine. Paper obtained in manuscript form by the United States Naval Technical Mission in Europe in 1944. Translated by R. Widmer. Oct 1947. 51 pp., 17 figs.

210. Canceled.

211. Measurement of Deflection Curves on Aircraft and Ships [Biegelinienmessung an Flugzeugen und Schiffen], by Dr.-Ing.H.G. Kussner. Paper obtained in manuscript from by the United States Naval Technical Mission in Europe in 1945. Translated by R. Widmer. Mar 1949. 22 pp., 6 figs.

212. Measurements on a Model of a Jet-Propulsion Nacelle [Messungen an dem Modell Einer Strahlantriebsgondel], by Brennecke. Deutsche Luftfahrtforschung Forschungsbericht No. 1723, Aerodynamischen Versuchsanstalt zu Gottingen, Jan 7, 1943. Translated by C.J. Wenzinger. Oct 1046. 27 pp., 6 figs. 
213. Measurements on Shock Waves in Water with the High-Speed Spark Camera [Messungen an Stosswellen in Wasser mit der Funkenzeitlupe], by Dr. A. Keil. Dänisch-Nienhof, Jul 1946. Translated by R. Widmer. Sep 1947. 29 pp., 15 figs.

214. Calculation for the Design of Oppositely Rotating Propellers or ContraPropellers [Rechenschema zum Entwurf Gegenläufiger Treibschrauben]. Report 906, Hamburg Model Basin. Translated by F.A. Raven. Unpublished. 3 pp., 1 fig. Reference copy available in TMB Library.

215. Development of Parachutes for Bombs, Mines, and Torpedoes [Entricklung von Fallschirmen fur Bomben, Minen, und Torpedoes], by Dr.-Ing. Helmut Heinrich. Research Institute Graf Zeppelin Stuttgart-Ruit. Translated by R. Widmer. Jan 1049.48 pp., 44 figs.

216. Report on the New Towing Carriage of the Hannover Model Basin [Bericht uber die neue Schleppvorrichtung der hannoverschen Versuchsanstalt], by Rudolf Eikenroth. Mitteilungen hannoverschen Hochschule Gemeinschaft, No. 16, 1935, pp. 14-16. Translated by Martin A. Mason. Unpublished. 4 pp., 5 figs. Reference copy available in TMb Library.

217. Wind-Tunnel Investigations of Jet Propulsion Models with Cold Jet [Windkanaluntersuchungen an Strahltrlebwerkmodellen mit Kaltem Strahl], by W. Lehmann. Deutsche Luftfahrtforschung Forschungsbericht No. 1902/1. Arado Flugzeugwerke, Brandenburg/Havel, 4 Nov 1943. Translated by C.J. Wenzinger. Dec 1946. 26 pp., 12 figs.

218. Wind-Tunnel Measurements of a Jet-Propulsion Model with Cold Jet and a Wing As a Boundary [Windkanalmessungen an Einem Strahltriebwerkmodell mit Kaltem Strahl und Einem Flügel als Blende], by W. Lehmann. Deutsche Lufteahrtforschung Forschungsbericht No. 1902/2. Arado Flugzeugwerke, Brandenburg/Havel, 4 Nov 1943. Translated by C.J. Wenzinger. Jan $1947.19 \mathrm{pp}$., 17 figs.

219. On the Use of Jet Drives for Wind Tunnels of High Velocity [über die Verwendung des Strahlantriebes bei Windkanalen Hoher Geschwindigke1t], by $\mathrm{H}$. Winter. Deutsche Luftfahrtforschung Forschungsbericht No. 1103 Aerodynamische Versuchsanstalt Gottingen e.V., 7 oct 1939. Translated by C.J. Wenzinger. Apr 1947. 25 pp., 8 figs.

220. Pressure Distributions over Bodies of Revolution for Axial Flow [Druckvertellungen von Rotationskorpern be1 Achsialer Anströmung], by $M$. Brand. Aerodynamische Versuchsanstalt Gottingen e.V., UM No. 3206 , 30 Dec 1944. Translated by C.J. Wenzinger. Apr 1947. 49 pp., 74 figs.

221. Luminous Living Organisms [Les êtres vivants lumineux], by C. Puissegur. Sclence et Vie, Vol. 70, No. 348, Sep 1946. Translated by R. Widmer. May 1947.17 pp., 9 figs. 


\section{TRANSLATIONS}

222. Study of Turning Tests at the Paris Model Basin [L'Etude de la Giration au Bass in D'Essais des Carenes], by J. Bleuzen, Ingenieur du Genie Maritime. Assuciation Technique Maritime et Aéronautique, June 1946. Translated by R. Widmer. Sep 1949. 21 pp., 7 figs.

223.

224. Some Remarks on Stationary Schemes for Cavitation Flow about a Flat Plate [Nekotorye Zamechanila o Statsionamykh Skhemakh Kavitatsionnogc Obtekanila Plastinki], by M.I. Gurevich. Izvestî̉a Akademî̉a Nauk, USSR, Otdelenie Tekhnicheskikh Nauk, 1947, No. 2, pp. 143-150. Translation and comments by J.V. Wehausen. Nov 1948. 19 pp. , 17 figs.

225. Experimental Method for Determining the Virtual Mass for Oscillations of Ships [Eine Experimentelle Methode zur Bestimmung der Reduzierten Masse des Mitschwingenden Wassers be1 Schiffschwingungen], by J.J. Koch. Ingenleur-Archiv, Vol. IV, Part 2, 1933, pp. 103-109. Translated by Georg Weinblum. May 1949.17 pp., 13 figs.

226. The Elastic Stresses in Thin-Walled Tubes Caused by Internal Pressures Created by Explosions [Die Elastischen Spannungen In Dunnwandigen Rohren unter Explosionsartigem Innendruck], by Karl Klotter and Ruth Pich. Prepared at the request of the Arbeitsgemeinschaft fiur Stossforschung by the Vierjanresplan-Institut für Schwingungsforschung, 1ssued by the Antsgruppe Mar Rüst/FEP ir the OKM, Research Report No. 58, Berlin, 14 December 1944. Translated by E.N. Labouvie. Jul 1949. 27 pp., 2 figs.

227. Measurement of the Pitch-Damping Moment of the Submarine V-80 -- An Experimental Method of Determining the Dynamic Stability of a Model of the Midget Submarine V-80 [Messung der Kippdampfung des Bootes V-80], by Braun. LuI'tfahrtforschungsanstalt Hermann Göring Institut für Aerodynamik. Translated by W.B. Hinterthan. Dec 1949. 12 pp., 11 figs.

228. Stress Distribution in the Flanges of Curved $T$ and I Beams [Die Spannungsverte1lung in den Gurtungen gekrümmter stäbe mit T- und I- förmigem Querschn1tt], by Hans Ble1ch. Der Stahlbau, Bellage zur Zeitschrift "Die Bautechnik," Vol. 6, No. 1, 6 Jan 1933, pp. 3-6. Translated by E.N. Labouvie, Jan 1950, 12 pp., 10 flgs.

229. Canceled.

230. Cavitation on Marine Propellers and its Prediction Based on the Results of Tests with Profiles (Cavitacion en propulsores marinos y su prediccion mediante resultados de ensayos con perfiles), by Manuel L. Acevedo, Naval Engineer. Report read by the author at the 3rd Convention of Naval Engineering Session of 9 Nov 1948. Translated by E.N. Labouvie. Jan 1951. 51 pp., 28 figs. 
TRANSIATIONS

231.

232. Investigations of Pitching (Recherches Sur Le Tangage), by Roger Brard. Association Technicue Maritime et Aeronautique - Session Jun 1945. Translated by E.N. Labouvie. Sep 1951. 27 pp., 20 figs.

233. Influence of Reynolds Number on the Separation (Cavitation) Flow (Vliianie Chisla Reinoldsa na Otryvnoe Obtekanie), by V.A. Konstantinov, Izvestiia Akademii Nauk USSR, Otdelenle Tekhnicheskikr Nauk 1946, No. 10, pp. 1355-1373. Translated by G. Weinblum. Nov 1950. $22 \mathrm{pp} ., 15$ figs.

234. Tests on Wave Resistance of Immersed Bodies of Revolution [Versuche uber den Wellenwiderstand Getauchter Rotationskorper], by G. Weinblum, H. Antsberg and W. Bock, Berlin. Mittellungen der Preussischen Versuchsanstalt fur Wasserbau und Schiffbau, Berlin, 1936. Translated by G. Weinblum and R. WIdmer. Sep 1950. 24 pp., 20 figs.

235. CIASSIFIED.

236.

237 .

238. The Elasticity Problem for Thin Shells of Toroldal, Spherical or Conclal Shape (Das Elastizltatsproblem fur dunne Schalen von Rimgflachen-, Kugel - oder Kegelform), by Ernst Meissner. Physik Zeitschr. XIV, 1913. pp 343-349. Translated by Wm. A. Nash. JuI 1951. $17 \mathrm{pp} ., 1 \mathrm{fig}$. 
230. Seving of Power in Formation Flying (Leistungsersparnis im Verbadsflug), by H. Schlichting. Bericht des Aerodynamisches Institutes der Technischen Hochschule Braunschwe1.5, No. 42/6, 15 June 1942. Translated by I. Pollin. Apr 1951. 41 pp., 24 figs.

240. Formation Flying in Stepped-Up Formation (Verbandsflug mit Hohenstaffelung), by $\mathrm{H}$. Schlichting. Bericht des Aerodynamisches Institutes der Technischen Iochschule Braunschwe1g, No. 44/7, 15 February 1944. Translated by I. Pollin. Oct $1950.25 \mathrm{pp} ., 9$ fies.

241. The Method of Singularities for the Determination of Forces and Moments Acting on a Body in Potential Flow (Singularitaetenverfahren zur Ermittlung der Kraefte und Momente auf Koerper in Potentialstroemungen), by A. Betz Góttingen. Ingenleur-Archiv. 1,932. Translated by M. St.Denis. Rev. Ed. Jun 1951. 13 pp., 21 figs.

242. Contribution to the Calculation of Turbulent Boundary Layers (Beitrag zur Berechnung der Turbulenten Grenzschichten), by J. Rotta. Report issued by the Max-Planch-Institut für Strömungsforchung in Göttingen; July 1, 1950. Translated by E.N. Labouvie. Nov 1951. 27 pp., 10 figs.

243. The Present Status of Theoretical Research on Ship Propellers with Respect to its Techical Application (Der Stand der Forschung Über den Schiffspropeller Im Hinblick auf die Technische Berechnung), by Dr. Ing. H. Lerbs. Werft-Reecere1-Kafen, Vol. 23, 15 February 1942, pp. 57-62. Translated by E.N. Labouvie. Jen 19,52. 21 pp., 4 figs.

244. Resistance and Fropulsion of Motorboats (Weerstand En Voortstuwing Van Motorboten), by D. DeGroot. Publication No. 93 of the Model Basin in Waceningen. Translated by W.B. Hinterthan. Jan 1056. 39 pp., 16 figs.

245. The Influence of the Boundary Layer on the wave Resistance of a Ship (Vlianie Pogranichnoe Sloia na Volnovoe Soprotivlene Korablia), by V.M. Iavrentieff, Central Scientific Research Institute of the Maritime Fleet, Reports of the Academy of Sclences of the U.S.S.R. 1551, VoI. IXXX, No. 6. Translated by Ralph D. Cooper. Apr 1952. 8 pp., 1 flg.

246. Collected French Papers on the Stability of Route of Ships at Sea, 1049-1550, by Jean Dieudonne, Director, The Institute of Research in Naval Construction, Paris. Translated by Capt. H.E. Saunders, USN, and E.N. Labouvie, Ph.D. Jan 1953. 66 pp., 14 flgs.

247 . 
$21: 8$.

240. Canceled.

250 .

251 .

252.

253. A Method of Determining the Pitching and Heaving Characteristics of Ships, by M.D. Haskind and I.S Riman. Bulletin de I'Academie des Sciences de J.'URSS Classe des Sciences Techniques, 1046. Translated by $\mathrm{E}$. Weiner. Feb 1055. 17 pp., 14 figs.

254.

255.

256.

257. Optimum Location of the Center of Buoyancy of Merchant Ships (cunstigste

Lage des Verdrängungsschwerpuniktes von Handelsschiffen), by Prof.

Völker, D. Eng., Schiff und Eafen, Vol. 5, Mar 1953, No. 3. Translated by I.N. Labouvie, Ph.D. Aug 1055. Q pp., $5 \mathrm{flgs.}$ 
258. The Resistance Law for Rough Plates (Das Widerstandsgesetz Rauher Platten), by L. Prandtl and H. Schlichting, Werft-Reedere1-Hafen, Vol. 15, January 1934, No. 1. Translated by P.S. Granvilie. Sep 1955. 15 pp., 4 flgs.

259. Cavitation of Surface Roụhnesses (Kavitats1ya Nerovnostey Poverkhnosti), by K.K. Shelnev, Journel. of Applied Physics, USSR, Vo1. 21, No. 2, 1551, pp. 206-220. Trunslated by R.D. Cooper. Dec 1955. 27 pp., 10 figs.

260. Hydrodynamic Masses and Eydrodynemic Moments of Inertie. (Hydrodynamische Vessen und Hyärodynemische Massenträgheitsmomente), by Dr. Eng. Kurt Wendel. Jehrb. d. STG, Vol. 44, 1950. Translated $\mathrm{ky}$ E.N. Labouvie, Ph.D. and Avis Eorden, Ph.D. Jul 1956. 84 pp., 50 flgs.

261. (Contract NPS 8331). On the Determination of the Equilibrium States of a Circular Shell Under Axially-Symetric Loading, by N.A. Alunyae. Frikladnaya Matem. 1 Mekh., Vol. 17, pp. 517-528, 1953. Translated from Russian by Dr. George Herrmann. Mar 1956. $27 \mathrm{pp.,} \mathrm{no} \mathrm{figs.}$

25?. (Contract NPS 8331). The Letermination of Large Deflections of a Cylindricel Panel, Resting on Flexjble, Inextensible Ribs, Suhjected to Extermel Norma? Loadine, by Kh. M. Mushtari, I.V. Svirski. Prikiadnaya Matem. i llekh., Vol. 17, pp. 755-760, 1953. Translated from Russian by Ir. George Eerrmenn. Mar 1s56. 14 pp., no figs.

263. (Contract NPS 8331). On tre Theory of Stability of a Spherical Shell Sujiected tc External Pressure (with reference to the paper by V.I. F'eodos'ev (1)), by Kh. M. Mushtarl. Prikladnaya Matem. 1 Mekh., Vol. 19, pp. 251-254, 1955. Translated from Russian by Dr. George Eerrmann. Mar 1956. $12 \mathrm{pp}$. no figs.

264. (Contract NPS 8331). On the Analysis of Shells Subjected to Concentrated Loads, by A.I. Goldenvelzer. Prikladnaya Matem. i Mekh., Vol 18, pp. 181-186, 1954. Translated from Russian by Dr. George Eerrmann. Mar 1956. $15 \mathrm{pr}$. no figs.

265. (Contract NiPS 8331). On the Stability of a Closed Two-Layered Conical Shell, Subjected to Uniform Normal Pressure, by E.I. Grigolyuk. Inzhererny Sborn1k, Vol. 19, pp. 73-82, 1954. Translated from Russtan by Dr. George Eerrmann. Mar 19,56. 17 pp., 1 flg.

266. (Contract NPS 8331). On the Stability of a Spherical Shell, Subjected to the Action of External Hydrostatic Pressure, by V.I. Feodos'ev. Prikladnaya Matem. 1. Mekh., Vol. 18, pp. 35-42, 1554. Translated from Russian by Dr. George Herrmann. Mar 1956. 16 pp., 3 figs. 


\section{TRANSLATIONS}

267. (Contract NPS 8331). On a Case of Pre-Critical State of Eending of a Cjlindrical Shell, by N.A. Alfutov. Prikladnaya Matem. i Mekh., Vol 19, pp. 249-250, 1955. Translated from Russian by Dr. George Herrmann. Mar 1956. $7 \mathrm{pp} ., 1 \mathrm{fig}$.

268.

269.

270. Excitation of Resonance by Air Flow (Vozbuzhdenie Rezonatorov Potokom Vozdukha), by D.I. Blokhnitsev. ZhTF, Vol. XV, pp. 63-70 (1945). Translated by R.D. Cooper. Jan 1957. 13 pp., 6 figs. 


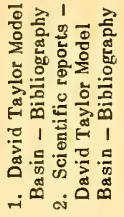

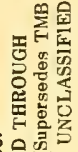

ถํㅜ원

占通

$\propto$

z品:

दू,

少

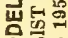

울용

옹솔

霖骂

战四

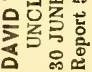

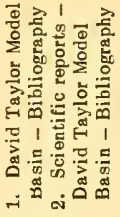

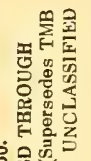

옹

岛

능

玄究㐫

品。

㟧舟总

오교

영

통

这罂的

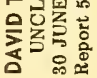

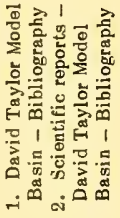

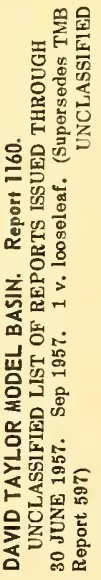

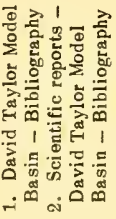

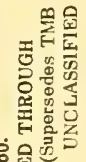

응욍

七陨

恶

몽 8

兖淟新

品:

岀昆

욱응

송

올

这罂:

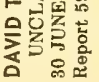



